Policy Research Working Paper 2333

Output Fluctuations

in Latin America

\section{What Explains the Recent Slowdown?}

Santiago Herrera

Guillermo Perry

Neile Quintero
For the period 1992-98.

domestic factors explain most

output variability in Latin

America. However, external

factors account for about 60

percent of the 1998-99

slowdown - perhaps in part

because external veriables

were more volatile during this

period, but mainly because

domestic variables - real

interest rates and real

exchange rates - were more stable in these two years.

The World Bank

Latin America and Caribbean Regional Office

Economic Policy Sector Unit

and

Poverty Reduction and Economic Management Sector Unit

May 2000 


\section{Summary findings}

Herrera, Perry, and Quintero explain Latin America's growth slowdown in 1998-99. To do so, they use two complementary methodologies.

The first aims at determining how much of the slowdown can be explained by specific external factors: the terms of trade, international interest rates, spreads on external debt, capital flows, and climatological factors (El Niño). Using quarterly GDP data for the eight largest countries in the region, the authors estimate a dynamic panel showing that 50-60 percent of the slowdown was due to these external factors.
The second approach allows for effects on output by some endogenous variables, such as domestic real interest rates and real exchange rates. Using monthly industrial production data, the authors estimate country-specific generalized vector autoregressions (GVAR) for the largest countries.

They find that during the sample period (1992-98) output volatility is mostly associated with shocks to domestic factors, but the slowdown in the subperiod 1998-99 is explained more than 60 percent by shocks to the external factors.

This paper - a product of the Economic Policy Sector Unit and the Poverty Reduction and Economic Management Sector Unit, Latin America and Caribbean Regional Office - is part of a larger effort to understand output fluctuations and growth in the region. Copies of the paper are available free from the World Bank, $1818 \mathrm{H}$ Street NW, Washington, DC 20433. Please contact Cristina Palarca, room 18-165, telephone 202-473-5328, fax 202-522-2119, email address cpalarca@worldbank.org. Policy Research Working Papers are also posted on the Web at www.worldbank.org/research/ workingpapers. The authors may be contacted at gperry@worldbank.org or nquintero@worldbank.org. May 2000. (62 pages)

The Policy Research Working Paper Series disseminates the findings of work in progress to encourage the exchange of ideas about development issues. An objective of the series is to get the findings out quickly, even if the presentations are less than fully polished. The papers carry the names of the authors and should be cited accordingly. The findings, interpretations, and conclusions expressed in this paper are entirely those of the authors. They do not necessarily represent the view of the World Bank, its Executive Directors, or the countries they represent. 


\title{
Output Fluctuations in Latin America: What Explains the Recent Slowdown? ${ }^{1}$
}

\author{
Santiago Herrera \\ Guillermo Perry \\ Neile Quintero
}

\begin{abstract}
The object of the paper is to explain Latin America's growth slowdown experienced in 1998/99. To do so we used two complementary methodologies. The first one aimed at determining how much of the slowdown could be explained by specific external factors, namely, the terms of trade, international interest rates, spreads on external debt, capital flows and climatological factors (El Nino). Using quarterly GDP data for the 8 largest countries of the region, we estimate a dynamic panel that allowed to calculate that between $50 \%$ and $60 \%$ of the slowdown was due to the role of these external factors. The second approach allows for the role of some endogenous variables, like domestic real interest rates and real exchange rates, to affect output. Using monthly industrial production data, we estimate country-specific Generalized Vector Autoregressions (GVAR) for the largest countries. We found that during the whole sample period (19921998) output volatility was mostly associated with shocks to domestic factors, but the slowdown in the sub-period 1998-1999 was explained in more than 60\% by the external factors' shocks.
\end{abstract}

\footnotetext{
${ }^{1}$ This paper is a modified version of the presentations in the Latin America Round Table Conference, Duff and Phelps, New York, April 15, 1999 and in the Harvard Institute for International Development The authors acknowledge and thank excellent research assistance by Conrado Garcia and Bernadette Ryan. Comments by Eliana Cardoso, Daniel Lederman, Deepak Mishra and Luis Serven are gratefully acknowledged.
} 
..

$-$. 


\section{Introduction and Summary}

During 1997-1999, Latin America was subject to external and internal shocks of sizable magnitudes. Consequently, the region's growth rate in 1999 was negative for the first time since 1983. Among the external shocks, the most notable were associated with sudden stops in capital flows and terms of trade deterioration. On the internal side, real interest rates and 1 al exchange rates adjusted both endogenously in response to external shocks and as a result of shifts in domestic factors such as policy variables. How do these variables interact with output fluctuations in Latin America, and in particular, what is their relative importance in terms of explaining the 1998-1999 slowdown?

To answer these questions, we used two complementary approaches. In the first one, we pooled quarterly data for the eight largest economies of the region and estimated panel regressions for regional GDP growth, considering as exogenous external factors the terms of trade, US real interest rates, non-Latin Brady bonds sovereign spreads, the current account of industrialized countries (as a proxy for exogenous capital flows) and an index of $\mathrm{El}$ Nino effect. The role of internal factors and other non-specified external variables was captured by means of the lagged value of GDP growth, which also subsumes dynamic effects in the panel. This simple approach has several advantages: first, it permits an assessment of the relative importance of external vs. domestic factors at the regional level; second, by allowing the disturbances of the equations to be related, it captures interdependence among countries' output fluctuations; finally, by pooling the data we minimize small sample problems. The simplicity of this method, however, comes with drawbacks such as the lack of flexibility for country-specific analysis and the absence of explicit treatment of domestic factors. To overcome these limitations we estimated country-specific VARs incorporating domestic real interest rates and real exchange rates as additional explanatory variables.

The paper is divided in three parts. The first section presents the quarterly GDP panel regression exercise used to determine the importance of external factors explaining the regional slowdown. Using quarterly data from 1992 to 1998 for the eight largest countries of the region, we estimated panel regressions, and using the 1997 exogenous external conditions as a benchmark, we found that at least $52 \%$ of the regional slowdown was due to the adverse behavior of external factors.

The second section summarizes the country-specific "stylized facts" about the relationship between events in the external capital markets ${ }^{2}$, terms of trade, domestic real interest rates, real exchange rates and industrial production growth, using monthly data

\footnotetext{
${ }^{2}$ To capture the external capital markets shocks we use the Brady Bond sovereign spreads provided by JP Morgan. In the last section of the paper we discuss the inclusion of this "price" variable instead of a "quantity" indicator.
} 
for the period 1992-1998. To capture the interaction among these variables we used the Generalized Vector Autoregression methodology (Koop, Pesaran and Potter, 1996). Contrary to traditional VAR analysis, this approach yields variance decompositions and impulse response functions independent of any specific ordering of the variables or any other restrictions imposed on the variance-covariance matrix of the reduced form VAR residuals.

Based on the generalized variance decompositions, we found that, for the whole sample period 1992-1998, the forecast error variance of output was explained primarily by shocks to domestic interest rates and the real exchange rate, which we labeled domestic factors. The notable exceptions were Argentina and Peru, where shocks to the external variables (terms of trade and spreads on sovereign debt) accounted for a large share of the variance relative tu the domestic factors' proportion. The dominance of internal factors explaining output volatility, is common to other papers (Ahmed (1999), Hausman-Gavin (1995), Hoffmaister and Roldos (1997).

On a country-by-country basis, we found that, during the seven years covered in our sample, shocks to external capital markets were a relatively more important source of output variability in Argentina, Brazil and Mexico, while in Ecuador Peru and Venezuela terms of trade shocks were the dominant explanatory factors of the output forecast error variance. This differential effect of the role of external factors contrasts with previous papers' results for the region as a whole according to which capital markets shocks dominate over the terms of trade shocks (Hoffmaister-Roldos, 1997) or vice-versa (Hausman-Gavin, 1995). In Chile and Colombia, domestic real interest rate shocks were the principal factors associated with output variability. Output variability was also associated with real exchange rate variability, specially in Brazil, Mexico and Colombia. In general, we found that a depreciating shock to the real exchange rate is associated with lower growth rates in the short run, as has been extensively documented for the region.

The third section concentrates on the sub-period 1997-1999 and on a sub-set of countries, to explain the slowdown in each of them. Based on the generalized impulse-response functions derived in the previous section and on the estimated historical shocks that affected each country during this sub-period, we found that external factors account for the greatest part of the slowdown. For Argentina, we calculated that external factors explain more than $60 \%$ of the slowdown in 1998-1999. In Brazil, the two major sources of slowdown were the spreads shocks and the real interest rate shocks. In this country the spreads shock had the largest impact on output. In Mexico the terms of trade and external spreads accounted for the major part of the slowdown, but in this case, as with Brazil, our models predicted a substantially larger slowdown than the one that actually occurred. In Chile and Colombia we estimated that shocks to domestic real interest rates were the main sources of contractionary pressure in 1998, but in 1999 the terms of trade, external spreads and the real depreciation explain most of the slowdown. 


\section{The Role of External Factors on the Regional Slowdown during 1998-1999}

A noticeable feature of regional output growth in 1998 and 1999 was the magnitude and persistence of the slowdown. Casual examination of quarterly GDP growth rates (Fig. 1) shows that the recent slowdown is more persistent than that experienced during the Tequila episode ${ }^{3}$. Regional GDP annual growth rates fell from $5.4 \%$ in 1997 to $2.3 \%$ in 1998 and to an expected $-0.3 \%$ in 1999 (Table 1). In 1998 and 1999 the eight largest Latin American economies experienced decelerations ranging from -13.5 to -2.8 percentage points. The 5.7\% regional slowdown experienced between 1997 and 1999 is only comparable, in magnitude, to the initial deceleration registered in 1982.

Figure 1

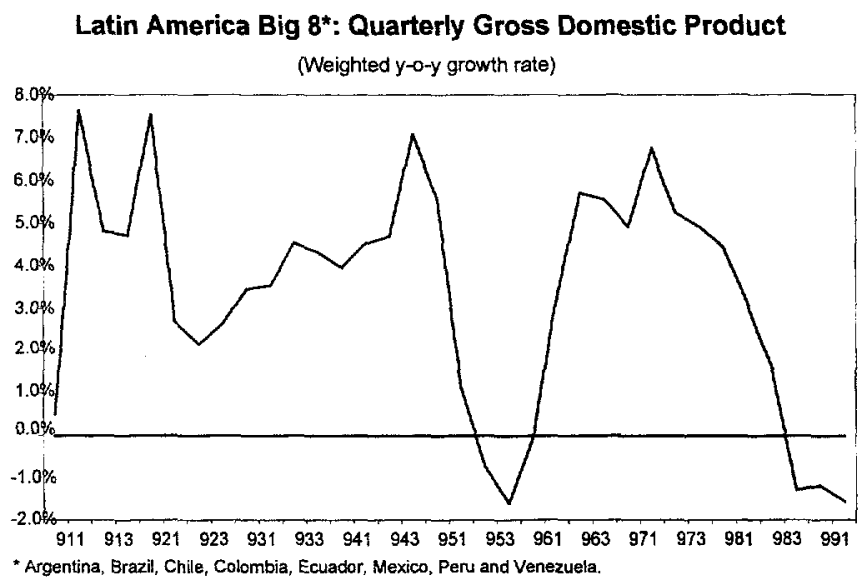

The widespread nature of the slowdown strongly suggests that common factors were at play, besides the particular domestic circumstances of each country. In this section we seek to quantify the relative importance of external factors vis-a vis the internal ones accounting for the regional slowdown during 1998-1999.

\footnotetext{
${ }^{3}$ Comparisons with the eighties using quarterly GDP data was not possible due to non-existent data. A more thorough examination of business cycles in Latin America during the eighties and the nineties, probably using monthly industrial output could be an interesting task, but falls beyond the scope of this paper.
} 
Table 1.

Latin American GDP Growth Rates

(in \%)

\begin{tabular}{lcccc} 
& \multicolumn{3}{c}{ GDP Growth } & Slowdown $^{3}$ \\
\cline { 2 - 4 } & 1997 & 1998 & $1999^{2}$ & $1999-1997$ \\
\hline Argentina & $\mathbf{8 . 1}$ & 3.9 & -4.0 & -12.1 \\
Brazil & 3.6 & 0.2 & 0.8 & -2.8 \\
Chile & 7.6 & 3.4 & -1.0 & -8.6 \\
Colombia & 3.0 & 0.6 & -4.5 & -7.5 \\
Ecuador & 3.4 & 0.4 & -7.3 & -10.7 \\
Mexico & 6.8 & 4.9 & 3.6 & -3.2 \\
Peru & 6.9 & 0.7 & 2.7 & -4.2 \\
Venezuela & 5.9 & -0.4 & -7.0 & -12.9 \\
\hline \multicolumn{2}{l}{} & & & \\
\hline Weighted Average & $\mathbf{5 . 4}$ & $\mathbf{1 . 8}$ & $\mathbf{- 0 . 2}$ & $\mathbf{- 5 . 7}$ \\
\hline
\end{tabular}

${ }^{1}$ Weighted by 1997 GDP.

${ }^{2}$ Forecasted for 1999 based on third quarter data

${ }^{3}$ Difference between 1999 and 1997 growth rates

The idea that common external factors are fundamental explanatory variables of macroeconomic outcomes in developing countries was revisited by Calvo et. al. (1993) who elucidated the resumption of international capital flows to Latin America in the early nineties based on the role of external factors. More recently, business cycle models have been extended to capture the role of external factors (Mendoza, 1995). However, the empirical literature has mixed results about the relative importance of domestic and external factors as sources of output volatility. On one hand, Hausman-Gavin (1995) conclude that domestic factors are the main cause of output volatility, and so do Hoffmaister and Roldos (1997) and Ahmed (1999) ${ }^{4}$. On the other hand, Joyce and Kamas (1997) show that the relative importance of each factor varies with the country. All these papers, except Ahmed's, have in common a sample period that covers, at the most, until 1994.

The prevailing external environment during 1998 and 1999 was very unfavorable for the region, as depicted by the evolution of regional terms of trade (Fig. 2) and the cost and availability of external financing ${ }^{5}$ (Fig. 3 and $3 \mathrm{~A}$ ). Additionally, some countries,

\footnotetext{
${ }^{4}$ Kamin-Babson show that the probability of currency crises in Latin America is determined fundamentally by internal factors. This result can be interpreted in favor of the domestic determinants of output volatility, given the association between currency crises and output growth.

S As a proxy for the cost of financing we include besides the real interest rate in the US, the non-Latin Brady bond sovereign spreads assuming it is completely exogenous to Latin America. In the following section we allow for endogeneity of the spreads. As a proxy for exogenous capital flows, to describe the availability of external financing, we use the current account of industrialized countries. In the last section we discuss the inclusion of both price and quantity variables of this market.
} 
particularly Ecuador and Peru, were negatively affected by the warming of the Pacific Ocean observed in 1998, caused by "El Niño" (Fig. 4$)^{6}$.

Figure 2

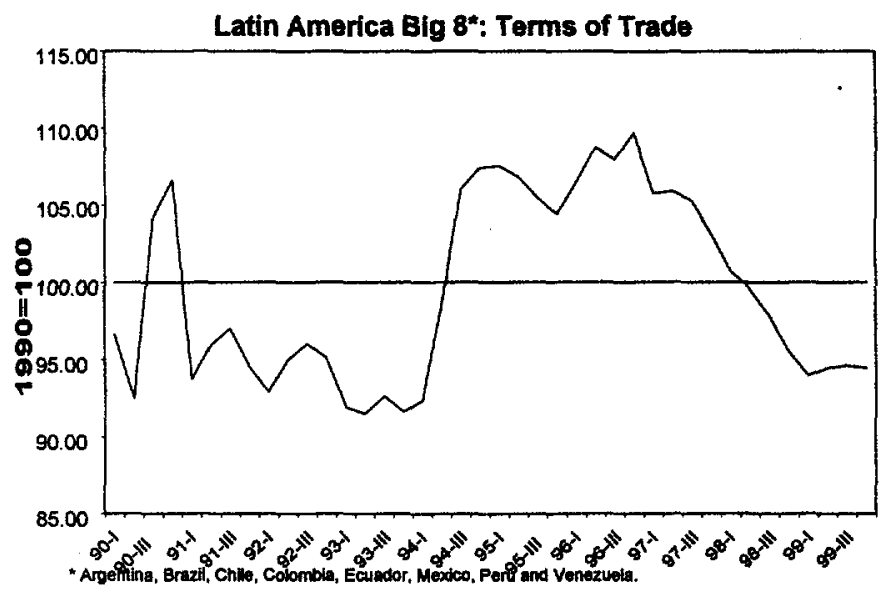

Fig. 3*

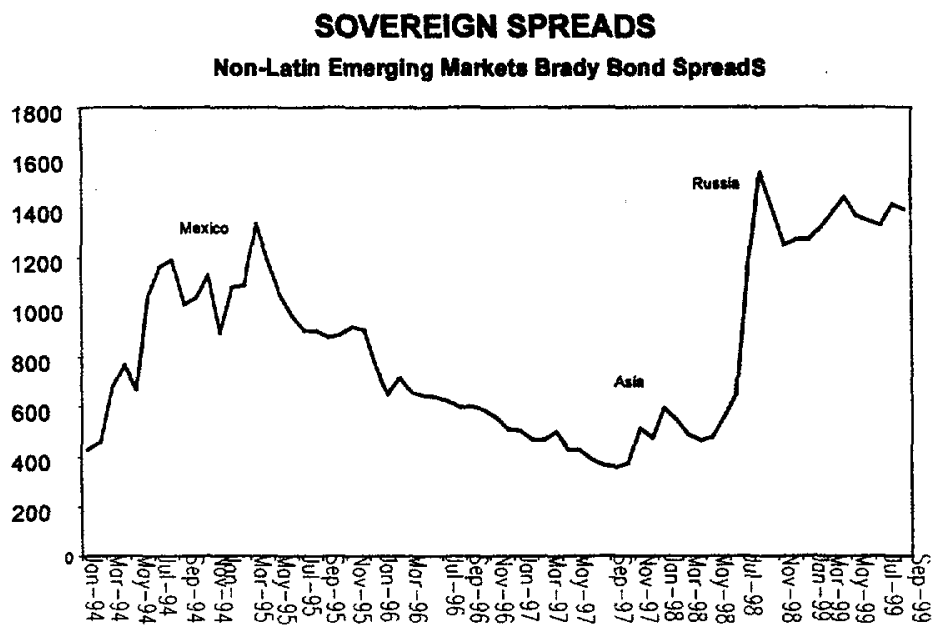

*Source JPMorgan

${ }^{6}$ The intensity of El Niño is captured by the Southern Oscillation Index (SOI), obtained from the Australian Commonwealth Bureau of Meteorology. The SOI is based on the monthly seasonal fluctuations in the air pressure difference between Tahiti and Darwin Sustained negative values of the Southern Oscillation Index (SOI) often indicate El Nifio episodes. 
Fig. 3A

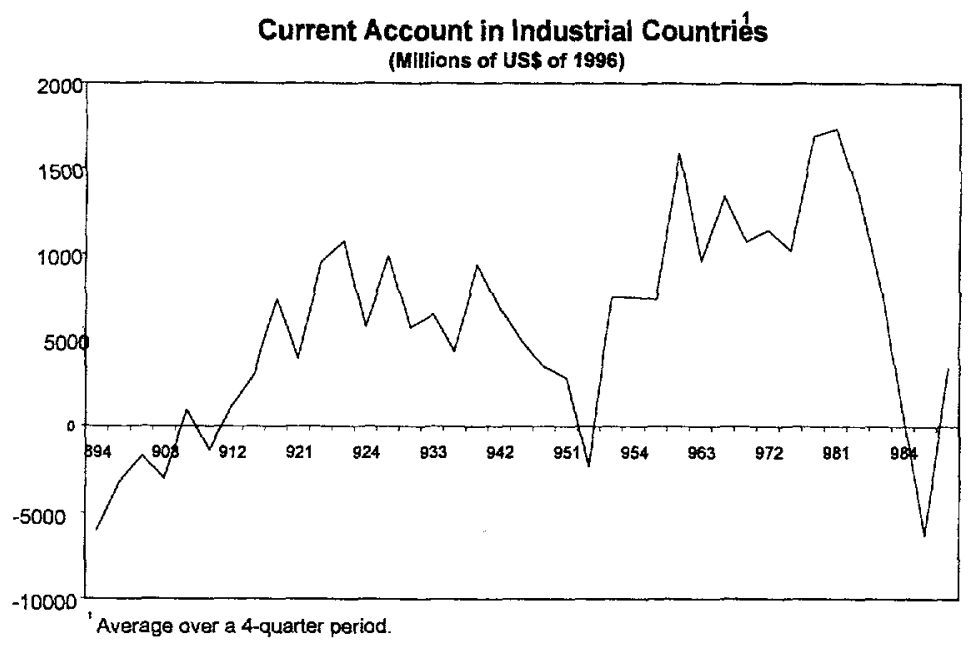

Fig. 4

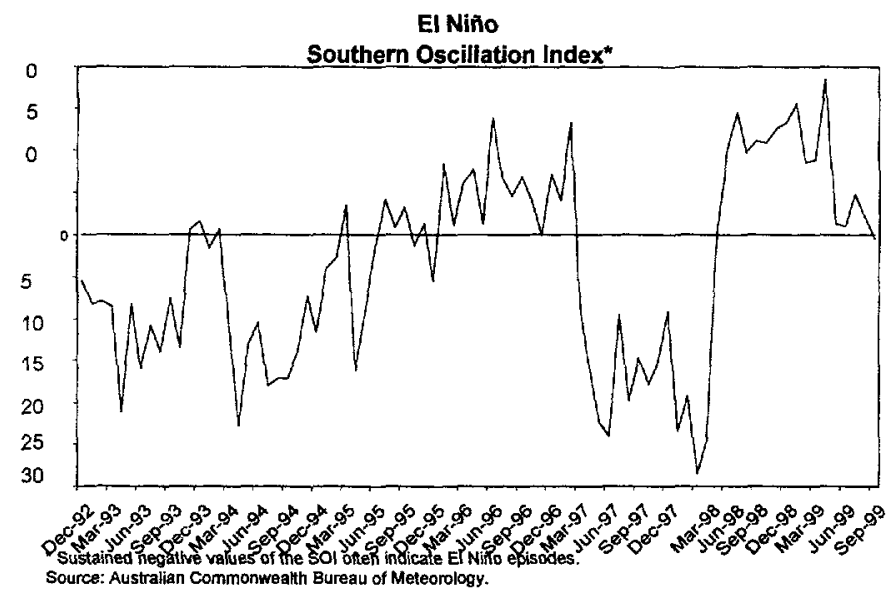

To measure the extent to which external developments accounted for the slowdown, we estimated an equation relating output growth to its own lagged value and a set of external factors ${ }^{7}$, using a dynamic panel data approach, estimated with Seemingly Unrelated Regressions (SUR) methods. This approach has several advantages: first, it allows derivation of general conclusions with respect to the impact of external factors on regional output fluctuations; second, with the SUR method we explicitly take into account "interdependence" among the countries in the group. SUR estimation will

\footnotetext{
${ }^{7}$ Listed in equation (1): Terms of trade, US real interest rate, current account balance of industrialized countries, non-Latin Brady bond sovereign spreads, and El Nino index. Initially we included US GDP but it turned out statistically insignificant. Ahmed (1999) gets similar results.
} 
increase efficiency given the expected contemporaneous correlation in the residuals of each equation ${ }^{8}$. Lastly, by pooling the data we minimize sample size problems.

The specification is as follows 9 :

$$
\begin{aligned}
& \Delta_{4} Y_{i t}=\sum_{l=1}^{m} \beta_{l} \Delta_{4} Y_{i, t-l}+\sum_{j=0}^{n} \alpha_{j} \Delta_{4} T_{O S T_{i, t-j}}+\sum_{j=0}^{p} \mu_{j} U S I_{t-j}+\sum_{j=0}^{p} \delta_{j} C A I_{t-j}+\sum_{j=0}^{q} \lambda_{j} \Delta_{4} S P D_{t-j} \\
& +\sum_{j=0}^{r} \omega_{j} I S O_{t-j}+C_{i}
\end{aligned}
$$

Where,

$Y_{i t}: \quad$ Output

TOT $T_{i t}$ : Terms of Trade

$U S I_{i t}:$ US Federal Funds real interest rate.

$\mathrm{CAI}_{t}$ : Current Account Industrial Countries (millions of US dollars at 1996 prices).

$S P D_{i t}$ : Non Latin Brady Bond Sovereign spreads.

$I S O_{i t}$ : Southern Oscillation Index.

$C_{i}$ : Constant term.

And,

$\Delta_{4}: \quad$ year-over-year variation

Subscript $i$ : $i$ th country

Estimation results (Appendix 1) show that coefficients are significant and with the expected sign: terms of trade improvements and better climatic condition (as measured by the ISO index) have a positive effect on growth whereas higher external interest rates and spreads have a negative effect, as does a lower availability of funds.

The estimated coefficients are then used to calculate 1998 and 1999 growth rates under two scenarios: Actual (external variables take actual values) and Constant (assuming external variables remain at their 1997 average level). That is, we estimate the N-step forecast under these two alternative external conditions, and the difference between the two is the effect of the external factors on growth. For the region as a whole, we calculate that external factors account for 4.6 percentage points of the slowdown (Table 2, Col. 3).

To calculate the total slowdown we use two alternative procedures: one possibility is to use the N-Step forecast using the actual conditions in the external variables (Actual scenario above); or, alternatively, we can use the most likely outcome for the year that can be estimated given that we already have third quarter GDP data for most countries

\footnotetext{
${ }^{8}$ Another reason to expect efficiency gains from the SUR methodology arises because El Nino did not affect all countries. Hence the set of explanatory variables in the countries not affected by it is a subset of the explanatory variables included for Peru and Ecuador.

${ }^{9}$ Initially, the specification did not include the current account in industrial countries. Adding this variable improved the explicatory power of the model and was used as the final specification.. US growth rate was dropped out since it turned out to be not significant. This result coincides with Ahmed (1999). However, it might be the consequence of estimating a panel without allowing for slope heterogeneity. A next revision of this estimation should allow for this flexibility to verify this result.
} 
(this is closer to a 1-step forecast). Both approaches lead to different figures: the total slowdown between 1997 and 1999 ranged from 5.7\% to $8.9 \%$ (Table 2). However the conclusion is similar: a large part of the slowdown was due to the external conditions. Given that external factors accounted for 4.6 percentage points, $52 \%$ of the total slowdown is explained by adverse external conditions; this ratio increases to $80 \%$ when calculated with respect to the actual slowdown ${ }^{10}$.

The fact that the slowdown in regional output growth in 1998 and 1999 was driven to a large extent by changes in the international environment should not lead to overlook the role of internal factors in the economic performance of these countries. The empirical evidence presented here does not take into account political or economic domestic developments. The following sections partly overcome this shortcoming by incorporating domestic endogenous variables, such as real interest rates and real exchange rates, in addition to the exogenous factors considered in this section.

Table 2

Latin An erica : External Factors and GDP Growth

\begin{tabular}{|c|c|c|c|}
\hline & \multicolumn{2}{|c|}{$\begin{array}{c}\text { Slowdown }{ }^{1} 1999-1997 \\
\%\end{array}$} & $\begin{array}{c}\text { Effect of External } \\
\text { Shocks on } 1998-99 \\
\text { Growth }{ }^{3} \\
(\%)\end{array}$ \\
\hline Argentina & -12.1 & -10.8 & -4.7 \\
\hline Brazil & -2.8 & -7.6 & -4.8 \\
\hline Chile & -8.6 & -7.4 & -5.1 \\
\hline Colombia & -7.5 & -7.4 & -4.9 \\
\hline Ecuador & -10.7 & -8.2 & -5.2 \\
\hline Mexico & -3.2 & -10.3 & -3.9 \\
\hline Peru & -4.2 & -6.7 & -4.9 \\
\hline Venezuela & -13.5 & -12.5 & -4.4 \\
\hline Weighted Average ${ }^{4}$ & -5.7 & -8.9 & -4.6 \\
\hline $\begin{array}{l}\text { Weighted Average } \\
\text { (excluding Brazil, Mexico } \\
\text { and Peru) }\end{array}$ & -10.7 & -9.9 & -4.8 \\
\hline \multicolumn{4}{|c|}{$\begin{array}{l}\text { 'Slowdown calculated as the difference between } 1999 \text { and } 1997 \text { growth rates. } \\
{ }^{2} \mathrm{~N} \text {-step ahead forecast. } \\
\text { external conditions and the } 1999 \mathrm{~N} \text {-Step ahead forecast using } 1997 \text { average } \\
\text { conditions. } \\
{ }^{4} \text { Weighted by } 1997 \mathrm{GDP} \text {. }\end{array}$} \\
\hline
\end{tabular}

${ }^{10}$ The $52 \%$ figure is a lower bound, since a dynamic panel that neglects slope heterogeneity (like we did) leads to underestimation of the regressor coefficients, other than the lagged dependent variable (Pesaran and Smith, (1995), Haque, Pesaran and Sarma, (1999)). If these coefficients are biased downward, then we underestimate the importance of the changes in external conditions which are the regressors whose value we are changing. 


\section{Country-Specific Analysis: The Role of External and Domestic Factors on Output Variability during 1992-1998}

In this section we examine, on an individual basis for the same set of eight countries, the relationship between output, external capital markets, TOT, real interest rates and real exchange rates during the period 1992-1998. The central objective is to determine the sources of output volatility during this period and to describe output's response to historical shocks in the rest of the variables. To do so, we estimated individual VAR models following the methodology proposed by Koop, Pesaran and Potter (1996). The first part of the section briefly describes the evolution of the main variables for each country. The second part summarizes the main points of the Generalized VAR methodology. The third part presents the results.

\section{A. Behavior of the main variables during the 1992-1999 period}

\section{1) External Factors}

The terms of trade during this period showed a downward trend, aggravated by the Asian crisis that compressed commodity demand worldwide. Fig. 5 shows for individual countries the terms of trade during the period.

Fig. $5 a$

\section{Terms of Trade}

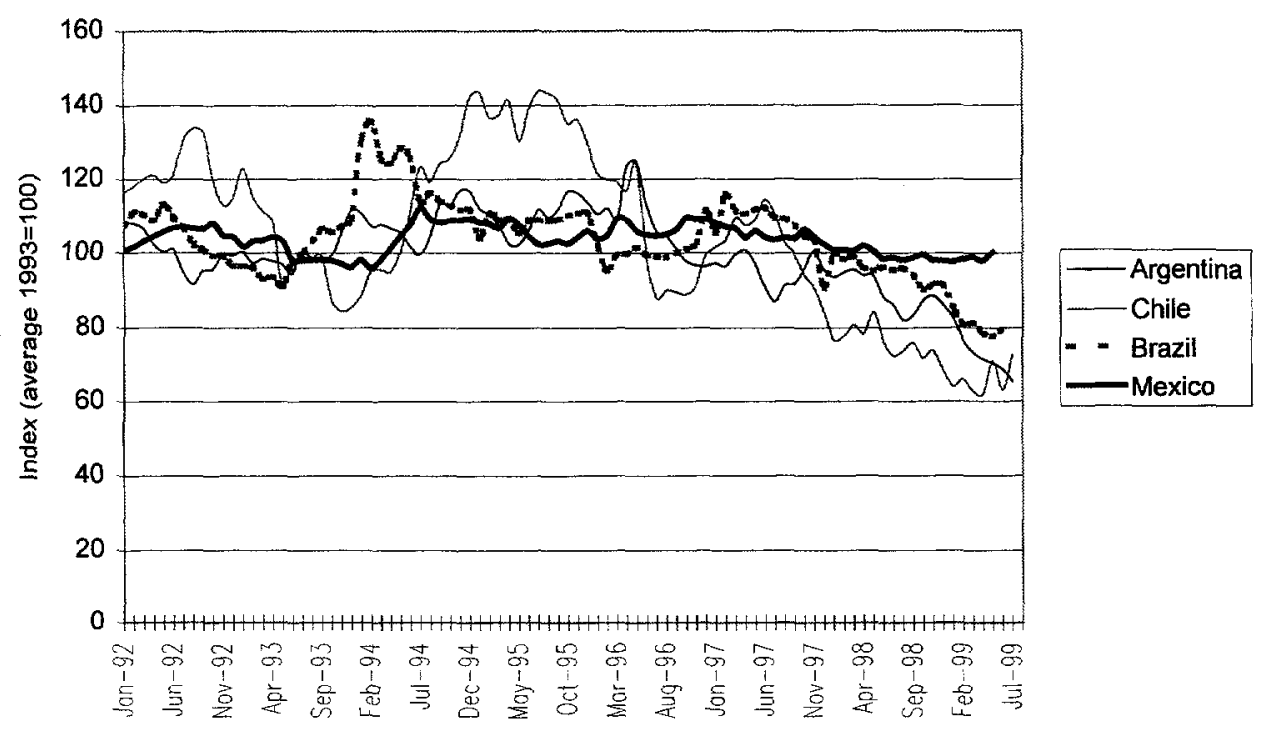

Capital flows to the region were also disrupted. The indicator we used, the sovereign spreads of Brady bonds (Figure 6 ) $^{11}$, shows that recovery after the Tequila shock was

\footnotetext{
${ }^{11}$ The Brady Bond sovereign spreads are available for the whole sample period only for Argentina, Brazil and Mexico. For the other countries we used the Latin American aggregate (LATEMBI), from JP Morgan.
} 
halted first by the Asian crisis of late 1997 and then by the Russian crisis of AugustSeptember of 1998.

Fig. $5 b$

Terms of Trade

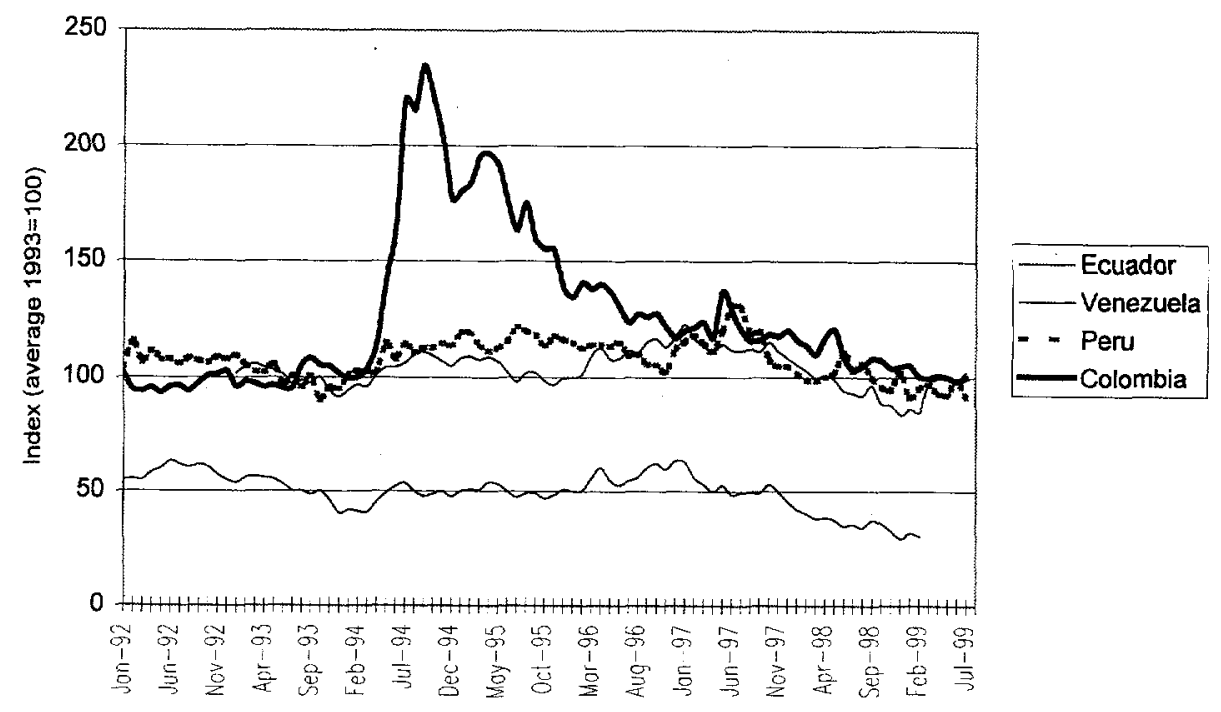

Fig. 6

\section{EMBI Spreads}

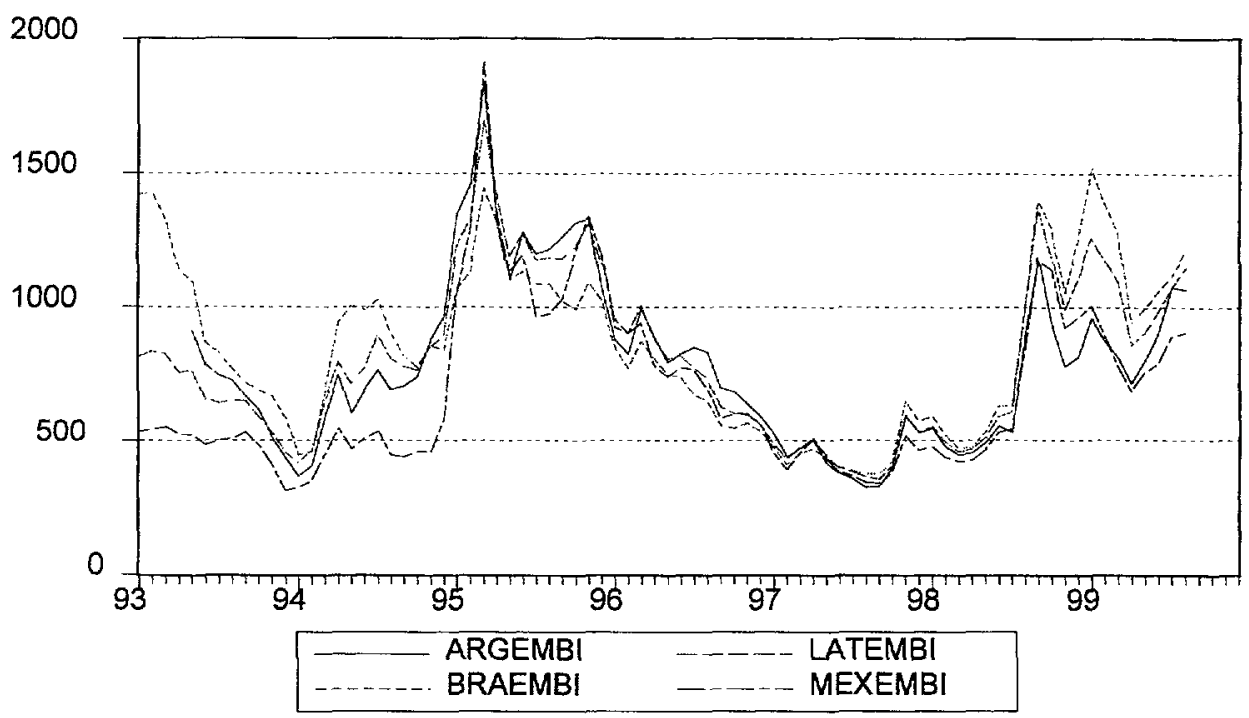

The real exchange rate had diverse behavior across countries ( Figure 7). Argentina's and Mexico's REER had similar trends: first it appreciated until 1994, then it depreciated until 1996, and finally resumed the appreciating trend. In Brazil, Chile and Colombia the trend was an appreciating one until mid or late 1997 when a depreciating trend began. The policy settings were widely different: on one extreme Argentina with its fixed - rate 
convertibility system, and on the other Mexico with a very flexible exchange rate. In the midst we had a combination of rigid bands such as the Brazilian and Chilean, while the Colombian system was one of "adjustable bands" modified on several occasions, downward until 1996 and then upward. All the countries experienced less volatility in the real exchange rate during 1997-1998 (Appendix 3).

Fig. $7 \mathrm{a}$

\section{Real Effective Exchange Rate}

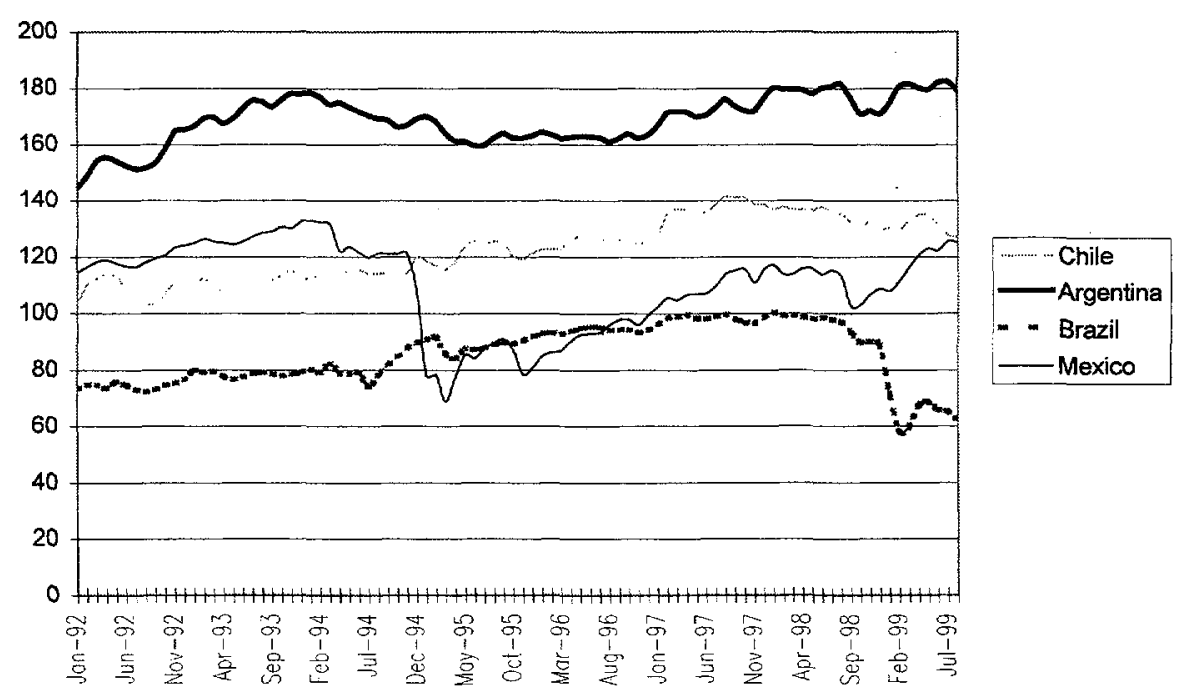

Fig. $7 \mathrm{~b}$

Real Effective Exchange Rate

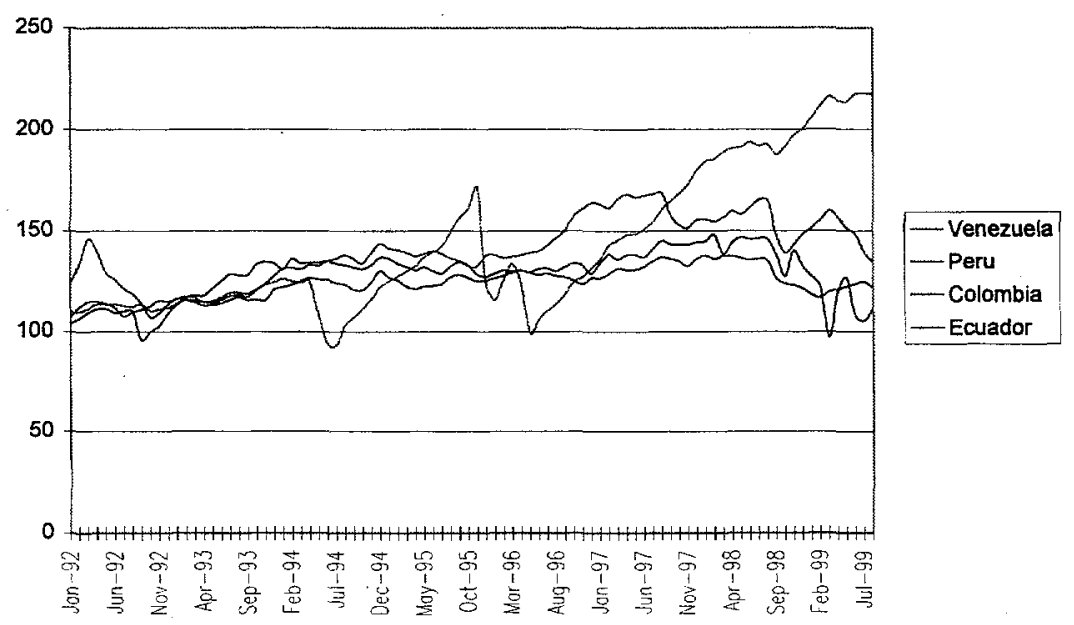

The behavior of real interest rates during the whole period is diverse (Figure 8). In Brazil and Argentina this variable is very volatile at the beginning and then stabilizes. In Colombia and Chile an opposite pattern is observed: volatility follows a period of 
stability. However, all the countries show a rise of interest rates in the 1997-1998 period, even though volatility fell in most of them, except Colombia (Appendix 3).

Fig 8

Real Interest Rates 1992-1999
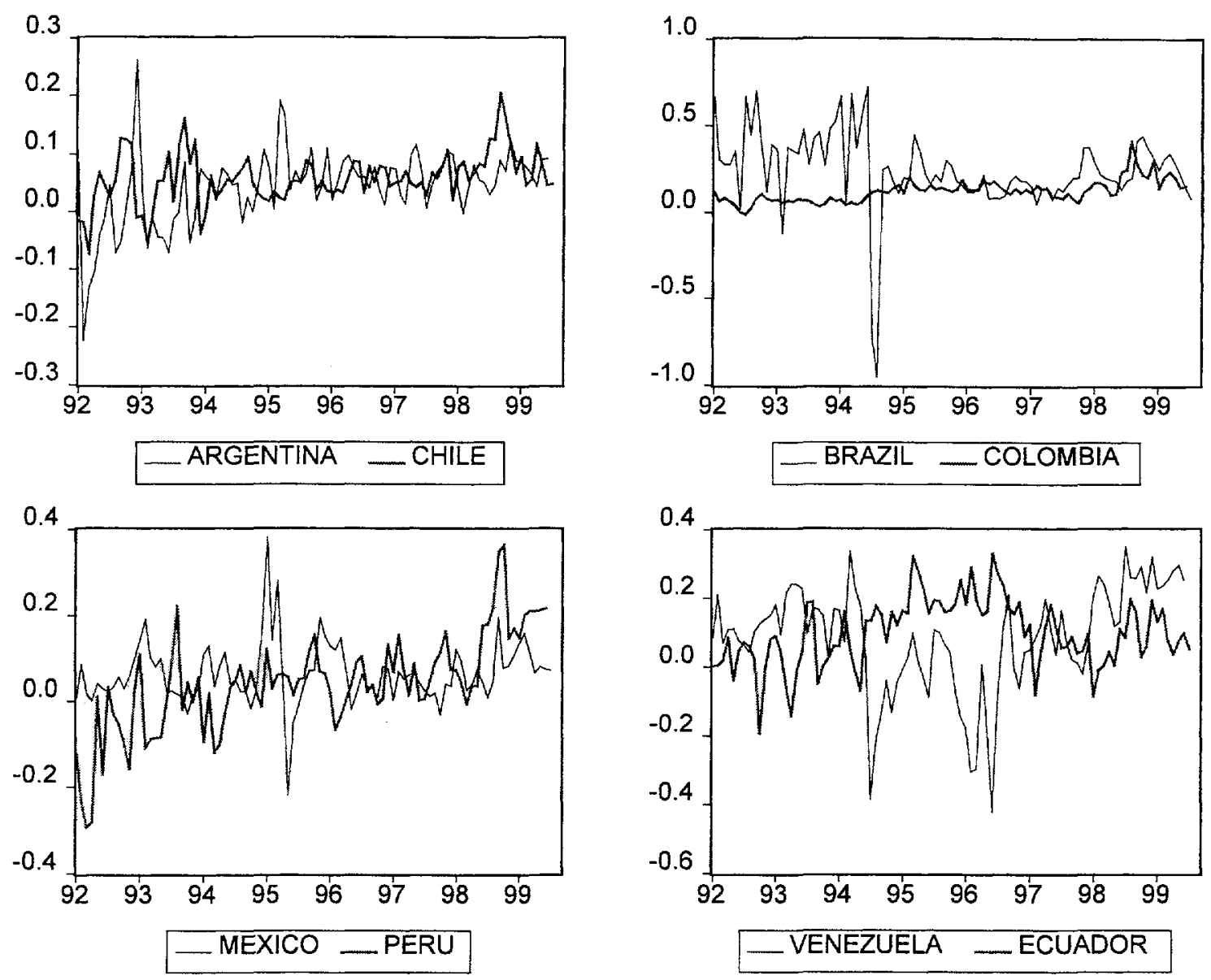

\section{B. Methodology ${ }^{12}$}

Given the potential endogeneity of all the variables and the lags with which they interact, we estimated a VAR model for each country. We use the Generalized VAR (GVAR) methodology (Koop, Pesaran, and Potter (KPP)(1996)) recently applied to study the impact of financial contagion on output in Argentina (Agenor, Aizenman and Hoffmaister, 1999). Appendix 2 briefly describes the methodology, highlighting the main differences with traditional VAR analysis.

\footnotetext{
12 This section follows closely the work by Koop, Pesaran and Potter (1996) and Pesaran and Shin (1998). The reader familiarized with this literature can skip the section without any loss of continuity.
} 
KPP reconsider VAR analysis around two facts: a) shocks to different variable are not independent b) shocks are correlated across time ${ }^{13}$. These two issues led them to examine system-wide shocks (as opposed to variable-specific) and to deal in some manner with future shocks given their autocorrelation. The way they did this was by means of the expectations operator conditional on history and/or shock. The constructed response averages out future shocks, hence it is an average of what might happen in the future given the past and present.

The key features of the Generalized Impulse Response analysis are: a) Impulse response functions and variance decompositions are independent of the ordering of the variables (compositional problem) or any other a-priori restrictions on the variance-covariance matrix of the reduced form residuals $b$ ). The analysis describes how the system behaves after a specific historical shock, taking into consideration the correlation among shocks. Since historical shocks are not orthogonal, they do not add up to $100 \%$.

\section{Results for 1992-1998: Generalized Variance Decomposition of Output and Impulse-Response Functions}

The country-specific GVAR models were estimated using monthly data for the same set of five variables (industrial output growth, real interest rates, real exchange rates, sovereign spreads and terms of trade ${ }^{14}$ ) during the period 1992-1998. To capture international capital markets dynamics we used the Brady Bonds sovereign spread and if the country did not have one the regional average was used. Appendix 3 contains a detailed description and source of each variable).

The lag-selection process was done with different information criteria. The Akaike criterion yielded almost always twelve lags, while the Schwarz criterion pointed at lag one. The likelihood ratio test between the two orders indicated that the longer lag length was preferable ${ }^{15}$. (Appendix 3 presents a summary of the VAR estimates for each country and the coefficient of variation of each of the variables during the sample period.

The generalized variance decomposition of output in the eight countries shows (Table 3) that these variables explain fairly well the forecast error variance of output during this

\footnotetext{
${ }^{13}$ They consider a third issue which is the state of the system prior to the shock and afterwards, but we do not examine this complication here since it applies only to non-linear systems.

${ }^{14}$ Many variables are excluded mainly because of sample size limitations. One of the most obvious exclusions is US output growth, that in the first section turned out to be statistically insignificant. In Mexico's case there is a very close relationship between industrial production in both countries. However, when you include US industrial output in Mexico's VAR very undesirable results emerge: after shocking the TOT, output diverges from stationary levels: the same thing happens when the spreads are shocked. More work is needed in this topic. Another omitted variable is the quantity variable, or the capital flows, but the last section of the paper discusses this issue in more detail.

${ }^{15}$ The only exception was Argentina where 8 lags were used because of data limitations. The variables were differenced to achieve stationarity, hence our analysis does not incorporate potential restrictions imposed by long-run relationships among the non-stationary variables. Again, the main obstacle was the sample size to perform the type of cointegrated VAR analysis done by Ahmed (1999).
} 
sample period". In most countries, the "own" shocks to output explain between $8 \%$ and $40 \%$ of output's error variance, implying that $60 \%$ or more of output variability is explained by shocks to the terms of trade, to external spreads, to the real interest rate and to the real exchange rate. Only in Venezuela and Peru is a substantial percentage (between $55 \%$ and $60 \%$ ) of output variability left unexplained by these factors. These countries are the most volatile in the Hausman-Gavin (1995) paper on volatility in Latin America, where the authors find that in these two countries a good part of GDP volatility is explained by policy variability, financial deepening and political volatility ${ }^{17}$.

Output's "own shocks" capture effects from unidentified variables outside the model. They are, partly, the result of the a-priori marginalization process in which the researcher chooses the specific set of variables whose interaction will be studied. These, however, might be external or internal. These results (Table 3)show that the variance explained by external variables is less than the variance accounted for by the internal factors, except in Argentina If the own shocks to output are classified as reflecting mainly the effect of omitted internal factors, the relative importance shifts even more towards the domestic

\begin{tabular}{|c|c|c|c|c|c|}
\hline & heralized V & Decomp & $\begin{array}{l}\text { ole } 3 \\
\text { n of Industr }\end{array}$ & utput- Arg & \\
\hline \multicolumn{6}{|c|}{ Percentage of the Variance Associated with Shock to: } \\
\hline $\begin{array}{l}\text { Horizon } \\
\text { (in } \\
\text { months) }\end{array}$ & $\begin{array}{c}\text { Terms of } \\
\text { Trade }\end{array}$ & Spreads & $\begin{array}{c}\text { Domestic } \\
\text { Real Interest } \\
\text { Rate }\end{array}$ & $\begin{array}{c}\text { Real } \\
\text { Exchange } \\
\text { Rate }\end{array}$ & Output \\
\hline 1 & 5 & 10 & 4 & 11 & 90 \\
\hline 4 & 11 & 37 & 18 & 13 & 69 \\
\hline 8 & 15 & 54 & 27 & 15 & 49 \\
\hline 12 & 15 & 59 & 21 & 18 & 46 \\
\hline 16 & 14 & 53 & 22 & 22 & 41 \\
\hline 20 & 14 & 51 & 26 & 22 & 39 \\
\hline 24 & 14 & 54 & 27 & 21 & 38 \\
\hline \multicolumn{6}{|c|}{ Generalized Variance Decomposition of Industrial Output- Brazil } \\
\hline \multicolumn{6}{|c|}{ Percentage of the Variance Associated with Shock to: } \\
\hline $\begin{array}{l}\text { Horizon } \\
\text { (in } \\
\text { months) }\end{array}$ & $\begin{array}{c}\text { Terms of } \\
\text { Trade }\end{array}$ & Spreads & $\begin{array}{c}\text { Domestic } \\
\text { Real Interest } \\
\text { Rate }\end{array}$ & $\begin{array}{c}\text { Real } \\
\text { Exchange } \\
\text { Rate }\end{array}$ & Output \\
\hline 1 & 4 & 6 & 12 & 3 & 77 \\
\hline 4 & 4 & 32 & 10 & 59 & 30 \\
\hline 8 & 4 & 31 & 14 & 77 & 11 \\
\hline 12 & 4 & 41 & 10 & 74 & 9 \\
\hline 16 & 4 & 47 & 10 & 68 & 8 \\
\hline 20 & 5 & 48 & 11 & 62 & 8 \\
\hline$\overline{24}$ & 5 & 48 & 12 & 61 & 8 \\
\hline
\end{tabular}

\footnotetext{
${ }^{16}$ We will use the terms forecast error variance of output and output variability interchangeably. The same with the other variables of the model. In Appendix 3 you can see the main statistics of the VAR estimates of each equation. You can see that the $\mathrm{R}^{2}$ for the output equations are quite good for most countries.

${ }^{17}$ See Table 14 of the second part Annual Report, 1995, IADB.
} 
Table 3-Continued

Generalized Variance Decomposition of Industrial Output- Mexico

\begin{tabular}{|c|c|c|c|c|c|}
\hline \multirow{2}{*}{$\begin{array}{l}\text { Horizon } \\
\text { (in } \\
\text { months) }\end{array}$} & \multicolumn{5}{|c|}{ Percentage of the Variance Associated with Shock to: } \\
\hline & $\begin{array}{l}\text { Terms of } \\
\text { Trade }\end{array}$ & Spreads & $\begin{array}{l}\text { Domestic Real } \\
\text { Interest Rate }\end{array}$ & $\begin{array}{l}\text { Real } \\
\text { Exchange } \\
\text { Rate }\end{array}$ & Output \\
\hline 1 & 5 & 1 & 2 & 4 & 96 \\
\hline 4 & 6 & 12 & 5 & 12 & 73 \\
\hline 8 & 5 & 39 & 22 & $4 \overline{3}$ & 36 \\
\hline 12 & 4 & 57 & 37 & 59 & 24 \\
\hline 16 & 3 & 56 & $\overline{41}$ & 61 & 25 \\
\hline 20 & 4 & 50 & 39 & 56 & 26 \\
\hline 24 & 4 & 49 & 37 & 54 & 25 \\
\hline
\end{tabular}

Generalized Variance Decomposition of Industrial Output- Chile

\begin{tabular}{|c|c|c|c|c|c|}
\hline \multirow{2}{*}{$\begin{array}{l}\text { Horizon } \\
\text { (in } \\
\text { months) }\end{array}$} & \multicolumn{5}{|c|}{ Percentage of the Variance Associated with Shock to: } \\
\hline & $\begin{array}{l}\text { Terms of } \\
\text { Trade }\end{array}$ & Spreads & $\begin{array}{l}\text { Domestic Real } \\
\text { Interest Rate }\end{array}$ & $\begin{array}{c}\text { Real } \\
\text { Exchange } \\
\text { Rate }\end{array}$ & Output \\
\hline 1 & 3 & 3 & 13 & 0 & 90 \\
\hline 4 & 4 & 13 & 25 & 8 & 62 \\
\hline 8 & 3 & $\overline{23}$ & 25 & 18 & 47 \\
\hline 12 & 6 & 24 & 27 & 16 & 43 \\
\hline 16 & 7 & 25 & 28 & 16 & 40 \\
\hline 20 & 7 & 25 & 28 & 16 & 39 \\
\hline 24 & 7 & 25 & 29 & 16 & 39 \\
\hline \multicolumn{6}{|c|}{$\begin{array}{l}\text { Table } 3 \text { (Continued) } \\
\text { Decomposition of Industrial Output- Colombia }\end{array}$} \\
\hline \multirow[b]{2}{*}{$\begin{array}{l}\text { Horizon } \\
\text { (in } \\
\text { months) }\end{array}$} & \multicolumn{5}{|c|}{ Percentage of the Variance Associated with Shock to: } \\
\hline & $\begin{array}{l}\text { Terms of } \\
\text { Trade }\end{array}$ & Spreads & $\begin{array}{c}\text { Domestic } \\
\text { Real Interest } \\
\text { Rate }\end{array}$ & $\begin{array}{c}\text { Real } \\
\text { Exchange } \\
\text { Rate }\end{array}$ & Output \\
\hline 1 & 12 & 2 & 23 & 18 & $\overline{79}$ \\
\hline 4 & 16 & 2 & 28 & 22 & 59 \\
\hline 8 & 22 & 9 & 35 & 26 & 49 \\
\hline 12 & 19 & 12 & 47 & 26 & 38 \\
\hline 16 & 18 & 18 & 48 & 28 & 30 \\
\hline 20 & 18 & 21 & 43 & 30 & 27 \\
\hline 24 & 17 & 23 & 41 & 30 & 26 \\
\hline \multicolumn{6}{|c|}{ Generalized Variance Decomposition of Industrial Output- Peru } \\
\hline \multirow[b]{2}{*}{$\begin{array}{l}\text { Horizon } \\
\text { (in } \\
\text { months) }\end{array}$} & \multicolumn{5}{|c|}{ Percentage of the Variance Associated with Shock to: } \\
\hline & $\begin{array}{l}\text { Terms of } \\
\text { Trade }\end{array}$ & Spreads & $\begin{array}{c}\text { Domestic } \\
\text { Real Interest } \\
\text { Rate }\end{array}$ & $\begin{array}{c}\text { Real } \\
\text { Exchange } \\
\text { Rate }\end{array}$ & Output \\
\hline 1 & 14 & 3 & 1 & 6 & 95 \\
\hline 4 & 17 & 4 & 12 & 6 & 81 \\
\hline 8 & 17 & 6 & 13 & 6 & 77 \\
\hline 12 & 28 & 13 & 11 & 13 & 60 \\
\hline 16 & 27 & 12 & 12 & 13 & 59 \\
\hline 20 & 30 & 13 & 11 & 13 & 55 \\
\hline 24 & 30 & 12 & 10 & 11 & 56 \\
\hline
\end{tabular}




\begin{tabular}{|c|c|c|c|c|c|}
\hline \multicolumn{6}{|c|}{ Generalized Variance Decomposition of Industrial Output- Venezuela } \\
\hline & \multicolumn{5}{|c|}{ Percentage of the Variance Associated with Shock to: } \\
\hline $\begin{array}{l}\text { Horizon } \\
\text { (in } \\
\text { months) }\end{array}$ & $\begin{array}{l}\text { Terms of } \\
\text { Trade }\end{array}$ & Spreads & $\begin{array}{l}\text { Domestic } \\
\text { Real Interest } \\
\text { Rate }\end{array}$ & $\begin{array}{l}\text { Real } \\
\text { Exchange } \\
\text { Rate }\end{array}$ & Output \\
\hline 1 & 10 & 7 & 2 & 7 & 88 \\
\hline 4 & 19 & 5 & 19 & 11 & 65 \\
\hline 8 & 29 & 8 & 20 & 20 & 50 \\
\hline 12 & 27 & 14 & 16 & 17 & 54 \\
\hline 16 & 21 & 14 & 13 & 13 & 62 \\
\hline 20 & 18 & 13 & 15 & 11 & 62 \\
\hline 24 & 17 & 13 & 16 & 11 & 60 \\
\hline \multicolumn{6}{|c|}{ Generalized Variance Decomposition of Industrial Output- Ecuador } \\
\hline & \multicolumn{5}{|c|}{ Percentage of the Variance Associated with Shock to: } \\
\hline $\begin{array}{l}\text { Horizon } \\
\text { (in } \\
\text { months) }\end{array}$ & $\begin{array}{l}\text { Terms of } \\
\text { Trade }\end{array}$ & Spreads & $\begin{array}{l}\text { Domestic } \\
\text { Real Interest } \\
\text { Rate }\end{array}$ & $\begin{array}{l}\text { Real } \\
\text { Exchange } \\
\text { Rate }\end{array}$ & Output \\
\hline 1 & 11 & 3 & 9 & 3 & 99 \\
\hline 4 & 35 & 3 & 7 & 6 & 82 \\
\hline 8 & 36 & 13 & 6 & 12 & 62 \\
\hline 12 & 30 & 17 & 17 & 15 & 55 \\
\hline 16 & 34 & 17 & 17 & 13 & 44 \\
\hline 20 & 28 & 14 & 14 & 13 & 35 \\
\hline 24 & 24 & 14 & 26 & 17 & 34 \\
\hline
\end{tabular}

factors as being the main sources of output variability ${ }^{18}$. This last classification does not seem unreasonable, given that we omitted nominal variables and fiscal policy variables which might have been important determinants of short run output fluctuations ${ }^{19}$ These results are in line with those reported by Hausman-Gavin (1995), Hoffmaister- Roldos (1997), and Ahmed (1999) according to which domestic factors were the main sources of output variability in Latin America, even though our sample period and data sets are different.

As expected, growth rates react differently to similar shocks across countries. For example, shocks to the external capital markets play a major role explaining the variance of output growth in Brazil, Mexico and Argentina, while in Venezuela they are the least important factor with an almost negligible effect: in Brazil, Argentina and Mexico these innovations explain about fifty percent $(50 \%)$ of output variance, while in Venezuela they account for less than $15 \%$. This is a reasonable result given Venezuela's low external financing requirements. Colombia, and Chile are intermediate cases where there are other dominant factors that account for output variance.

\footnotetext{
${ }^{18}$ The approach of associating "own" output shocks with domestic factors, common in the literature, has been criticized by Kamin and Babson (1999).

19 The reason for not having included nominal variables are a combination of a) Results of previous papers, such as the Hausman-Gavin (HG) and Hoffmaister-Roldos (HR) in which nominal shocks are absent (HG) or their effects are on output variability is small (HR). b) Data availability imposed degrees of freedom restrictions, limiting the option of including additional variables.
} 
To quantify the effect of external spreads shocks on output, we estimated the following multipliers ${ }^{20}$ based on the impulse response functions (Appendix 4): In Argentina, a onestandard deviation shock has an immediate impact on growth, producing a slowdown of $3 \%$ on average that lasts about 10 months. This result is similar to that obtained by Agenor, Aizenman and Hoffmaister (1999), though their effect is more persistent (15 months) but of smaller magnitude (about $0.5 \%$ on average). In Brazil, a shock of similar magnitude implies a slowdown of $1.4 \%$, but of greater persistence ( 21 months). In Mexico, a one-standard deviation shock reflects in a growth-slowdown on average of $1.6 \%$ and has an effect that lasts 18 months. In Chile, the same sized shock reduces growth by $1.1 \%$. and its effect disappears after 15 months. In Colombia, a similar shock produces a slowdown of about $0.4 \%$ but persists around 18 months.

Domestic real interest rate shocks are a major source of output variability in Chile and Colombia. In Chile, a one-standard deviation shock to real interest rates is associated with a slowdown of $1.3 \%$ on average that lasts a bit over a year. In Colombia, a similar shock results in lower growth of $1.4 \%$ that lasts about 16 months. In Brazil a one standard deviation shock to the real interest rate is associated with lower growth of $.9 \%{ }^{21}$ during nine months. In Argentina, a one-percentage point shock lowers growth by about $2 \%$ during seven months. In Mexico a similar shock lowers growth by $0.6 \%$ during 17 months.

The real exchange rate shocks are the main explanatory factor of output growth variance in Brazil and Mexico. In Argentina, Chile, and Colombia it's the second or third most important factor accounting for the variance of output. In every case the impulseresponse functions shows (Appendix 4) that real exchange rate-appreciating shocks are associated with output expansions. The negative association between output growth and currency depreciation in the short run (we used a 24-month horizon) is common to previous studies aboui this topic in Latin America (Edwards, 1989; Kamin and Rogers, 1997, Ahmed, 1999) ${ }^{22}$

Terms of trade shocks are the dominant source of output variability in Ecuador, Peru and Venezuela (in the 8-16 months horizon), though, as mentioned before, a major part of the forecast error variance remains unexplained by our model in the last two countries. In

\footnotetext{
${ }^{20}$ These multipliers are the average values of the impulse response functions from the moment of the shock until its persistence lasts. Appendix 4 presents the impulse response functions.

${ }^{21}$ The relatively small number is due to the fact that real interest rates have a huge variability in Brazil. One standard deviation shock is a 24 percentage point shock that reduces growth in $0.9 \%$. In Chile, a one standard deviation shock (3.4 percentage points) reduces growth by $1.3 \%$. This comment applies to all the multipliers we are describing in this section and in Appendix 4 you can see the magnitudes of one standard deviation shocks for each series.

${ }^{22}$ The VAR including the rate of growth of output and the real exchange rate in differences has the problem of not incorporating restrictions imposed by possible long-term relationships between the variables. Ahmed (1999) used a cointegrating VAR methodology for a different sample period and different variables, but the results are similar to those reported here. Unfortunately, our sample size and the lag-lengths we selected do not allow similar estimations, forcing us to interpret our results as applicable to the short run. Kamin-Klau (1998) proposed an alternative methodology for incorporating the long-run relationship, and for a subset of Latin American countries find that the contractionary effect does not hold in the long-run.
} 
Argentina and Colombia the TOT shocks have an effect of intermediate significance, while they appear relatively unimportant in Brazil, Chile and Mexico. From the impulseresponse functions (Appendix 4), the following multipliers can be obtained: In Argentina, a one standard deviation shock in the index will raise growth by $1.3 \%$ during twelve months. In Brazil a similar shock will increase growth by $0.2 \%$ during 18 months. In Chile a one standard deviation shock in the terms of trade variable increases growth $0.3 \%$ during 17 months. In Colombia, a shock of similar size raises growth by $0.4 \%$ during 21 months, while in Mexico it raises growth by $0.2 \%$ during two years.

Table 4 summarizes the sensitivity of output growth to shocks in different variables, as well as the persistence of the shocks in each of the five countries under consideration. This information was calculated on the average behavior of the system for the sample period 1992-1998 and will be used in the next section to examine 1998-1999 in more detail.

\section{The Role of External and Domestic Factors on the 1998/1999 Slowdown}

In this section we aim at accounting for the 1998-1999 slowdown in a sub-set of economies of the region (Argentina, Brazil, Chile, Colombia and Mexico). Based on the generalized impulse response functions estimated for the whole period and the shocks that took place during 1997-1999, we calculate approximately the importance of each variable explaining growth rate changes during 1998 and 1999.

\begin{tabular}{|l|c|c|c|c|}
\hline \multicolumn{5}{|c|}{ Table 4 } \\
\hline \multicolumn{3}{|c|}{ Average change in output growth due to a historical one standard deviation shock in: } \\
\hline & TOT & Spreads & Real Interest rates & $\begin{array}{c}\text { Real Exchange } \\
\text { Rates }\end{array}$ \\
\hline Argentina & 1.3 & 3.0 & 2.0 & 1.5 \\
\hline Brazil & 0.2 & 1.4 & 0.9 & 1.0 \\
\hline Chile & 0.3 & 1.1 & 1.3 & 0.6 \\
\hline Colombia & 0.4 & 0.4 & 1.4 & 0.6 \\
\hline Mexico & 0.2 & 1.6 & 0.6 & 1.2 \\
\hline \multicolumn{2}{|c|}{ Persistence (in number of months) on output growth after a shock to: } \\
\hline & TOT & Spreads & Real Interest rates & Real Exchange \\
\hline Argentina & & & & Rates \\
\hline Brazil & 12 & 10 & 7 & 18 \\
\hline Chile & 18 & 21 & 9 & 12 \\
\hline Colombia & 17 & 15 & 13 & 15 \\
\hline Mexico & 21 & 18 & 17 & 18 \\
\hline
\end{tabular}

Table 5 summarizes the evolution of the original variables during this sub-period. The identification of shocks, their timing and measurement is a difficult task due to the endogeneity of all the variables. To account for all the interaction between the variables we used the VAR to forecast the variables and then compared the forecasted value with the observed one. The discrepancy between the forecasted value and the observed one 
was considered a shock if it exceeded two standard errors of the respective VAR equation (Appendix 2 shows the SE of each equation). Initially the VAR was estimated with data up to 1996 and the whole set of variables was forecasted for the first three months of 1997. Then, the VAR was re-estimated with data up to the first quarter of 1997 to forecast the second three months for 1997. This procedure was repeated recursively for each quarter until June, 1999.

\begin{tabular}{|c|c|c|c|c|c|}
\hline \multicolumn{6}{|c|}{$\begin{array}{c}\text { Table } 5 \\
\text { Yearly Average Values of Different Variables } 1997-1999^{*}\end{array}$} \\
\hline & $\begin{array}{l}\text { Terms of Trade } \\
\text { Index }\end{array}$ & $\begin{array}{c}\text { Spreads } \\
\text { (basis points) }\end{array}$ & $\begin{array}{c}\text { Domestic real } \\
\text { Interest rates } \\
(\%)\end{array}$ & $\begin{array}{l}\text { Real exchange } \\
\text { Rate Index }\end{array}$ & $\begin{array}{c}\text { Industrial } \\
\text { Output Growth } \\
\text { Rate } \\
(\%)\end{array}$ \\
\hline \multirow{3}{*}{ Brazil } & 95 & 451 & 17.9 & 118 & 4.0 \\
\hline & 94 & 822 & 26.3 & 116 & -2.0 \\
\hline & 79 & 1197 & 29.5 & 82 & -3.3 \\
\hline & 95 & 438 & 6.8 & 169 & 14.4 \\
\hline $\begin{array}{r}\text { Argentina } 97 \\
98\end{array}$ & 89 & 677 & 6.0 & 174 & 2.2 \\
\hline \multirow{2}{*}{$\begin{array}{lr} & 99 \\
\text { Mexico } & 97\end{array}$} & 74 & 845 & 7.1 & 177 & -9.9 \\
\hline & 50 & 419 & 3.3 & 109 & 9.3 \\
\hline \multirow{2}{*}{$\begin{array}{rl}\text { Miexico } & 9 \\
98 & 98 \\
99 & 0\end{array}$} & 47 & 696 & 7.6 & 111 & 6.7 \\
\hline & 47 & 841 & 7.1 & 119 & 3.3 \\
\hline \multirow[t]{3}{*}{ Chile } & 14 & 447 & 5.7 & 135 & 4.0 \\
\hline & 10 & 778 & 10.5 & 133 & -1.0 \\
\hline & 9 & 1063 & 4.9 & 129 & -4.2 \\
\hline \multirow{2}{*}{$\begin{array}{r}\text { Colombia } 97 \\
98\end{array}$} & 125 & 447 & 11 & 161 & 2.5 \\
\hline & 113 & 778 & 21.8 & 155 & -1.0 \\
\hline 99 & 104 & 1063 & 16.8 & 148 & -18.0 \\
\hline
\end{tabular}

With the positive and negative shocks identified in this fashion ${ }^{23}$, and the impact multipliers and the persistence information described by the impulse response functions, we estimated the most probable effects of the historical shocks on output growth.

The net effects of the identified shocks with the models (Tables 6 and 7) show that during 1998, in Argentina and Mexico the main contractionary effect came from the external factors. In Brazil the importance was balanced between external and domestic factors, while for Chile and Colombia internal factors were the dominant forces exerting downward pressure. In 1999, the main slowing effect came from the external factors for all countries.

${ }^{23}$ Appendix 5 contains the list of the estimated shocks, and a summary of their description. To simplify matters, we considered the observed changes in the TOT as the magnitude of the shock. This is equivalent as considering the TOT as a completely exogenous variable. If two shocks of the same sign occurred within the same quarter, only one was considered to allow for possible correlation of the shocks. For descriptive purposes, we present the average size of the shocks for each variable in each country during 1997-1999 (Appendix 5). 
Table 6

\begin{tabular}{|lcccc|}
\hline & \multicolumn{4}{c}{ Net Effects of Shocks } \\
1998 \\
& & \multicolumn{3}{c|}{} \\
& Terms of Trade & Spread & Real Interest & REER \\
Argentina & -3.7 & -5.0 & -2.0 & -4.5 \\
Brazil & -0.4 & -3.0 & -2.3 & -1.1 \\
Chile & -1.0 & -0.6 & -3.1 & -1.0 \\
Colombia & -0.5 & -0.8 & -5.2 & -2.1 \\
Mexico & -4.2 & -2.9 & -0.3 & 2.5 \\
\hline
\end{tabular}

Table 7

\begin{tabular}{|lcccc|}
\hline \multicolumn{5}{c|}{ Net Effects of Shocks } \\
\multicolumn{5}{c}{$\mathbf{1 9 9 9}$} \\
Argentina & Terms of Trade & Spread & Reallnterest & REER \\
Brazil & -7.0 & -2.4 & -2.2 & -1.5 \\
Chile & -1.3 & -4.7 & -1.5 & -0.8 \\
Colombia & -1.7 & -3.0 & 1.3 & -2.4 \\
Mexico & -0.8 & -2.7 & 0.1 & -4.9 \\
\hline
\end{tabular}

For the whole period 1998-1999 (Table 8), this methodology predicted big falls in output growth rates in Argentina, Brazil and Colombia. This actually happened in Argentina and Colombia. Similarly, in those countries where the method predicted the smallest falls, these took place. In general the forecast error is not very big as a percentage of the forecasted value, except in Brazil and Mexico. In both cases the observed slowdown was 
significantly smaller than the forecasted one. This result is similar to that reported in the quarterly GDP exercise in the first section (Table 2), where these two countries defy the model's forecasting ability. In Mexico's case, the omission of US output is definitely related to this outcome and points at the need of further working on this issue.

\begin{tabular}{|c|c|c|c|}
\hline \multicolumn{4}{|c|}{$\begin{array}{c}\text { Table } 8 \\
\text { Predictions for 1998-1999 and observed changes in industrial output growth rates }\end{array}$} \\
\hline & $\begin{array}{c}\text { (1) } \\
\text { Predicted total } \\
\text { effect of shocks } \\
1998-1999\end{array}$ & $\begin{array}{l}\text { (2) } \\
\text { Observed changes } \\
\text { in industrial output } \\
\text { growth rates }\end{array}$ & $\begin{array}{c}\text { (3) } \\
\text { Effects of } \\
\text { unidentified shocks }\end{array}$ \\
\hline Argentina & -28.3 & -24.3 & +4.0 \\
\hline Brazil & -15.1 & -7.3 & +8.5 \\
\hline Chile & -9.5 & -8.2 & +1.3 \\
\hline Colombia & -16.9 & -20.5 & -3.6 \\
\hline Mexico & -9.3 & -6.0 & +3.3 \\
\hline
\end{tabular}

To evaluate the relative importance of external factors vis-à-vis the domestic ones, we compute the ratio of the net effects of the external variables to the total predicted effect of the shocks. Due to the differences between the predicted change and the observed value, the ratio of the net external effects to the observed change in output growth was also computed. In all the countries, except Colombia, the ratios are well above .5 (Table 9), pointing at the importance of external factors explaining output fluctuations in the subperiod 1998-1999.

\begin{tabular}{|l|c|c|}
\hline \multicolumn{3}{|c|}{$\begin{array}{c}\text { Table } 9 \\
\text { Effects of external factors on growth as a ratio of the total predicted changes and the } \\
\text { observed changes in output growth }\end{array}$} \\
\hline & $\begin{array}{c}\text { External effects/Total } \\
\text { predicted effects }\end{array}$ & $\begin{array}{l}\text { External effects/ Observed } \\
\text { changes }\end{array}$ \\
\hline Argentina & .64 & .74 \\
\hline Brazil & .62 & 1.29 \\
\hline Chile & .66 & .77 \\
\hline Colombia & .28 & .23 \\
\hline Mexico & 1.3 & 2.1 \\
\hline
\end{tabular}

These results coincide with those obtained from the panel exercise with quarterly GDP (Table 2), according to which about $50 \%$ of the observed regional slowdown in 19981999 was due to external effects. Colombia is the country where the slowdown is less related to the external factors (Table 9). Brazil and Mexico, in contrast, seem to be the more affected by external shocks. These results support the Joyce-Kamas (1997) study of Mexico and Colombia where they conclude that external factors are the main source of 
output volatility in the first country while the opposite holds for the second one. Most importantly, both results point at the difficulty of generalizing on a single dominant source of output volatility.

The crucial result emerging from this section is that a large share of the slowdown was due to external effects, while for the whole period 1992-1998 we had obtained that domestic factors were the main sources of output volatility. This difference can be explained not only because of the severity of the external shocks that took place in the latter part of the decade, but also because the region managed to achieve stability in key variables that were previously noisy factors in the growth process ${ }^{24}$. Some suggestive statistics (Appendix 3) show that real exchange rates and real interest rates were less volatile $^{25}$ in the period 1997-1998, than in the previous five years; external variables, on the other hand, were more volatile during the second sub-sample.

\section{Other issues for further research}

\section{a) On the use of sovereign spreads to capture the effects of international financing shocks}

Between $30 \%$ and $70 \%$ of the variability of external spreads (Appendix 6 ) is explained by own shocks, implying that the other variables account for a non-negligible portion of the variance. In Argentina, shocks to real interest rates and to the terms of trade jointly account for a similar fraction as the own shocks explaining external spread variability. This result differs from that of Agenor, Aizenman and Hoffmaister (1999) where shocks to other variables account for a minimal fraction of the variance of the external spreads. Appendix 6 shows the factors that explain spread variability in each of the countries.

The possibility exists that the spreads don't capture correctly the happenings in international credit markets ${ }^{26}$. This would be the case if credit rationing took place in this market, implying that a quantity variable should be used. To examine this hypothesis, we constructed a monthly proxy of capital flows in each country by taking the sum of the

\footnotetext{
${ }^{24}$ The possibility of a shift in the relative importance between domestic and external factors accounting for currency crisis in Latin countries is hinted by Kamin and Babson (1999) in their conclusion.

${ }^{25}$ Volatility measured by the coefficient of variation (standard deviation/mean). More analysis on these issues is needed, for example, on the measurement of volatility with GARCH models.

${ }^{26}$ The hypothesis that our spreads variable could not be reflecting adequately the international financial markets conditions emerged after we did some ex-post model specification intuitive or suggestive testing consisting in taking the forecast error (difference between the actual value and the forecasted one) for each country and correlating it with variables that had been omitted mainly because of sample size limitations or because the information didn't exist with monthly frequency, but for which we had yearly data. Such is the case of government spending, fiscal deficit, private credit growth as a fraction of GDP, the current account balance and other variables (Appendix 7). The rank correlation exercise shows that there is no systematic relationship between the forecast errors and any of these omitted variables. However, the only systematic relationship emerged between the forecast error and the lagged values of the current account hinting at the possibility that our external financing we had used was inappropriate. This is the subject of the next few paragraphs and Appendix 8.
} 
(negative of) the trade balance and the change in international reserves ${ }^{27}$. In some countries, like Argentina, Brazil and Mexico a strong negative correlation between the spreads and the capital flows proxy was obtained (Fig 9). That is when capital flows in, spreads go down or vice-versa. If this were always the case, then either of the variables could be used and the quantity variable would have no additional information.

Fig. 9

Capital Flows and Spreads in Some Latin American Countries (normalized data)

Argentina

Capital Flows Proxy and Spreads

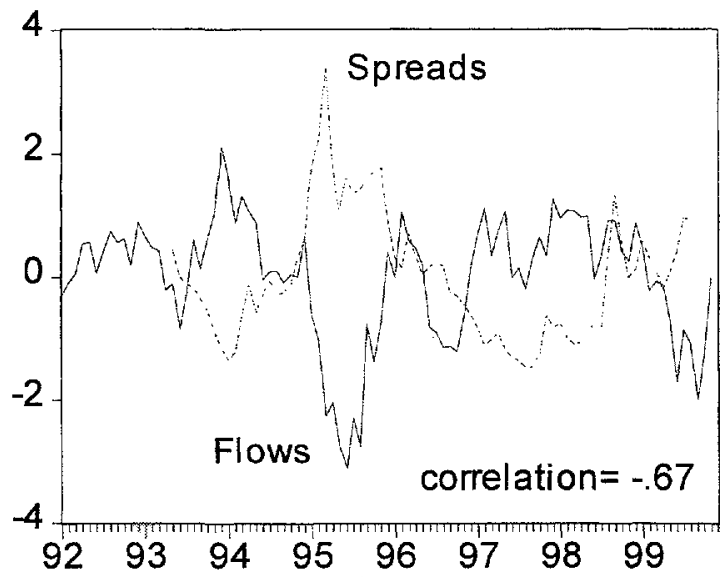

Mexico

Capital flows proxy and sovereign spreads

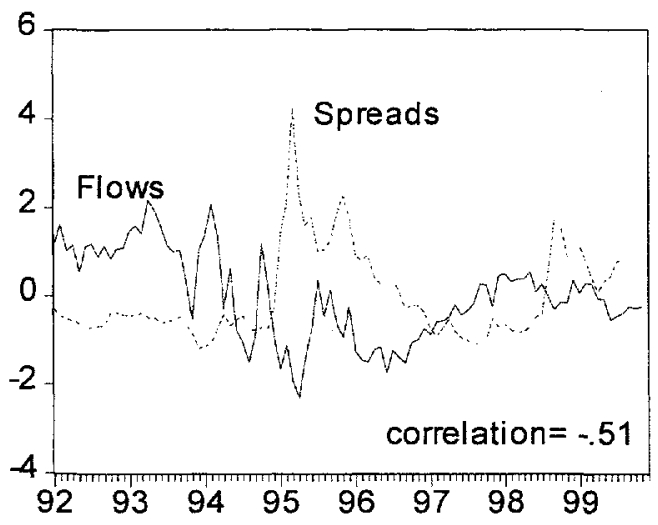

Brazil

Capital Flows Proxy and Spreads

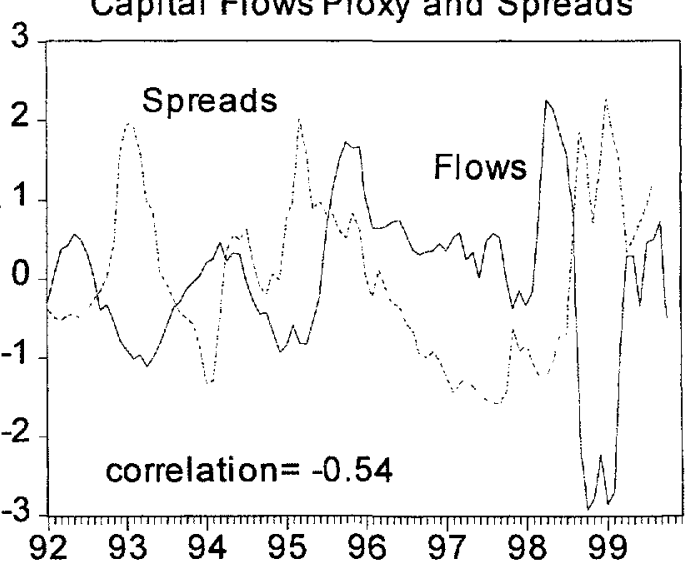

To verify statistically this hypothesis we adopted two alternative approaches: first, we verified the nested hypothesis that a more general model (including both the spreads and capital flows) was not selected over a restricted model (including spreads or capital flows

\footnotetext{
${ }^{27}$ Ideally we should have used the capital account of the balance of payments, or the current account. However no monthly information exists for these variables, so we used the described indicator. The indicator was the smoothed with a six-month moving average for the graphs presented in the text.
} 
only). Second, we used some non-nested tests to select between "competing" models: a spreads only model vs. a flows only one. Appendix 7 presents details of the model selection procedures, but we find no compelling evidence for the more general model, except for the cases of Colombia and Mexico, and probably in Brazil. Future versions of this paper that allow for different specifications should take this into consideration.

\section{b) What Accounts for Real Interest Rate Variability?}

Looking at the real interest rate variance decomposition (Appendix 6), several things are worth noting. First, this set of variables explains reasonably well real interest rate variability in the sample countries. In Argentina, Mexico and Peru, shocks to the external capital markets (external spreads) were the main factor explaining real interest rate variability.

The second most common source of real interest rate variability was the real exchange rate. While in Argentina the importance of this variable quickly fades away, in Mexico, Peru and Brazil its relative weight is stable and of significant magnitude.

In Chile and Colombia the "own" shocks to interest rates are the most important factor explaining interest rate variability. In these two cases, this variable can be considered largely exogenous with respect to the rest of the variables in the model. This finding might be related to the fact that these two countries imposed some type of capital controls during this period.

\section{c) Determinants of Real Exchange Rate Variability}

Variance decomposition of real exchange rates (Appendix 6) shows that in most countries, shocks to the external capital markets are the main explanatory variable (besides the own shocks) of real exchange rate variability. This contrasts with the Roldos-Hoffmaister (1997) result according to which domestic shocks are the main drivers of real exchange rate variability.

\section{Conclusions}

Based on the country-specific Generalized Variance Decompositions we found that during 1992-1998 output variability in most Latin American countries was associated with domestic factors. These results coincide with other work (Hausman-Gavin (1995), Hoffmaister-Roldos (1997) and Ahmed (1999). In four of the eight countries (Brazil, Chile, Colombia, Mexico) the joint effect of shocks to domestic factors (real interest rates and real exchange rates) on output variability was greater than the combined effect of shocks to external variables (terms of trade and external spreads). In Argentina, Brazil and Mexico, shocks to external spreads played a major role, while in Chile and Colombia real interest rates shocks were the principal sources of output variability. In the remaining three countries, Ecuador, Peru and Venezuela, terms of trade shocks were 
dominant sources of output variability, but a significant proportion of output variability is explained by output's own shocks, or remains to be explained.

However, explaining the 1998-1999 slowdown a different picture emerged: In the panel exercise we found that, for the region as a whole, at least $50 \%$ of the slowdown was attributable to the adverse external conditions. In the country-specific analysis we found that in Argentina, Brazil, Chile and Mexico shocks to the terms of trade and external spreads account for at least $60 \%$ of the slowdown, while in Colombia internal factors played the major role.

The results according to which domestic factors explain the largest share of output variability during the whole sample period, but external factors account for the largest share of the 1998-1999 slowdown can be reconciled given the severity of the external shocks registered in the last part of the decade and that the countries managed to reduce real exchange rate and real interest rate volatility during the last two years of our sample. The fact that external factors account for such a large share of the regional slowdown cannot be interpreted as a denial of the role that economic policy might play. Precisely the opposite. The shift in relative importance between external and domestic factors explaining output fluctuations can be thought of as an achievement of economic management in most of the countries in the latter part of the decade. More research is needed on the determinants of real interest rates and exchange rates in the region.

These results might be useful in the debate over the appropriate exchange rate regime, if we stretch them to associate external shocks (terms of trade and external spreads) with real shocks. Then a very basic model in which agents have no big liabilities denominated in foreign currency would indicate that in the face of adverse external shocks a relative price adjustment will reduce output volatility. Considering this benchmark case, then Brazil and Mexico, where external shocks explained the biggest part of the slowdown, made the right choice of adopting a more flexible exchange rate in terms of output stabilization. Coincidentally, these two countries were the ones in which both of our models predicted bigger slowdowns than those actually observed.

The importance of terms of trade shocks accounting for output volatility during the whole period 1992-1998 in a group of countries (Colombia, Venezuela, Ecuador and Peru) and the major role these shocks played in the 1998-1999 slowdown in some others (Argentina and Chile) points at the need of making important gains in the area of stabilization mechanisms. Hausman-Gavin (1995) pointed at some problems with existing schemes in the region. A matter that deserves some attention is related with the funding of such schemes if the falls in commodity prices are of permanent nature or long persistence (Cashin, Liang and Mc Dermott, 1999). Alternative risk-hedging instruments must be devised, such as commodity-price indexed debt instrument would have the desirable property of the country paying less in bad times and more in good times. Probably they are not widely used by the countries of the region because they might be more costly, but episodes as those of 1998-1999 show they might be insurance worth its price.

Appendix 1- Panel Estimation Results 
Appendix 2-Description of the GVAR methodology

Appendix 3- Description of the variables, summary of VAR estimates for each country, and coefficient of variation of variables included in each VAR.

Appendix 4- Generalized Impulse Response functions for output.

Appendix 5-Shocks, identification: dates and magnitude

Appendix 6- Generalized Variance Decomposition for the other variables besides output Appendix 7-Rank correlation exercise

Appendix 8- Model Selection Summary

\section{References}

Agenor, P.R. , J. Aizenman and A. Hoffmaister (1999) "Contagion, bank lending spreads, and output fluctuations". Mimeo. June.

Ahmed, Shaghil (1999) Sources of economic fluctuations in Latin America and implications for choice of exchange rate regimes. Mimeo. Federal Reserve Board. December.

Blanchard, O. and D. Quah "The dynamic effects of aggregate demand and supply disturbances", American Economic Review, 79, pp.655-673.

Calvo, G..,L. Leiderman and C. Reinhart (1993) "Capital inflows and real exchange rate appreciation in Latin America: The role of external factors", IMF Staff Papers, 40, 1, pp $108-151$

Canova, Fabio (1995) "The economics of VAR models", Macroeconometrics: developments, Tensions and Prospects, ed. K. Hoover. Kluwe Academic Publishers.

Cashin, P., Lian, H. and C.J. Mc Dermott (1999) "How persistent are shocks to world commodity prices?", IMF Working Papers.WP/99/80.

Gourieroux, C. and A. Monfort (1997) Time Series and Dynamic Models Cambridge University Press

Haque,N., H. Pesaran, S. Sharma (1999) "Neglected heterogeneity and dynamics in cross-country savings regressions". Mimeo. Trinity College. January

Hausman, R. and M. Gavin (1995) Hacia una Economia Menos Volatil BID, Informe Annual.

Hoffmaister, A. and J. Roldos (1997) "Are business cycles different in Asia and Latin America?" IMF Working Paper., January. 
Joyce, J. and L. Kamas (1997) "The relative importance of foreign and domestic shocks to output and prices in Mexico and Colombia", Weltwirtschaftliches Archiv, Vol. 133, 3.

Kamin, S. and O. Babson (1999) "The contributions of domestic and external factors to Latin American devaluation crisis: An early warning system approach" International Finance Discussion Paper, 645, September. FRBG.

Kamin, S. and M. Klau (1998) "Some multi-country evidence on the effects of real exchange rates on output." International Finance Discussion Paper, 611. FRBG.

Koop, G., H. Pesaran and S. Potter (1996) "Impulse response in non-linear multivariate models", Journal of Econometrics, 74, pp.119-147

Pesaran, H. and B. Pesaran (1997) Working with Microfit 4.0 Camfit Data ltd.

Pesaran, H. and Y. Shin (1998) "Generalized impulse response analysis in linear multivariate models", Economics Letters, pp.17-29

Pesaran H. and R. Smith (1995) "Estimating long-run relationships from dynamic heterogeneous panels", Journal of Econometrics, vol 68 pp. 79-113

Pesaran, H. and M. Weeks (1999) Non-nested hypothesis testing: An overview. University of Cambridge. Mimeo. September. 


\section{Appendix 1- Panel Estimation Results}

A) External Factors and GDP Growth.- Panel Estimation Results.

Table 1: Exogenous Factors and GDP Growth 1992-1997

Panel Regression

Sample: 1992:01 1997:4

\begin{tabular}{|c|c|c|c|c|}
\hline Variable & $\mathrm{Co}$ & efficient & $\mathrm{t}$-Statistic & \\
\hline$\Delta_{4} Y_{-1}$ & & 0.632 & $14.041\left(^{*}\right)$ & \\
\hline$\Delta_{4} Y_{-4}$ & & -0.452 & $-9.703\left(^{*}\right)$ & \\
\hline$\Delta_{4} Y_{-5}$ & & 0.261 & $5.584(*)$ & \\
\hline$\Delta_{4} T O T$ & & 0.040 & $8.323\left(^{*}\right)$ & \\
\hline$\Delta_{4} T_{O} T_{-4}$ & & 0.042 & $6.592\left(^{*}\right)$ & \\
\hline$U S I_{-2}$ & & -0.006 & $-5.647\left(^{*}\right)$ & \\
\hline$C A I_{-2}$ & & 0.0003 & $1.963(* *)$ & \\
\hline$\triangle_{4} S P D_{-3}$ & & -0.010 & $-3.477(*)$ & \\
\hline$I S O_{-4}$ & & 0.001 & $3.848\left(^{*}\right)$ & \\
\hline \multicolumn{5}{|l|}{ Fixed Effects } \\
\hline Argentina & & 0.035 & & \\
\hline Brazil & & 0.026 & & \\
\hline Chile & & 0.055 & & \\
\hline Colombia & & 0.027 & & \\
\hline Ecuador & & 0.026 & & \\
\hline Mexico & & 0.026 & & \\
\hline Peru & & 0.052 & & \\
\hline Venezuela & & 0.022 & & \\
\hline & 0.744 & \multicolumn{2}{|c|}{ Mean dependent var } & 0.044 \\
\hline $\mathrm{R}^{2}$ adjusted & 0.713 & \multicolumn{2}{|c|}{ S.D. dependent var } & 0.042 \\
\hline S.E. of regression & 0.023 & \multirow{2}{*}{\multicolumn{2}{|c|}{ Sum squared resid }} & 0.068 \\
\hline Durbin-Watson & 1.69 & & & \\
\hline
\end{tabular}

(*) Significant at 1\%.(**) Significant at $10 \%$.

\section{B) Methodology}

To quantify the effect of the external factors on the decline in output growth observed in 1998 and 1999 , we followed a two step procedure:

First Step: Estimate (1) for the period 1992-1997. Results of the estimation are in Table 1.

Second Step: With the resulting coefficients we forecast 1998 and 1999 growth rates under two scenarios: a) actual values for external conditions are used in the forecast; b) 'constant external environment'. That is, forecast 1998 and 1999 assuming that terms of trade, interest rates, non-Latin spreads, current account in industrial countries, and El Niño factor take the average value observed in 1997. We use N-Step ahead forecasts. 
Table 2: External Factors and GDP Growth 1992-1999

Sample: 1992:1 1999:3

\begin{tabular}{|c|c|c|c|}
\hline Variable & Coefficient & $\mathrm{t}$-Statistic & \\
\hline$\overline{\Delta_{4} Y_{-1}}$ & 0.741 & $18.955\left(^{*}\right)$ & \\
\hline$\Delta_{4} Y_{-4}$ & -0.446 & $-8.530\left(^{*}\right)$ & \\
\hline$\Delta_{4} Y_{-5}$ & 0.263 & $5.428(*)$ & \\
\hline$\triangle_{4} T O T$ & 0.038 & $6.155\left(^{*}\right)$ & \\
\hline$\Delta_{4} T O T_{-4}$ & 0.040 & $5.235\left(^{*}\right)$ & \\
\hline$U S I_{-1}$ & -0.005 & $-6.259\left(^{*}\right)$ & \\
\hline$C A I_{-2}$ & 0.0004 & $2.984(*)$ & \\
\hline$\triangle_{4} S P D_{-3}$ & -0.010 & $-5.491\left(^{*}\right)$ & \\
\hline$I S O_{-4}$ & 0.0004 & $4.222\left(^{*}\right)$ & \\
\hline \multicolumn{4}{|l|}{ Fixed Effects } \\
\hline Argentina & 0.029 & & \\
\hline Brazil & 0.024 & & \\
\hline Chile & 0.042 & & \\
\hline Colombia & 0.021 & & \\
\hline Ecuador & 0.021 & & \\
\hline Mexico & 0.029 & & \\
\hline Peru & 0.040 & & \\
\hline Venezuela & 0.020 & & \\
\hline $\mathbf{R}^{2}$ & \multicolumn{2}{|c|}{ Mean dependent var } & 0.032 \\
\hline $\mathrm{R}^{2}$ adjusted & \multicolumn{2}{|c|}{ S.D. dependent var } & 0.047 \\
\hline S.E. of regression & \multirow{2}{*}{\multicolumn{2}{|c|}{ Sum squared resid }} & 0.092 \\
\hline Durbin-Watson & 1.839 & & \\
\hline
\end{tabular}

$\left({ }^{*}\right)$ Significant at $1 \%$.

\section{Appendix 2}

\section{Description of the GVAR methodology}

To give any economic interpretation to estimated VAR, traditional analysis revolved around the identification problem. Different analysts imposed various types of restrictions on the reduced form estimates of the VAR to recover the shocks of a structural model. Many alternatives to restrict the variance-covariance matrix of the errors of the reduced form estimates exist (i.e. Sims(1986), Bernanke (1986), Blanchard-Quah (1989)), but the most common ones use a Cholesky decomposition and/or particular economic models to restrict this matrix ${ }^{28}$. All of the above seek to recover a primitive set of structural shocks that are assumed to be independent and serially uncorrelated

Once these structural shocks are recovered, the impulse response functions can be interpreted in a meaningful way. The traditional impulse response analysis estimates the effects of a shock of size $\delta$ affecting the system at time $t$ on the system's state at time $t+n$ without any other shocks taking place during

${ }^{28}$ Canova (1995) has an excellent overview of VAR analysis and the multiple ways researchers deal with the identification problem. 
the transition. This estimation is performed by comparing two realizations of the system: one in which the system is shocked by a variable-specific shock (all other shocks are "turned off") and the other one (benchmark case) in which no shocks affect the system. In this setting of orthogonal shocks, the variance decomposition (defined as the proportion of the $n$-step ahead forecast error variance of variable $i$ which is accounted for by innovations in variable $j$ in the VAR) adds up to $100 \%$.

The traditional impulse response is :

$\mathrm{I}_{\mathrm{Y}}\left(\mathrm{n}, \delta, \omega_{\mathrm{t}-1}\right)=\mathrm{E}\left(\mathrm{Y}_{\mathrm{t}+\mathrm{n}} / \mathrm{V}_{\mathrm{t}}=\delta, \mathrm{V}_{\mathrm{t}+1}=0, \ldots \mathrm{V}_{\mathrm{t}+\mathrm{n}}=0, \omega_{\mathrm{t}-1}\right)-\mathrm{E}\left(\mathrm{Y}_{\mathrm{t}+\mathrm{n}} / \mathrm{V}_{\mathrm{t}}=0, \mathrm{~V}_{\mathrm{t}+1}=0, \ldots \quad \mathrm{V}_{\mathrm{t}+\mathrm{n}}\right.$ $\left.=0, \omega_{t-1}\right)$.

$\omega$ is the set of information

In the case of a multivariate linear system, such as the one we examine the impulse response function has the following form.

Consider a multivariate linear system $\mathrm{Y}_{\mathrm{t}}=\mathrm{AY} \mathrm{t}_{\mathrm{t}-1}+\mathrm{V}_{\mathrm{t}}$

Where $\mathrm{V}_{\mathrm{t}} \sim \mathrm{N}(0, \Sigma)$

Under very mild assumptions, the system has an infinite moving average representation,

$$
\underset{i}{Y_{i}}=\sum_{i=0}^{\infty} A_{i} \quad V_{t-i}
$$

For this case, the impulse response function is:

$\mathrm{I}_{\mathrm{Y}}\left(\mathrm{n}, \delta, \omega_{\mathrm{t}-1}\right)=\mathrm{E}\left(\mathrm{Y}_{\mathrm{t}+\mathrm{n}} / \mathrm{V}=\delta, \omega_{\mathrm{t}-1}\right)-\mathrm{E}\left(\mathrm{Y}_{\mathrm{t}+\mathrm{n}} / \omega_{\mathrm{t}-1}\right)$

$$
=\mathrm{A}_{\mathrm{n}} \delta
$$

Recall $\mathrm{V}$ is a vector of shocks and $\delta$ (the size of the shock) is $\delta=\left(\delta_{1}, \delta_{2}, \delta_{3}, \delta_{4} \ldots \delta_{\mathrm{m}}\right)$ '. Hence, the impulse response function depends on the composition of the shocks.

The choice of the particular vector of shocks, $\delta$, can be done several ways. One of them is by means of the Cholesky decomposition of $\Sigma$, such that: TT' $=\sum$, such that the shocks are orthogonalized. $\left(\varepsilon=\mathrm{T}^{-1} \mathrm{~V}\right)$

The effect of a unit shock at time $t$ to the $i$ th orthogonalized error $\varepsilon_{i t}$, on the $k$ th variable at time $t+N$ is given by:

$O I R_{i k, N}=e_{k}^{\prime} A_{N} T e_{i}, \quad i, k=1,2, \ldots, m$

where $e_{k}\left(e_{i}\right)$ is a selection vector with its $k$ th (ith) element equal to unity and zeroes elsewhere.

The matrix $T$ in the orthogonal IR function is of the form:

$T=\left(\begin{array}{cccc}\widetilde{\sigma}_{11}^{1 / 2} & 0 & \ldots & 0 \\ \vdots & \widetilde{\sigma}_{22}^{1 / 2} & \ldots & 0 \\ \vdots & \vdots & \ddots & 0 \\ \widetilde{\sigma}_{m 1}^{1 / 2} & \ldots & \ldots & \widetilde{\sigma}_{m m}^{1 / 2}\end{array}\right)$

Where the $\sim$ sign indicates that the variance corresponds to the transformed innovation vector $T^{-1} V_{t}$. Therefore, any alteration in the ordering will usually result in a different impulse responses for the $k$ th variable. 
KPP reconsider VAR analysis around two facts: a) shocks to different variable are not independent b) shocks are correlated across time ${ }^{29}$. The treatment of these two issues led them to examine system-wide shocks (as opposed to variable-specific) and to deal in some manner with future shocks given their autocorrelation. The way they did this was by means of the expectations operator conditional on history and/or shock. The constructed response averages out future shocks, hence it is an average of what might happen in the future given the past and present.

KPP's approach to avoid the composition problem is to fix one shock (one element of $\delta$ ) and integrating out the effects of other shocks using an assumed distribution of the errors or the historically observed one. In the linear case the distribution of the GI can be obtained from the distribution of $\mathrm{Vt}_{\text {. }}$ If $\mathrm{V}_{\mathrm{t}} \sim \mathrm{N}(0, \Sigma)$, then $\mathrm{GI} \sim \mathrm{N}\left(0, A \sum \mathrm{A}^{\prime}\right)$. The variances along the diagonal of $\mathrm{A}_{n} \sum \mathrm{A}_{n}$ ' measure the effect of shocking the system and then averaging the squares of the GI component by component against the joint distribution of the system-wide shocks.

The generalized impulse response for the $k$ th variable will be

$$
G I R_{i k, N}=\frac{e_{k}^{\prime} A_{N} \Sigma e_{i}}{\sqrt{\sigma_{i i}}}, \quad i, k=1,2, \ldots, m
$$

Where $\Sigma$ is the variance-covariance matrix of the original error vector $V_{\mathrm{t}}$, that is:

$\Sigma=E(V, V$,

that is,

$$
\Sigma=\left(\begin{array}{cccc}
\sigma_{11} & \sigma_{12} & \ldots & \sigma_{1 m} \\
\vdots & \sigma_{22} & \ldots & \vdots \\
\vdots & \vdots & \ddots & \vdots \\
\sigma_{m 1} & \ldots & \ldots & \sigma_{m m}
\end{array}\right)
$$

So the GIR is invariant to the ordering of the variables in the VAR.

KPP show that in the case where the vector of random shocks is jointly normally distributed, the GI response to a shock of size equivalent to one standard deviation to the ith disturbance term is equal to

$$
\mathrm{A}_{\mathrm{n}} \eta_{\mathrm{i}} \mathrm{e}_{\mathrm{k}}\left(\sigma_{\mathrm{ii}}\right)^{-1 / 2}
$$

Where $\eta_{\mathrm{i}}=\mathrm{E}\left(\mathrm{V}_{\mathrm{t}} \mathrm{V}_{\mathrm{it}}\right)$ and $\sigma_{\mathrm{ii}}=\mathrm{E}\left(\mathrm{V}^{2}\right)$

Summing up, the GI produces an expression that is independent of the ordering or any other a-priori restrictions. Similarly the GVAR does mot pretend to recover any structural shocks. The analysis describes how the system behaves after a specific historical shock. Since historical shocks are not orthogonal, they do not add up to $100 \%$.

\footnotetext{
${ }^{29}$ They consider a third issue which is the state of the system prior to the shock and afterwards, but we do not examine this complication here since it applies only to non-linear systems.
} 


\section{Appendix 3 \\ Variable Description and Summary of VAR estimates for each country}

\section{Argentina-}

TOT-A composite index of the major commodities was constructed and the deflated by the US consumer price index. The commodities (and weights ) were: Beef (21\%), wheat (42\%), soybean (37\%). The source for this monthly data was The World Bank, DECPG website. The consumer price index in the United States is obtained from the Federal Reserve Board.

Spreads- Argentina sovereign Brady bond spreads. Source: JP Morgan. Monthly since 1993.

Real Interest rate- Calculated with a nominal interest rate, the Argentina Money market Rate, source IFS. Expected inflation is estimated with an ARIMA model for the monthly seasonally adjusted data and taking the fitted value.

Real Exchange Rate- Source IFS

Output- Index of Industrial Produ:tion. Source:

\section{Brazil}

TOT-Constructed as the ratio of the export price index to the import price index. Source of both indeces: Datastream.

Spreads- Brazilian sovereign Brady bond spreads. Source: JP Morgan. Monthly since 1991.

Real Interest rate- Calculated with a nominal interest rate,the Brazil Money market Rate, source IFS. Expected inflation is estimated with an ARIMA model for the monthly seasonally adjusted data and taking the fitted value.

Real Exchange Rate- Source IFS

Output- Index of Industrial Production. Source:

\section{Mexico}

TOT-Two indicators were used. A terms of trade variable computed by the central bank, and the price of the West Texas Intermediate deflated by the US consumer price index. The latter variable gave better results.

Spreads- Mexican sovereign Brady bond spreads. Source: JP Morgan. Monthly since 1991.

Real Interest rate- Calculated with a nominal interest rate, the Mexican Money market Rate, source IFS. Expected inflation is estimated with an ARIMA model for the monthly seasonally adjusted data and taking the fitted value.

Real Exchange Rate- Source IFS

Output- Index of Industrial Production. Source:

Chile

TOT- The price of copper deflated by the US consumer price index was used as a terms of trade proxy. Spreads- Latin sovereign Brady bond spreads. Source: JP Morgan. Monthly since 1991.

Real Interest rate- Calculated with a nominal interest rate, the Deposit Rate, source IFS. Expected inflation is estimated with an ARIMA model for the monthly seasonally adjusted data and taking the fitted value.

Real Exchange Rate- Source IFS

\section{Colombia}

TOT-Two indicators were used. A terms of trade variable computed as a weighted index of the major commodity exports and the price of the West Texas Intermediate deflated by the US consumer price index. The latter variable gave better results.

Spreads- Latin sovereign Brady bond spreads. Source: JP Morgan. Monthly since 1991.

Real Interest rate- Calculated with a nominal interest rate, the Colombia Discount Rate, source IFS. Expected inflation is estimated with an ARIMA model for the monthly seasonally adjusted data and taking the fitted value. 
Real Exchange Rate- Source IFS

Output- Index of Industrial Production. Source:

\section{Ecuador}

TOT- A terms of trade proxy was computed as a weighted average of the major commodity exports: oil, bananas, shrimp, coffee and cocoa. All the indexes were deflated by the US consumer price index.

Spreads- Latin sovereign Brady bond spreads. Source: JP Morgan. Monthly since 1991.

Real Interest rate- Calculated with a nominal interest rate, the Ecuador Discount Rate, source IFS. Expected inflation is estimated with an ARIMA model for the monthly seasonally adjusted data and taking the fitted value.

Real Exchange Rate- Source IFS

Output- Index of Industrial Production. Source:

Peru

TOT- The terms of trade computed by the central bank. Source: Table 52, Nota Semanal, BCRP.

Spreads- Latin sovereign Brady bond spreads. Source: JP Morgan. Monthly since 1991.

Real Interest rate- Calculated with a nominal interest rate, the Peru Discount Rate, source IFS. Expected inflation is estimated with an ARIMA model for the monthly seasonally adjusted data and taking the fitted value.

Real Exchange Rate- Source IFS

Output- Index of Industrial Production. Source:

\section{Venezuela}

TOT- A terms of trade proxy was computed as a weighted average of the major commodity exports: oil, iron, gold, aluminum and steel. All the indexes were deflated by the US consumer price index.

Spreads- Venezuela sovereign Brady bond spreads. Source: JP Morgan. Monthly since 1991.

Real Interest rate- Calculated with a nominal interest rate, the Venezuela Discount Rate, source IFS. Expected inflation is estimated with an ARIMA model for the monthly seasonally adjusted data and taking the fitted value.

Real Exchange Rate- Source IFS

Output- Index of Industrial Production. Source:

All the variables are first-order differenced, except the real interest rate and output growth rates. Real interest rates are differenced in Chile's case, and so is output growth in Peru.

\begin{tabular}{|c|c|c|c|c|c|}
\hline Argentina & TOT & Spreads & $\begin{array}{l}\text { Real Interest } \\
\text { rate }\end{array}$ & REER & Output \\
\hline Adj. $R^{2}$ & .01 & .04 & .05 & .35 & .63 \\
\hline S.E. & 4.1 & 149 & .04 & 1.64 & .058 \\
\hline \multicolumn{6}{|c|}{$\begin{array}{l}\text { Correlation of VAR } \\
\text { residuals with }\end{array}$} \\
\hline TOT & 1.0 & -.42 & -.18 & -.02 & .23 \\
\hline Spreads & & 1.0 & .47 & -.3 & -.32 \\
\hline Real interest rate & & & 1.0 & .17 & -.17 \\
\hline$\overline{R E E R}$ & & & & 1.0 & .16 \\
\hline Output & & & & & 1.0 \\
\hline
\end{tabular}




\begin{tabular}{|l|l|l|l|l|l|}
\hline Brazil & TOT & Spreads & $\begin{array}{l}\text { Real Interest } \\
\text { rate }\end{array}$ & REER & Output \\
\hline Adj. $\mathrm{R}^{2}$ & .27 & -.51 & .22 & -.36 & .79 \\
\hline S.E. & 2.31 & 151.7 & .21 & 2.57 & .03 \\
\hline $\begin{array}{l}\text { Correlation of VAR } \\
\text { residuals with }\end{array}$ & & & & & \\
\hline TOT & 1.0 & -.35 & -.01 & -.11 & .064 \\
\hline Spreads & & 1.0 & -.04 & -.47 & -.03 \\
\hline Real interest rate & & & 1.0 & -.19 & .08 \\
\hline REER & & & & 1.0 & .19 \\
\hline Output & & & & & 1.0 \\
\hline
\end{tabular}

\begin{tabular}{|l|l|l|l|l|l|}
\hline Chile & TOT & Spreads & $\begin{array}{l}\text { Real Interest } \\
\text { rate }\end{array}$ & REER & Output \\
\hline Adj. R $^{2}$ & -.06 & .09 & .58 & .027 & .43 \\
\hline S.E. & .88 & 112.4 & .029 & 2.13 & .044 \\
\hline $\begin{array}{l}\text { Correlation of VAR } \\
\text { residuals with }\end{array}$ & & & & & \\
\hline TOT & 1.0 & .24 & .11 & -.20 & .017 \\
\hline Spreads & & 1.0 & .08 & -.44 & -.06 \\
\hline Real interest rate & & & 1.0 & .05 & -.157 \\
\hline REER & & & & 1.0 & .04 \\
\hline Output & & & & & 1.0 \\
\hline
\end{tabular}

\begin{tabular}{|l|l|l|l|l|l|}
\hline Colombia & TOT & Spreads & $\begin{array}{l}\text { Real Interest } \\
\text { rate }\end{array}$ & REER & Output \\
\hline Adj. R $^{2}$ & -.34 & .42 & .81 & .45 & .64 \\
\hline S.E. & 12.3 & 89.5 & .02 & 2.5 & .036 \\
\hline $\begin{array}{l}\text { Correlation of VAR } \\
\text { residuals with }\end{array}$ & & & & & \\
\hline TOT & 1.0 & .30 & .35 & -.01 & -.37 \\
\hline Spreads & & 1.0 & .27 & -.33 & .05 \\
\hline Real interest rate & & & 1.0 & -.18 & -.38 \\
\hline REER & & & & 1.0 & -.41 \\
\hline Output & & & & & 1.0 \\
\hline
\end{tabular}

\begin{tabular}{|l|l|l|l|l|l|}
\hline Ecuador & TOT & Spreads & $\begin{array}{l}\text { Real Interest } \\
\text { rate }\end{array}$ & REER & Output \\
\hline Adj. $\mathrm{R}^{2}$ & .07 & -.41 & .32 & .14 & .99 \\
\hline S.E. & 9.1 & 139.7 & .08 & 3.57 & .002 \\
\hline $\begin{array}{l}\text { Correlation of VAR } \\
\text { residuals with }\end{array}$ & & & & & \\
\hline TOT & 1.0 & -.10 & .06 & .03 & .38 \\
\hline Spreads & & 1.0 & -.05 & -.01 & .01 \\
\hline Real interest rate & & & 1.0 & -.24 & -.09 \\
\hline REER & & & & & .08 \\
\hline Output & & & & & 1.0 \\
\hline
\end{tabular}




\begin{tabular}{|l|l|l|l|l|l|}
\hline Mexico & TOT & Spreads & $\begin{array}{l}\text { Real Interest } \\
\text { rate }\end{array}$ & REER & Output \\
\hline Adj. R $^{2}$ & .38 & .33 & .33 & -.02 & .66 \\
\hline S.E. & .005 & 116.9 & .06 & 4.78 & .04 \\
\hline $\begin{array}{l}\text { Correlation of VAR } \\
\text { residuals with }\end{array}$ & & & & & \\
\hline TOT & 1.0 & -.32 & -.2 & .13 & .20 \\
\hline Spreads & & 1.0 & 0.8 & -.8 & .10 \\
\hline Real interest rate & & & 1.0 & -.82 & .09 \\
\hline REER & & & & 1.0 & -.11 \\
\hline Output & & & & & 1.0 \\
\hline
\end{tabular}

\begin{tabular}{|l|l|l|l|l|l|}
\hline Peru & TOT & Spreads & $\begin{array}{l}\text { Real Interest } \\
\text { rate }\end{array}$ & REER & Output \\
\hline Adj. $\mathbf{R}^{2}$ & -.26 & .06 & .61 & .65 & .58 \\
\hline S.E. & 4.85 & 113 & .07 & 1.93 & .032 \\
\hline $\begin{array}{l}\text { Correlation of VAR } \\
\text { residuals with }\end{array}$ & & & & & \\
\hline TOT & 1.0 & -.30 & -.18 & .18 & .02 \\
\hline Spreads & & 1.0 & .34 & -.67 & -.13 \\
\hline Real interest rate & & & 1.0 & -.59 & .05 \\
\hline REER & & & & 1.0 & .20 \\
\hline Output & & & & & 1.0 \\
\hline
\end{tabular}

\begin{tabular}{|l|l|l|l|l|l|}
\hline Venezuela & TOT & Spreads & $\begin{array}{l}\text { Real Interest } \\
\text { rate }\end{array}$ & REER & Output \\
\hline Adj. R $^{2}$ & .17 & -.40 & .68 & .29 & .74 \\
\hline S.E. & 2.7 & 263 & .09 & 6.2 & .136 \\
\hline $\begin{array}{l}\text { Correlation of VAR } \\
\text { residuals with }\end{array}$ & & & & & \\
\hline TOT & 1.0 & -.06 & -.18 & -.52 & .14 \\
\hline Spreads & & 1.0 & -.13 & -.15 & -.20 \\
\hline Real interest rate & & & 1.0 & .06 & .05 \\
\hline REER & & & & 1.0 & -.015 \\
\hline Output & & & & & 1.0 \\
\hline
\end{tabular}




\begin{tabular}{|l|c|c|c|c|c|}
\hline \multicolumn{7}{|l|}{ Coefficient of Variation of the Different Variables used in the VAR models } \\
(standard deviation/mean)
\end{tabular}

\begin{tabular}{|l|c|c|c|c|c|c|c|c|}
\hline \multicolumn{8}{|c|}{ Coefficient of Variation of the Variables in Levels Breaking the Sample Period } \\
$1992-1996$ and 1997-1998 \\
\cline { 2 - 9 } & \multicolumn{2}{|c|}{ TOT } & \multicolumn{2}{c|}{ Spreads } & \multicolumn{2}{c|}{ Real Interest Rates } & \multicolumn{2}{c|}{ Real Exchange Rates } \\
\hline & $92-96$ & $97-98$ & $92-96$ & $97-98$ & $92-96$ & $97-98$ & $92-96$ & $97-98$ \\
\hline Argentina & .07 & .06 & .35 & .39 & 2.5 & .50 & .05 & .02 \\
\hline Brazil & .14 & .03 & .28 & .49 & 1.08 & .50 & .18 & .03 \\
\hline Chile & .16 & .17 & .34 & .47 & .96 & .50 & .06 & .02 \\
\hline Colombia & .12 & .20 & .34 & .47 & .50 & .50 & .10 & .05 \\
\hline Mexico & .12 & .20 & .46 & .45 & 1.37 & .85 & .17 & .04 \\
\hline
\end{tabular}




\section{Appendix 4 \\ Generalized Impulse Response Functions}

\section{Argentina}

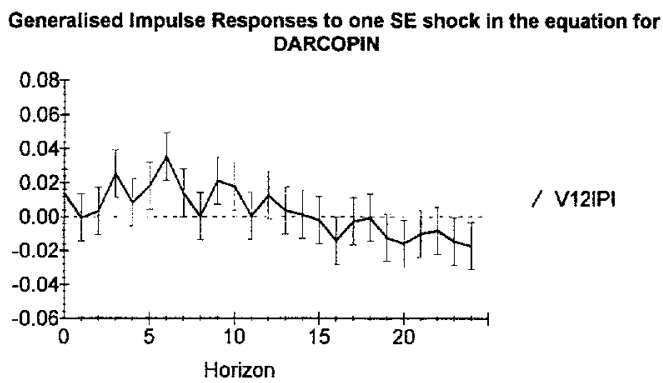

Generalised Impulse Responses to one SE shock in the equation for DARGEMBI

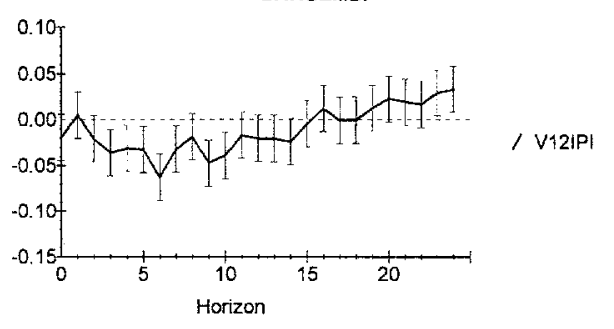

Generalised Impulse Responses to one SE shock in the equation for AREXANRE

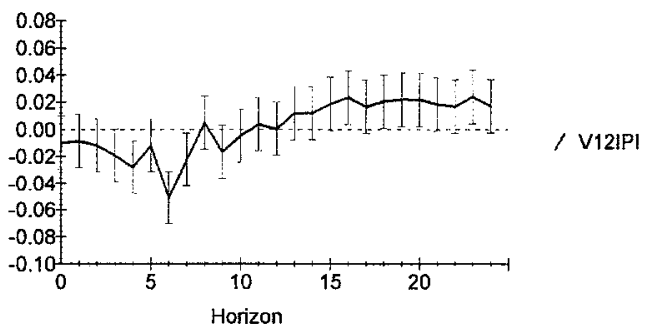

Generalised Impulse Responses to one SE shock in the equation for DARGREER

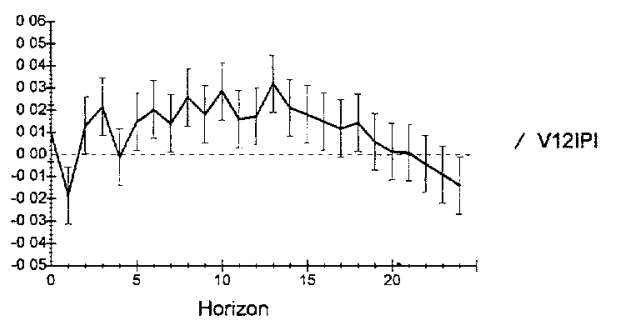




\section{Brazil}

Generalised Impulse Responses to one SE shock in the equation for DBRATOT2

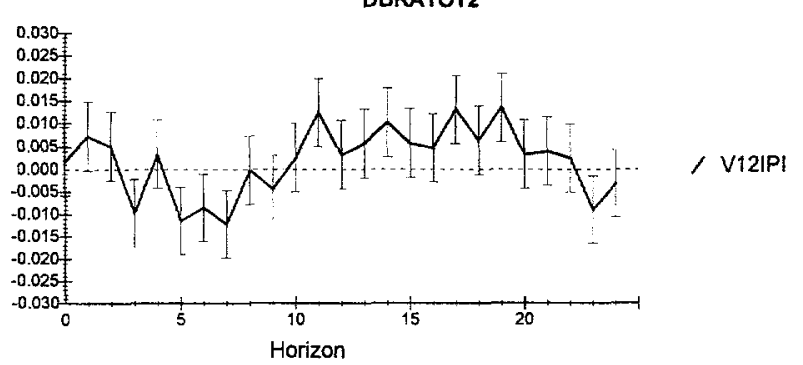

Generalised Impulse Responses to one SE shock in the equation for DBRAEMB

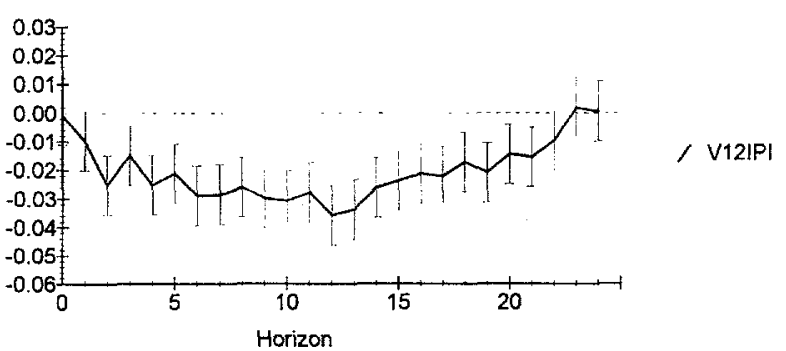

Generalised Impulse Responses to one SE shock in the equation for BREXANRE

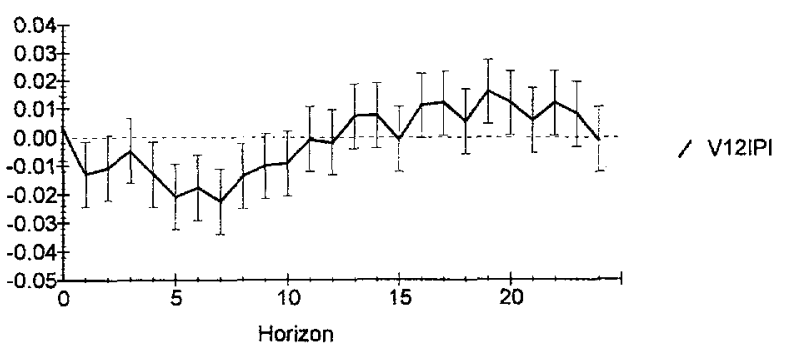

Generalised Impulse Responses to one SE shock in the equation for DBRAREER

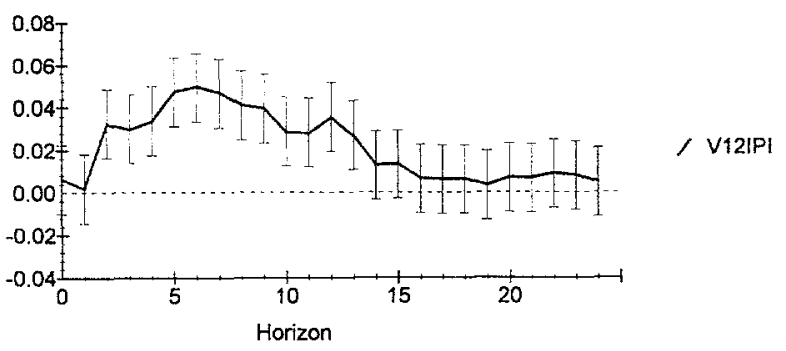


Chile Generalised Impulse Responses to one SE shock in the equation for
DPCOPRE

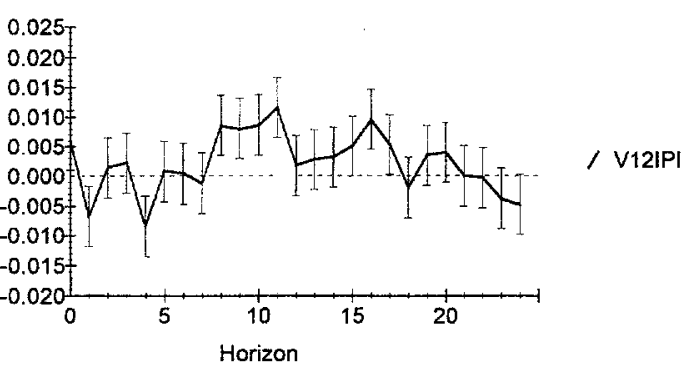

Generalised Impulse Respons : 3 to one SE shock in the equation for DLATEMBI

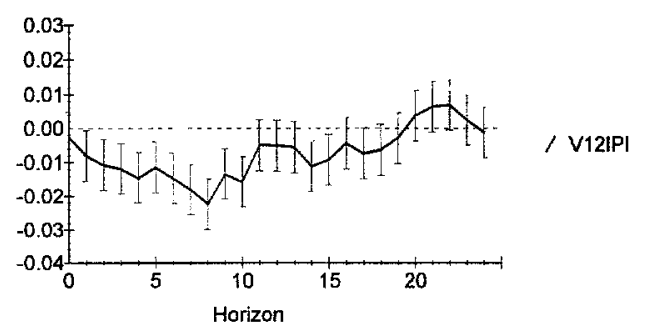

Generalised Impulse Responses to one SE shock in the equation for DCHEXANRE

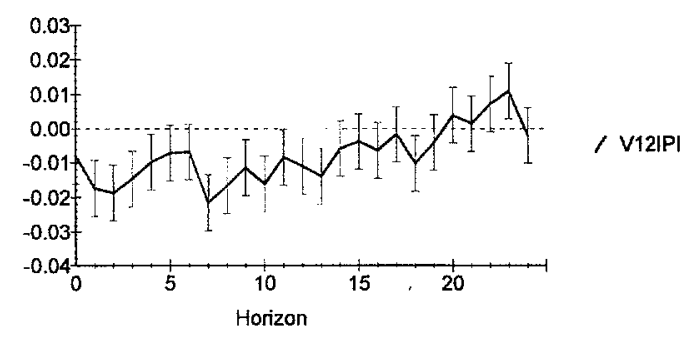

Generalised Impulse Responses to one SE shock in the equation for DCHLREER

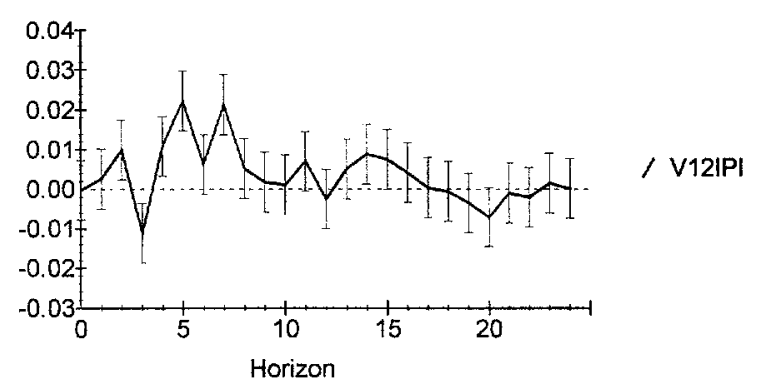


Mexico

Generalised Impulse Responses to one SE shock in the equation for DPWTIRE

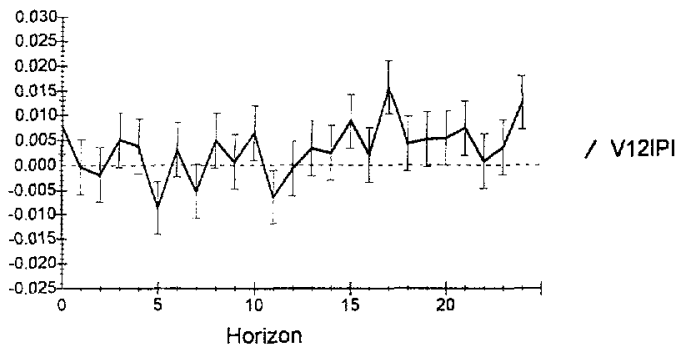

Generalised Impulse Responses to one SE shock in the equation for DMEXEMB!

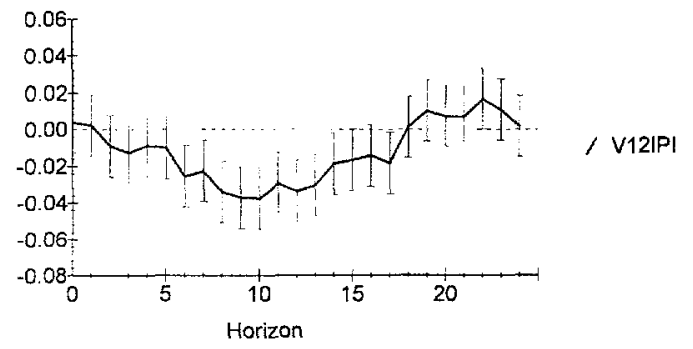

Generalised Impulse Responses to one SE shock in the equation for MXEXANR2

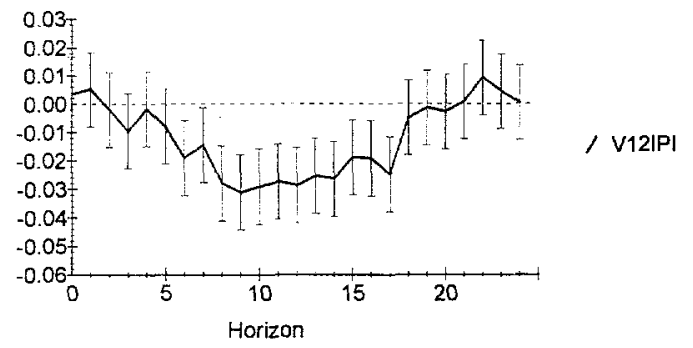

Generalised Impulse Responses to one SE shock in the equation for DMEXREER

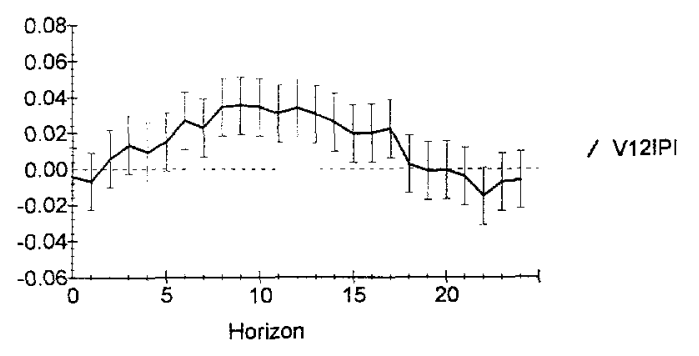




\section{Colombia}

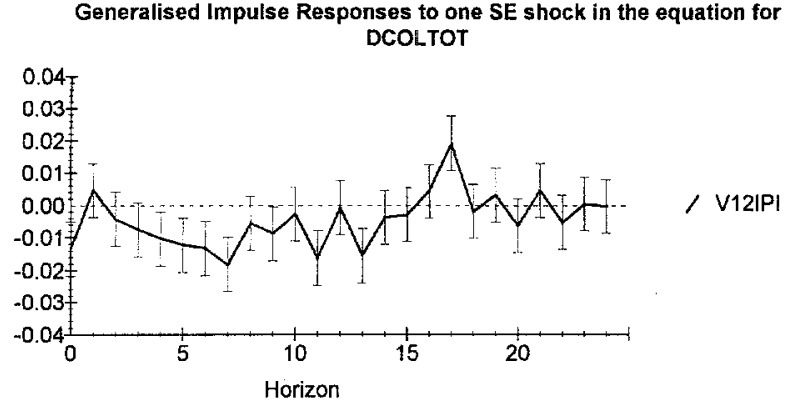

Generalised Impulse Responses to one SE shock in the equation for DLATEMBI

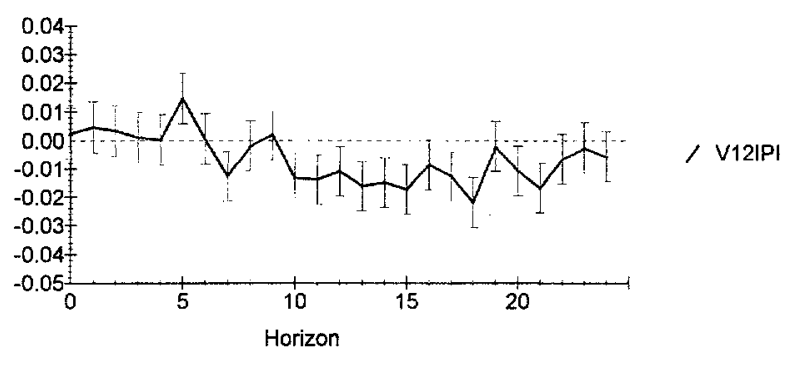

Generalised Impulse Responses to one SE shock in the equation for COEXANRE

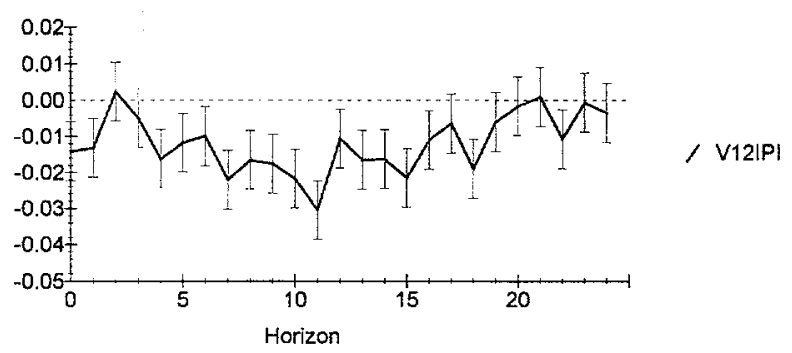

Generalised Impuise Responses to one SE shock in the equation for DCOLREER

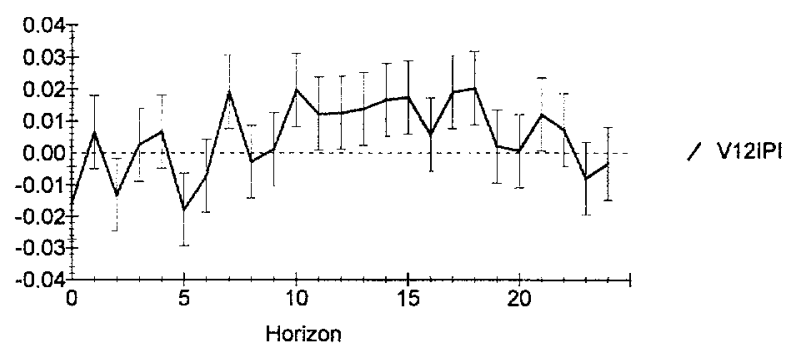




\section{Ecuador}

Generalised Impulse Responses to one SE shock in the equation for DEXPPRIM1

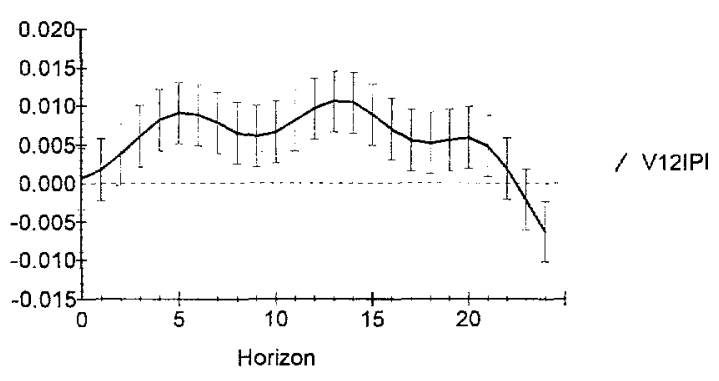

Generalised Impulse Responses to one SE shock in the equation for DLATEMBI

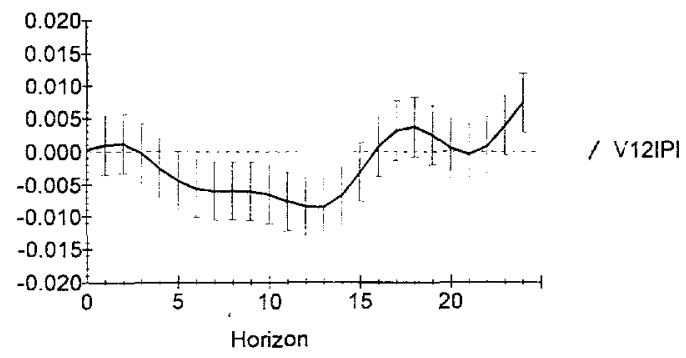

Generalised Impuise Responses to one SE shock in the equation for ECEXANRE

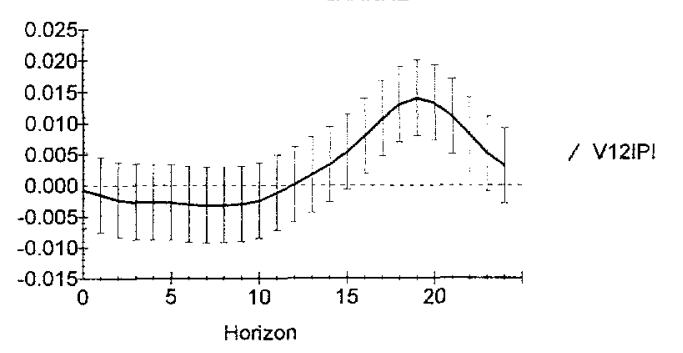

Generalised Impulse Responses to one SE shock in the equation for DECUREER

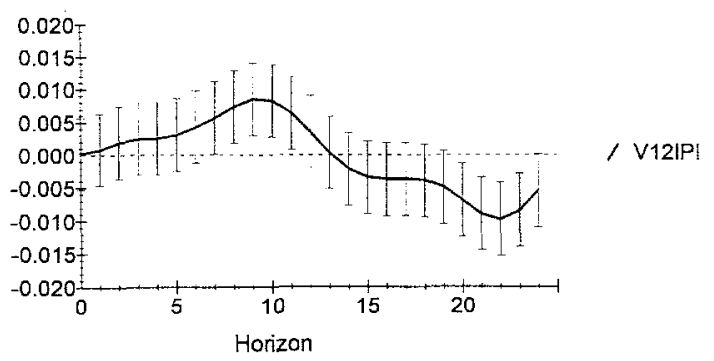




\section{Peru}

Generalised Impulse Responses to one SE shock in the equation for DPERTOT

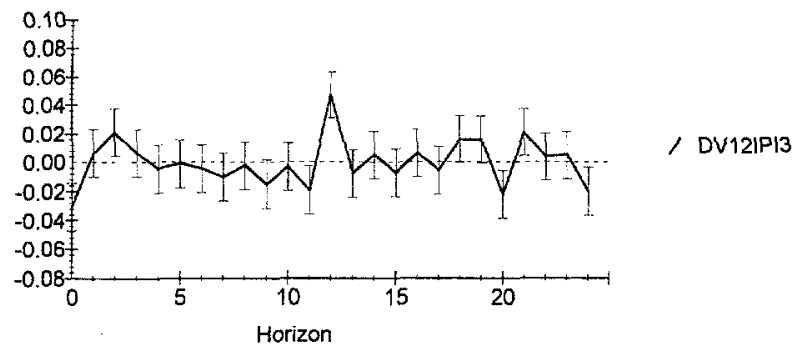

Generalised Impulse Responses to one SE shock in the equation for DLATEMBI

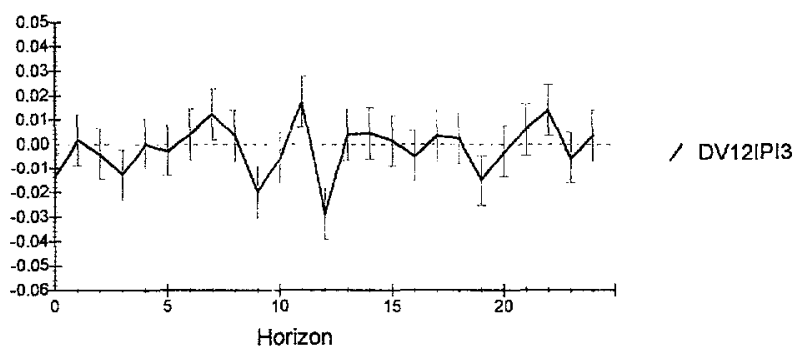

Generalised Impulse Responses to one SE shock in the equation for PEXANRE

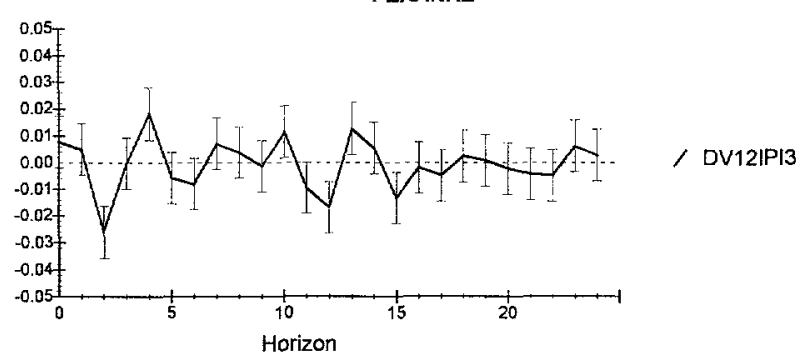

Generalised Impulse Responses to one SE shock in the equation for DPERREER

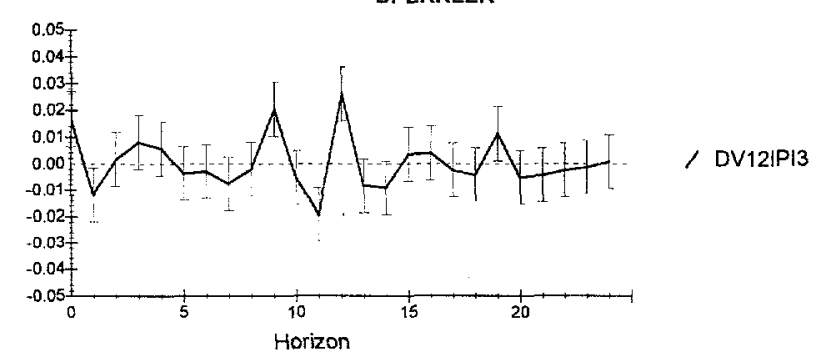




\section{Venezuela}

Generalised Impulse Responses to ane SE shock in the equation for DVENEXP

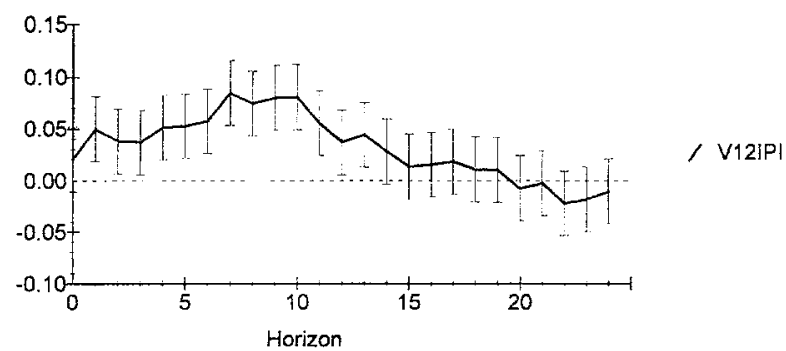

Generalised impulse Responses to one SE shock in the equation for DVENEMBI

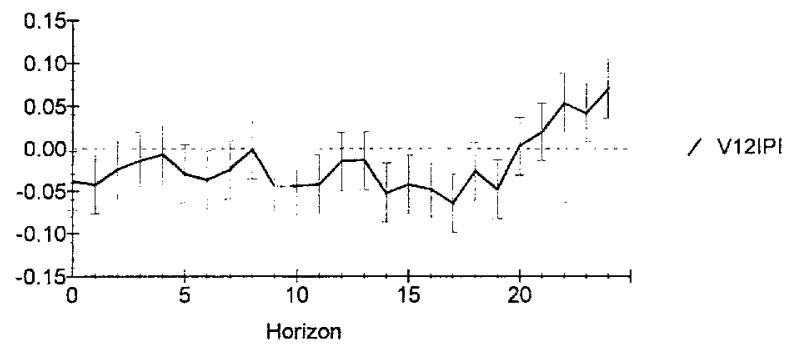

Generalised Impulse Responses to one SE shock in the equation for VEXANRE

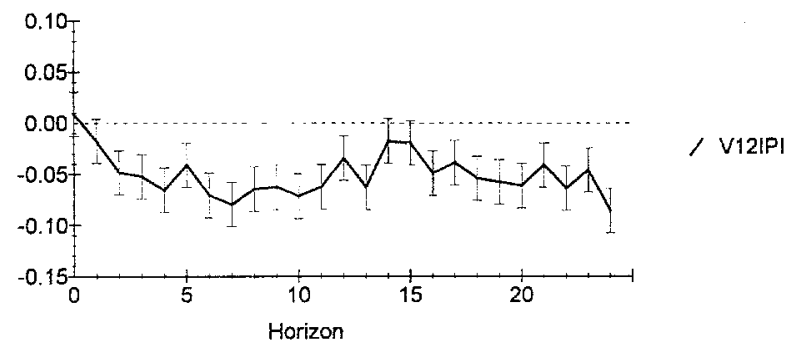

Generalised Impulse Responses to one SE shock in the equation for DVENREER

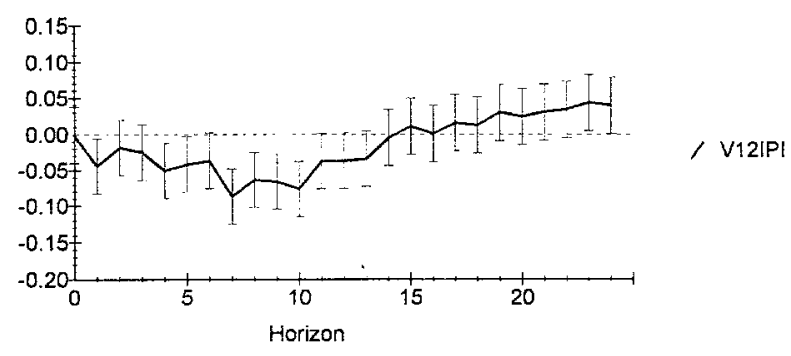




\section{Appendix 5 \\ Shock identification and persistence}

As mentioned in the text, shocks were defined as the difference between the projected values of the variables by means of the VAR and the observed levels, if the discrepancy exceeded two standard errors of the equation.

Argentina-

TOT- effect lasts 12 months; a shock of size 4.1 (positive) increases yearly growth rate by $1.3 \%$. Shocks Date and Size: 97:03 (2.9); 97:06 (-5.4); $97: 09$ (-5.7); 97:12 (4.4); 98:03 (-5.1); 98:06 (-6.4); 98:09 (-10.5); 98:12 (4.0); 99:03 (-15.1); 99:06 (-8.0)

Spreads - effect lasts 10 months; a 149 bps shock lowers yearly growth rate by $3.0 \%$.

Shocks date and size: 97:07(-295); 97:11 (+358) 98:02 (-417); 98:03 (+215); 98:06 (+610); 99:04 (-204) 99:05 (+476).

Real Interest Rate- effect lasts 7 months; a 4.8 percentage points shock lowers yearly growth rate by $1.8 \%$. Shocks date and size: 97:07 (-8.1); 97:12 (+10); 98:01 (-9.2); 98:05 (-9.5); 98:06 (+20); 99:01 (+11.5)

REER-effects last 18 mos; a 1.9 appreciating shock raises growth by $1.5 \%$.

Date and size: 97:02 (6.7); 97:05 (-5.4); 98:01 (-9); 98:03 (8); 98:07 (-4.7); 99:05 (4.6)

Brazil-

TOT- effect lasts 18 months; a shock of size 2.4 (appreciating) increases yearly growth rate by $0.2 \%$. Shocks Date and Size: $97: 03$ (-8.2); 97:06 (4.5); 97:09 (0); 97:12 (-2.4); 98:03 (3.5); 98:06 (-3.1); $98: 09$ ($1) ; 98: 12(-4.4) ; 99: 03(-10) ; 99: 06(-4.0)$

Spreads-effect lasts 21 months; a 150 bps shock lowers growth by $1.4 \%$.

Dates and size: 97:01 (-257); 97:05 (-342); $97: 06$ (282); 97:11 (258); 98:05 (317); 98:09 (516); 99:04 (631).

Real Interest Rates-Effect lasts 9 months; a .24 shock lowers growth by $.9 \%$

Dates and size: $97: 04(-.49) ; 97: 08(.5) ; 97: 12(.46) ; 98: 05(-.63)$ 98:07 (.61); 98:10(-.44); 98:12(.89); 99:02 $(-.72) ; 99: 05(.77) ; 99: 06(-.54)$

REER-Effect lasts one year; a 3.3 appreciating shock increases growth by $1 \%$.

Dates and sizes: 97:06(-4.3); $98: 06(5.3) ; 98: 09$ (-8.7); $98: 12(-6) ; 99: 01(-26) ; 99: 04(15)$.

Chile

TOT- effect lasts 17 months; a shock of size .8 lowers yearly growth rate by $0.3 \%$. Shocks Date and Size: 97:03 (2.5); $97: 06$ (1.5); $97: 09$ (-1.3); 97:12 (-2.5); 98:03 (-1.3); 98:06 (-0.1); 98:09 (-1.1); 98:12 (-0.7); 99:03 (-1.5); $99: 06(-0.4)$

Spreads- Effect lasts 15 months; a 118 bps shock lowers growth by $1.1 \%$.

Dates and size: 97:05 (-300); 98:02 (262); 98:05 (-215); 98:08 (534); 98:09 (-306); 99:04 (-452); 99:06 (292)

Real interest rate- effect lasts 13 months; a .033 shock lowers growth by $1.3 \%$

Dates and size: $97: 03$ (.096); 98:02 (.08); 98:04 (-.07); 98:09 (.104); 99:03 (-10)

REER-effect lasts 15 months; a 2.2 (appr) shock increases growth rate by $0.6 \%$

Dates and size: $97: 06(7.8) ; 98: 01(-5.1) ; 98: 02(5.7) ; 98: 07(-4.2) ; 98: 12(-6.1)$ 
Colombia

TOT- effect lasts 21 months; a shock of size 12 lowers yearly growth rate by $0.4 \%$. Shocks Date and Size: 97:03 (2.2); 97:06 (7.4); 97:09 (-21.3); 97:12 (4.3); $98: 03$ (-7.9); 98:06 (-4.9); 98:09 (-12.1); 98:12 (-0.2); $99: 03(-4.5) ; 99: 06(-2.0)$

Spreads-effect lasts 18 months; a 94 bps lowers growth by $0.4 \%$

Shocks date and size: 97:02 (-154); 97:06 (-254); 97:10 (290); 98:05(321); 98:07(-203); 98:09 (485); 99:04(-446).

Real interest rate-effect lasts 16 months; a .036 shock lowers growth rates by .014 .

Dates and size: 97:02(.069); 97:10(-.062); 97:11(.062); 98:08(.178); 98:11(.059); 99:06(-.19)

REER-effect lasts 18 months; a 2.4 shock lowers growth by $.6 \%$

Dates and size: $97: 03$ (6.3); 97:09 (-14.3) 97:11 (8.9) 98:01 (-14.3); 98:05(8.2): 98:09(-18.9); 98:10(7.9); 99:01 (-16.5); 99:03 (10)

Mexico

TOT- effect lasts 24 months; a shock of size .005 lowers yearly growth rate by $0.24 \%$. Shocks Date and Size: 97:03 (-.018); 97:06 (-.019); 97:09 (-.007); 97:12 (-.01); 98:03 (-.033); 98:06 (-.015); 98:09 (-0.0); 98:12 (-0.013); $99: 03(.01) ; 99: 06(.035)$

Spreads-effect lasts 18 months; a 117 bps lowers growth by $1.6 \%$

Shocks date and size: 97:01 (-295); 97:05 (+170); 97:07 (-360); 97:10 (+308); 98:01(+250); 98:07(-278); 98:09(+591); 99:01(-370).

Real interest rate-effect lasts 17 months; a .057 shock lowers growth rates by $.6 \%$.

Dates and size: 97:04(-.173); 97:11(+.152); 98:04 (-.105) 98:09(+.292); 99.01(-.10); 99:02(+.19)

REER-effect lasts 24 months; a 2.4 appreciating shock increases growth by $1.2 \%$

Dates and size: $97: 03(13.4)$; 97:05 (-15.6); $97: 07(+13)$ 97:10 (-9.6); $97: 11(8.9)$ 98:04 (+15) 98:09(-17.8); 99:01 $(+20)$ 
Table A5-1

Average Historical Shocks 1997-1999

(in standard deviation units of each variable)

\begin{tabular}{|c|c|c|c|c|}
\hline & Shocks to: & 1997 & 1998 & 1999 \\
\hline \multirow[t]{4}{*}{ Argentina } & TOT & -0.3 & -1.1 & -2.9 \\
\hline & Spreads & 0.2 & 1.0 & 3.5 \\
\hline & Real Interest Rate & 0.2 & 0.1 & 2.4 \\
\hline & Real Exchange Rate & 0.4 & -1.0 & 2.4 \\
\hline \multirow[t]{4}{*}{ Brazil } & TOT & -0.6 & -0.5 & -2.9 \\
\hline & Spreads & -0.1 & 2.8 & -4.2 \\
\hline & Real Interest Rate & 0.7 & 0.5 & -0.7 \\
\hline & Real Exchange Rate & -1.3 & -1.0 & -1.8 \\
\hline \multirow[t]{4}{*}{ Chile } & TOT & 0.1 & -4.0 & -2.4 \\
\hline & Spreads & -2.7 & 1.7 & -0.7 \\
\hline & Real Interest Rate & 2.8 & 1.1 & -2.9 \\
\hline & Real Exchange Rate & 3.8 & 1.2 & 0.0 \\
\hline \multirow[t]{4}{*}{ Colombia } & TOT & -0.2 & -0.5 & -0.3 \\
\hline & Spreads & -0.4 & 2.1 & -4.7 \\
\hline & Real Interest Rate & 0.6 & 3.3 & -5.3 \\
\hline & Real Exchange Rate & 0.1 & -1.8 & -2.7 \\
\hline \multirow[t]{4}{*}{ Mexico } & TOT & -2.8 & -3.1 & 4.5 \\
\hline & Spreads & -0.4 & 1.6 & -3.2 \\
\hline & Real Interest Rate & -0.2 & 1.6 & 0.8 \\
\hline & Real Exchange Rate & 0.8 & -0.6 & 8.3 \\
\hline
\end{tabular}




\section{Appendix 6 \\ Generalized Variance Decomposition of Real Interest Rates, Real Exchange Rates and External Spreads}

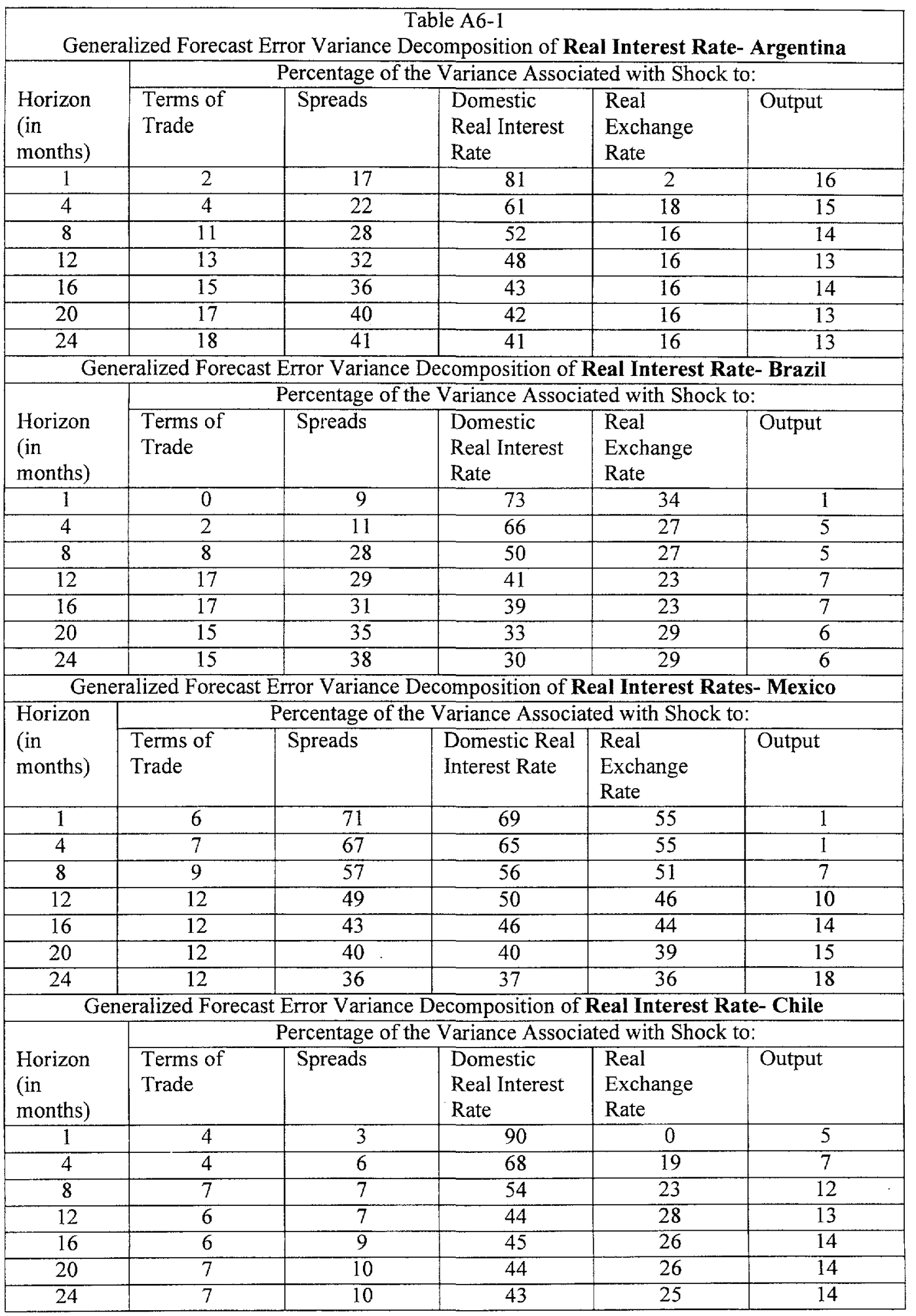




\begin{tabular}{|c|c|c|c|c|c|}
\hline \multicolumn{6}{|c|}{$\begin{array}{c}\text { Table A6-1 (Continued) } \\
\text { alized Forecast Error Variance Decomnosition of Real Interest R }\end{array}$} \\
\hline \multirow[b]{2}{*}{$\begin{array}{l}\text { Horizon } \\
\text { (in } \\
\text { months) }\end{array}$} & \multicolumn{5}{|c|}{ Percentage of the Variance Associated with Shock to: } \\
\hline & $\begin{array}{l}\text { Terms of } \\
\text { Trade }\end{array}$ & Spreads & $\begin{array}{l}\text { Domestic } \\
\text { Real Interest } \\
\text { Rate }\end{array}$ & $\begin{array}{l}\text { Real } \\
\text { Exchange } \\
\text { Rate }\end{array}$ & Output \\
\hline 1 & 9 & 5 & 94 & 1 & 28 \\
\hline 4 & 30 & 24 & 77 & 6 & 20 \\
\hline 8 & 23 & 24 & 81 & 7 & 19 \\
\hline 12 & 29 & 25 & 72 & 12 & 15 \\
\hline 16 & 27 & 26 & 70 & 12 & 14 \\
\hline 20 & 26 & 25 & 66 & 12 & 14 \\
\hline 24 & 30 & 24 & 62 & 11 & 13 \\
\hline \multicolumn{6}{|c|}{ Generalized Forecast Error Variance Decomposition of Real Interest Rate- Peru } \\
\hline \multirow[b]{2}{*}{$\begin{array}{l}\text { Horizon } \\
\text { (in } \\
\text { months) }\end{array}$} & \multicolumn{5}{|c|}{ Percentage of the Variance Associated with Shock to: } \\
\hline & $\begin{array}{l}\text { Terms of } \\
\text { Trade }\end{array}$ & Spreads & $\begin{array}{l}\text { Domestic } \\
\text { Real Interest } \\
\text { Rate }\end{array}$ & $\begin{array}{l}\text { Real } \\
\text { Exchange } \\
\text { Rate }\end{array}$ & Output \\
\hline 1 & 2 & 25 & 90 & 31 & 1 \\
\hline 4 & 8 & 33 & 74 & 39 & 2 \\
\hline 8 & 9 & 40 & 68 & 39 & 3 \\
\hline 12 & 20 & 44 & 56 & 30 & 6 \\
\hline 16 & 20 & 44 & 57 & 32 & 6 \\
\hline 20 & 22 & 46 & 54 & 31 & 6 \\
\hline 24 & 23 & 45 & 53 & 30 & 7 \\
\hline \multicolumn{6}{|c|}{ Generalized Forecast Error Variance Decomposition of Real Interest Rate Venezuela } \\
\hline \multirow[b]{2}{*}{$\begin{array}{l}\text { Horizon } \\
\text { (in } \\
\text { months) }\end{array}$} & \multicolumn{5}{|c|}{ Percentage of the Variance Associated with Shock to: } \\
\hline & $\begin{array}{l}\text { Terms of } \\
\text { Trade }\end{array}$ & Spreads & $\begin{array}{l}\text { Domestic } \\
\text { Real Interest } \\
\text { Rate }\end{array}$ & $\begin{array}{l}\text { Real } \\
\text { Exchange } \\
\text { Rate }\end{array}$ & Output \\
\hline 1 & 18 & 4 & 81 & 2 & 8 \\
\hline 4 & 36 & 4 & 43 & 21 & 25 \\
\hline 8 & 31 & 7 & 36 & 24 & 26 \\
\hline 12 & 24 & 7 & 28 & 19 & 39 \\
\hline 16 & 20 & 17 & 25 & 15 & 40 \\
\hline 20 & 18 & 16 & 27 & 14 & 39 \\
\hline 24 & 15 & 39 & 19 & 11 & 32 \\
\hline \multicolumn{6}{|c|}{ Generalized Forecast Error Variance Decomposition of Real Interest Rate- Ecuador } \\
\hline \multirow[b]{2}{*}{$\begin{array}{l}\text { Horizon } \\
\text { (in } \\
\text { months) }\end{array}$} & \multicolumn{5}{|c|}{ Percentage of the Variance Associated with Shock to: } \\
\hline & $\begin{array}{l}\text { Terms of } \\
\text { Trade }\end{array}$ & Spreads & $\begin{array}{l}\text { Domestic } \\
\text { Real Interest } \\
\text { Rate }\end{array}$ & $\begin{array}{l}\text { Real } \\
\text { Exchange } \\
\text { Rate }\end{array}$ & Output \\
\hline 1 & 1 & 2 & 94 & 4 & 11 \\
\hline 4 & 5 & 4 & 78 & 9 & 9 \\
\hline 8 & 4 & 22 & 61 & 10 & 5 \\
\hline 12 & 5 & 25 & 54 & 14 & 6 \\
\hline 16 & 5 & 33 & 47 & 11 & 6 \\
\hline 20 & 5 & 33 & 47 & 11 & 7 \\
\hline 24 & 6 & 33 & 47 & 11 & 6 \\
\hline
\end{tabular}




\begin{tabular}{|c|c|c|c|c|c|}
\hline \multicolumn{6}{|c|}{$\begin{array}{l}\text { Table A6-2 } \\
\text { Generalized Forecast Error Variance Decomposition of Spreads - Argentina }\end{array}$} \\
\hline \multirow[b]{2}{*}{$\begin{array}{l}\text { Horizon } \\
\text { (in } \\
\text { months) }\end{array}$} & \multicolumn{5}{|c|}{ Percentage of the Variance Associated with Shock to: } \\
\hline & $\begin{array}{l}\text { Terms of } \\
\text { Trade }\end{array}$ & Spreads & $\begin{array}{l}\text { Domestic } \\
\text { Real Interest } \\
\text { Rate }\end{array}$ & $\begin{array}{l}\text { Real } \\
\text { Exchange } \\
\text { Rate }\end{array}$ & Output \\
\hline 1 & 14 & 81 & 19 & 8 & 23 \\
\hline 4 & 15 & 62 & 22 & 17 & 20 \\
\hline 8 & 18 & 58 & 28 & 15 & 17 \\
\hline 12 & 22 & 58 & 26 & 14 & 16 \\
\hline 16 & 21 & 59 & 26 & 14 & 16 \\
\hline 20 & 22 & 60 & 25 & 15 & 17 \\
\hline 24 & 24 & 61 & 25 & 14 & 16 \\
\hline \multicolumn{6}{|c|}{ Generalized Forecast Error Variance Decomposition of Spreads - Brazil } \\
\hline \multirow[b]{2}{*}{$\begin{array}{l}\text { Horizon } \\
\text { (in } \\
\text { months) }\end{array}$} & \multicolumn{5}{|c|}{ Percentage of the Variance Associated with Shock to: } \\
\hline & $\begin{array}{l}\text { Terms of } \\
\text { Trade }\end{array}$ & Spreads & $\begin{array}{l}\text { Domestic } \\
\text { Real Interest } \\
\text { Rate }\end{array}$ & $\begin{array}{l}\text { Real } \\
\text { Exchange } \\
\text { Rate }\end{array}$ & Output \\
\hline 1 & 13 & 97 & 0 & 19 & 2 \\
\hline 4 & 12 & 89 & 4 & 19 & 3 \\
\hline 8 & 17 & 82 & 6 & 15 & 2 \\
\hline 12 & 17 & 77 & 7 & 16 & 3 \\
\hline 16 & 18 & 75 & 8 & 17 & 3 \\
\hline 20 & 18 & 73 & 8 & 17 & 4 \\
\hline 24 & 18 & 70 & 8 & 20 & 4 \\
\hline \multicolumn{6}{|c|}{ Generalized Forecast Error Variance Decomposition of Spreads -Mexico } \\
\hline \multirow{2}{*}{$\begin{array}{l}\text { Horizon } \\
\text { (in } \\
\text { months) }\end{array}$} & \multicolumn{5}{|c|}{ Percentage of the Variance Associated with Shock to: } \\
\hline & $\begin{array}{l}\text { Terms of } \\
\text { Trade }\end{array}$ & Spreads & $\begin{array}{l}\text { Domestic Real } \\
\text { Interest Rate }\end{array}$ & $\begin{array}{l}\text { Real } \\
\text { Exchange } \\
\text { Rate } \\
\end{array}$ & Output \\
\hline 1 & 10 & 89 & 52 & 54 & 8 \\
\hline 4 & 10 & 63 & 41 & 45 & 5 \\
\hline 8 & 10 & 57 & 39 & 37 & 11 \\
\hline 12 & 11 & 49 & 34 & 38 & 11 \\
\hline 16 & 13 & 49 & 30 & 35 & 11 \\
\hline 20 & 15 & 46 & 29 & 34 & 13 \\
\hline 24 & 16 & 45 & 29 & 34 & 14 \\
\hline \multicolumn{6}{|c|}{ Generalized Forecast Error Variance Decomposition of Spreads - Chile } \\
\hline \multirow[b]{2}{*}{$\begin{array}{l}\text { Horizon } \\
\text { (in } \\
\text { months) }\end{array}$} & \multicolumn{5}{|c|}{ Percentage of the Variance Associated with Shock to: } \\
\hline & $\begin{array}{l}\text { Terms of } \\
\text { Trade }\end{array}$ & Spreads & $\begin{array}{l}\text { Domestic } \\
\text { Real Interest } \\
\text { Rate } \\
\end{array}$ & $\begin{array}{l}\text { Real } \\
\text { Exchange } \\
\text { Rate } \\
\end{array}$ & Output \\
\hline 1 & 2 & 88 & 8 & 14 & 6 \\
\hline 4 & 9 & 72 & 8 & 17 & 9 \\
\hline 8 & 9 & 63 & 8 & 20 & 17 \\
\hline 12 & 9 & 57 & 10 & 19 & 16 \\
\hline 16 & 10 & 54 & 12 & 19 & 16 \\
\hline 20 & 10 & 51 & 13 & 18 & 15 \\
\hline 24 & 10 & 51 & 14 & 18 & 15 \\
\hline
\end{tabular}




\begin{tabular}{|c|c|c|c|c|c|}
\hline \multicolumn{6}{|c|}{$\begin{array}{l}\text { Table A6-2 (Continued) } \\
\text { Generalized Forecast Error Variance Decomposition of Spreads - Colombia }\end{array}$} \\
\hline \multirow[b]{2}{*}{$\begin{array}{l}\text { Horizon } \\
\text { (in } \\
\text { months) }\end{array}$} & \multicolumn{5}{|c|}{ Percentage of the Variance Associated with Shock to: } \\
\hline & $\begin{array}{l}\text { Terms of } \\
\text { Trade }\end{array}$ & Spreads & $\begin{array}{l}\text { Domestic } \\
\text { Real Interest } \\
\text { Rate }\end{array}$ & $\begin{array}{l}\text { Real } \\
\text { Exchange } \\
\text { Rate } \\
\end{array}$ & Output \\
\hline 1 & 79 & 83 & 25 & 13 & 1 \\
\hline 4 & 13 & 68 & 18 & 22 & 8 \\
\hline 8 & 37 & 44 & 15 & 13 & 11 \\
\hline 12 & 36 & 41 & 14 & 21 & 13 \\
\hline 16 & 37 & 41 & 13 & 22 & 12 \\
\hline 20 & 30 & 36 & 21 & 28 & 11 \\
\hline 24 & 32 & 32 & 21 & 28 & 10 \\
\hline \multicolumn{6}{|c|}{ Generalized Forecast Error Variance Decomposition of Spreads - Peru } \\
\hline & \multicolumn{5}{|c|}{ Percentage of the Variance Associated with Shock to: } \\
\hline $\begin{array}{l}\text { Horizon } \\
\text { (in } \\
\text { months) }\end{array}$ & $\begin{array}{l}\text { Terms of } \\
\text { Trade }\end{array}$ & Spreads & $\begin{array}{l}\text { Domestic } \\
\text { Real Interest } \\
\text { Rate }\end{array}$ & $\begin{array}{l}\text { Real } \\
\text { Exchange } \\
\text { Rate }\end{array}$ & Output \\
\hline 1 & 5 & 83 & 13 & 44 & 8 \\
\hline 4 & 9 & 72 & 14 & 40 & 15 \\
\hline 8 & 10 & 72 & 13 & 41 & 15 \\
\hline 12 & 23 & 56 & 11 & 32 & 24 \\
\hline 16 & 24 & 53 & 10 & 31 & 24 \\
\hline 20 & 25 & 52 & 9 & 31 & 24 \\
\hline 24 & 27 & 50 & 9 & 29 & 25 \\
\hline \multicolumn{6}{|c|}{ Generalized Forecast Error Variance Decomposition of Spreads - Venezuela } \\
\hline & \multicolumn{5}{|c|}{ Percentage of the Variance Associated with Shock to: } \\
\hline $\begin{array}{l}\text { Horizon } \\
\text { (in } \\
\text { months) }\end{array}$ & $\begin{array}{l}\text { Terms of } \\
\text { Trade }\end{array}$ & Spreads & $\begin{array}{l}\text { Domestic } \\
\text { Real Interest } \\
\text { Rate }\end{array}$ & $\begin{array}{l}\text { Real } \\
\text { Exchange } \\
\text { Rate }\end{array}$ & Output \\
\hline 1 & 6 & 65 & 3 & 13 & 6 \\
\hline 4 & 12 & 71 & 3 & 15 & 22 \\
\hline 8 & 11 & 64 & 6 & 16 & 22 \\
\hline 12 & 12 & 62 & 6 & 17 & 21 \\
\hline 16 & 12 & 62 & 6 & 17 & 20 \\
\hline 20 & 13 & 62 & 5 & 14 & 28 \\
\hline 24 & 13 & 56 & 6 & 13 & 33 \\
\hline \multicolumn{6}{|c|}{ Generalized Forecast Error Variance Decomposition of Spreads - Ecuador } \\
\hline \multirow[b]{2}{*}{$\begin{array}{l}\text { Horizon } \\
\text { (in } \\
\text { months) }\end{array}$} & \multicolumn{5}{|c|}{ Percentage of the Variance Associated with Shock to: } \\
\hline & $\begin{array}{l}\text { Terms of } \\
\text { Trade }\end{array}$ & Spreads & $\begin{array}{l}\text { Domestic } \\
\text { Real Interest } \\
\text { Rate }\end{array}$ & $\begin{array}{l}\text { Real } \\
\text { Exchange } \\
\text { Rate }\end{array}$ & Output \\
\hline 1 & 1 & 95 & 4 & 3 & $\overline{2}$ \\
\hline 4 & 5 & 86 & 1 & 7 & 2 \\
\hline 8 & 4 & 76 & 2 & 12 & 6 \\
\hline 12 & 5 & 70 & 5 & 14 & 6 \\
\hline 16 & 6 & 62 & 12 & 15 & 5 \\
\hline 20 & 6 & 57 & 11 & 18 & 7 \\
\hline 24 & 6 & 57 & 12 & 17 & 7 \\
\hline
\end{tabular}


Table A6-3

Generalized Variance Decomposition of Real Exchange Rate -Argentina

\begin{tabular}{|c|c|c|c|c|c|}
\hline \multirow[b]{2}{*}{$\begin{array}{l}\text { Horizon } \\
\text { (in } \\
\text { months) }\end{array}$} & \multicolumn{5}{|c|}{ Percentage of the Variance Associated with Shock to: } \\
\hline & $\begin{array}{l}\text { Terms of } \\
\text { Trade }\end{array}$ & Spreads & $\begin{array}{l}\text { Domestic } \\
\text { Real Interest } \\
\text { Rate }\end{array}$ & $\begin{array}{l}\text { Real } \\
\text { Exchange } \\
\text { Rate }\end{array}$ & Output \\
\hline 1 & 1 & 26 & 5 & 80 & 9 \\
\hline 4 & 6 & $\overline{23}$ & 11 & 62 & 12 \\
\hline 8 & 14 & 21 & 26 & 40 & 12 \\
\hline 12 & 15 & 28 & 25 & 38 & 13 \\
\hline 16 & 16 & 31 & 23 & 38 & 12 \\
\hline 20 & 18 & 32 & 25 & 35 & 11 \\
\hline 24 & 18 & 32 & 24 & 35 & 12 \\
\hline
\end{tabular}

Generalized Variance Decomposition of Real Exchange Rate- Brazil

\begin{tabular}{|c|c|c|c|c|c|}
\hline \multirow{2}{*}{$\begin{array}{l}\text { Horizon } \\
\text { in } \\
\text { months })\end{array}$} & $\begin{array}{l}\text { Terms of } \\
\text { Trade }\end{array}$ & Spreads & $\begin{array}{l}\text { Domestic } \\
\text { Real Interest } \\
\text { Rate }\end{array}$ & $\begin{array}{l}\text { Real } \\
\text { Exchange } \\
\text { Rate }\end{array}$ & Output \\
\hline 1 & 2 & 25 & 6 & 95 & 4 \\
\hline 4 & 4 & 28 & 10 & 79 & 10 \\
\hline 8 & 7 & 28 & 13 & 73 & 10 \\
\hline 12 & 9 & 37 & 11 & 65 & 9 \\
\hline 16 & 11 & 41 & 11 & 59 & 8 \\
\hline 20 & 11 & 43 & 11 & 56 & 8 \\
\hline 24 & 11 & 41 & 10 & 56 & 8 \\
\hline
\end{tabular}

Generalized Forecast Error Variance Decomposition of Real Exchange Rate- Mexico

\begin{tabular}{|c|c|c|c|c|c|}
\hline \multirow{2}{*}{$\begin{array}{l}\text { Horizon } \\
\text { (in } \\
\text { months) }\end{array}$} & \multicolumn{5}{|c|}{ Percentage of the Variance Associated with Shock to: } \\
\hline & $\begin{array}{l}\text { Terms of } \\
\text { Trade }\end{array}$ & Spreads & $\begin{array}{l}\text { Domestic Real } \\
\text { Interest Rate }\end{array}$ & $\begin{array}{l}\text { Real } \\
\text { Exchange } \\
\text { Rate }\end{array}$ & Output \\
\hline 1 & 5 & 62 & 52 & 82 & 5 \\
\hline 4 & 10 & 52 & 42 & 65 & 9 \\
\hline 8 & 12 & 47 & 40 & 53 & 12 \\
\hline 12 & 13 & 45 & 39 & 53 & 11 \\
\hline 16 & 13 & 43 & 36 & 47 & 13 \\
\hline 20 & 13 & 40 & 33 & 44 & 15 \\
\hline 24 & 13 & 38 & 32 & 42 & 16 \\
\hline
\end{tabular}

Generalized Forecast Error Variance Decomposition of Real Exchange Rate- Chile

\begin{tabular}{|c|c|c|c|c|c|}
\hline \multirow{2}{*}{$\begin{array}{l}\text { Horizon } \\
\text { in } \\
\text { months) }\end{array}$} & $\begin{array}{l}\text { Terms of } \\
\text { Trade }\end{array}$ & Spreads & $\begin{array}{l}\text { Domestic } \\
\text { Real Interest } \\
\text { Rate }\end{array}$ & $\begin{array}{l}\text { Real } \\
\text { Exchange } \\
\text { Rate }\end{array}$ & Output \\
\hline 1 & 6 & 27 & 2 & 88 & 2 \\
\hline 4 & 8 & 26 & 4 & 75 & 8 \\
\hline 8 & 13 & 30 & 5 & 64 & 14 \\
\hline 12 & 12 & 31 & 6 & 61 & 15 \\
\hline 16 & 13 & 31 & 7 & 58 & 15 \\
\hline 20 & 12 & 33 & 6 & 56 & 15 \\
\hline 24 & 13 & 33 & 7 & 55 & 14 \\
\hline
\end{tabular}




\begin{tabular}{|c|c|c|c|c|c|}
\hline \multicolumn{6}{|c|}{$\begin{array}{c}\text { Table A6-3 (Continued) } \\
\text { Generalized Variance Decomposition of Real Exchange Rate- Colombia }\end{array}$} \\
\hline \multirow[b]{2}{*}{$\begin{array}{l}\text { Horizon } \\
\text { (in } \\
\text { months) }\end{array}$} & \multicolumn{5}{|c|}{ Percentage of the Variance Associated with Shock to: } \\
\hline & $\begin{array}{l}\text { Terms of } \\
\text { Trade }\end{array}$ & Spreads & $\begin{array}{l}\text { Domestic } \\
\text { Real Interest } \\
\text { Rate }\end{array}$ & $\begin{array}{l}\text { Real } \\
\text { Exchange } \\
\text { Rate }\end{array}$ & Output \\
\hline 1 & 1 & 30 & 3 & 81 & 16 \\
\hline 4 & 7 & 24 & 17 & 49 & 15 \\
\hline 8 & 10 & 18 & 25 & 32 & 17 \\
\hline 12 & 15 & 23 & 22 & 29 & 18 \\
\hline 16 & 15 & 21 & 22 & 30 & 19 \\
\hline 20 & 22 & 21 & 20 & 25 & 14 \\
\hline 24 & 27 & 19 & 20 & 20 & 12 \\
\hline \multicolumn{6}{|c|}{ Generalized Variance Decomposition of Real Exchange Rate- Peru } \\
\hline \multicolumn{6}{|c|}{ Percentage of the Variance Associated with Shock to: } \\
\hline $\begin{array}{l}\text { Horizon } \\
\text { (in } \\
\text { months). }\end{array}$ & $\begin{array}{l}\text { Terms of } \\
\text { Trade }\end{array}$ & Spreads & $\begin{array}{l}\text { Domestic } \\
\text { Real Interest } \\
\text { Rate }\end{array}$ & $\begin{array}{l}\text { Real } \\
\text { Exchange } \\
\text { Rate }\end{array}$ & Output \\
\hline 1 & 3 & 54 & 15 & 92 & 5 \\
\hline 4 & 6 & 47 & 23 & 74 & 4 \\
\hline 8 & 12 & 36 & 22 & 57 & 17 \\
\hline 12 & 21 & 36 & 21 & 49 & 18 \\
\hline 16 & 29 & 34 & 18 & 43 & 19 \\
\hline 20 & 31 & 34 & 18 & 38 & 19 \\
\hline 24 & 32 & 33 & 17 & 37 & 20 \\
\hline \multicolumn{6}{|c|}{ Generalized Variance Decomposition of Real Exchange Rate- Venezuela } \\
\hline \multirow[b]{2}{*}{$\begin{array}{l}\text { Horizon } \\
\text { (in } \\
\text { months) }\end{array}$} & \multirow{2}{*}{\multicolumn{2}{|c|}{ Percentage }} & Variance Assoc & ed with Sho & \multirow{2}{*}{ Output } \\
\hline & & & $\begin{array}{l}\text { Domestic } \\
\text { Real Interest } \\
\text { Rate }\end{array}$ & $\begin{array}{l}\text { Real } \\
\text { Exchange } \\
\text { Rate }\end{array}$ & \\
\hline 1 & 34 & 1 & 1 & 94 & 1 \\
\hline 4 & 28 & 5 & 2 & 77 & 14 \\
\hline 8 & 17 & 42 & 5 & 35 & 12 \\
\hline 12 & 14 & 39 & 7 & 28 & 27 \\
\hline 16 & 15 & 37 & 8 & 27 & 28 \\
\hline 20 & 14 & 46 & 8 & 23 & 26 \\
\hline 24 & 11 & 50 & 7 & 18 & 30 \\
\hline \multicolumn{6}{|c|}{ Generalized Variance Decomposition of Real Exchange Rate- Ecuador } \\
\hline \multirow[b]{2}{*}{$\begin{array}{l}\text { Horizon } \\
\text { (in } \\
\text { months) }\end{array}$} & \multicolumn{5}{|c|}{ Percentage of the Variance Associated with Shock to: } \\
\hline & $\begin{array}{l}\text { Terms of } \\
\text { Trade }\end{array}$ & Spreads & $\begin{array}{l}\text { Domestic } \\
\text { Real Interest } \\
\text { Rate }\end{array}$ & $\begin{array}{l}\text { Real } \\
\text { Exchange } \\
\text { Rate }\end{array}$ & Output \\
\hline 1 & 0 & 12 & 6 & 82 & 1 \\
\hline 4 & 6 & 24 & 9 & 57 & 2 \\
\hline 8 & 10 & 28 & 9 & 47 & 9 \\
\hline 12 & 9 & 30 & 10 & 46 & 8 \\
\hline 16 & 9 & 31 & 10 & 45 & 7 \\
\hline 20 & 10 & 31 & 10 & 43 & 7 \\
\hline 24 & 9 & 32 & 11 & 41 & 7 \\
\hline
\end{tabular}




\section{Appendix 7}

Correlation Between VAR Forecast Errors and Potentially Important Omitted Variables

The issue of model specification is treated in some detail in Appendix 8, but only pertaining to a single variable: the choice between spreads (prices) or capital flows (quantities) to capture the international credit markets. However, the set of variables that could be potentially important determining output fluctuations is very long. Such is the case of fiscal-related variables such as the fiscal deficit or public expenditure. Other variables that could be important were related to financial market variables different than the real interest rate, like the growth of domestic credit to the private sector, trying to capture availability of funds. Similarly, the current account balance of the country captures financing by the rest of the world. Financial vulnerability could also be important and we used the change in short term debt or the change in the M2/Reserves ratio.

We narrowed the choice to a few of these variables, given the small sample limitations. Since some of these variables are recorded with a different frequency (annual or quarterly) we adopted a suggestive testing strategy, consisting of estimating the (annual average) forecast errors of the VAR models (actual values minus forecasted values) for each country and performed rank correlations of these errors with each of the potentially important omitted variables. This method would show any systematic correlation between our model overpredicting or underpredicting growth in those cases where, say, government expenditure growth was high or low, or current account deficits were high or low, etc.

Since this set of variables could be affected by the same set of variables that were used to forecast growth (TOT, spreads, real interest rates, real exchange rates and lagged growth) we attempted to correct for this endogeneity by using lagged values of the fiscal deficit, government expenditure, current account, etc. This exercise is summarized in Tables la and 2a. The rankings were done for the period 1997-1999.

Alternatively, we orthogonalized (by means of a linear regression) these variables with respect to the variables used to forecast growth. These results are presented in table $2 \mathrm{a}$ and $2 \mathrm{~b}$. Given the magnitude of Venezuela's forecast error, the rankings were done including and excluding that country from the sample. Given that we use contemporaneous variables, and we don't have 1999 data for most variables, the correlations were done for 1997 and 1998.

Summarizing the results: there is no systematic relationship between the forecast errors and any of the tested variables. Probably, the lagged current account balance is the only case where the sign is the same and the size of the coefficient hints at any significance.

\section{Rank Correlations, Table 1a and Table 2a:}

The residual rank correlations were

constructed by correlating the rankings of the VAR forecast errors (differences between the observed minus the forecasted values)with the rakings of the variables in levels at $t-1$. This was done alternatively including and excluding Venezuela in the sample.

\section{Residual Rank Correlations, Table $1 b$ and Table $2 b$ :}

The residual rank correlations were derived by running time series regressions $\# 1, \# 2$, and $\# 3$ for each country separately; the orthogonal residuals (contemporaneously uncorrelated with the error terms in the VARs) were then ranked and correlated with the rankings of the difference between the observed minus the forecasted values of the VARs of each country in period $t$.

\section{Regression \#1}

$Y_{t}=\alpha_{1}+\alpha_{2}$ embi $_{t}+\alpha_{3}$ reer $_{t}+\alpha_{4} r_{t}+\alpha_{5}$ tot $_{t}+\mu_{t}$ 
$Y_{t}=\beta_{1}+\beta_{2}$ reer $_{t}+\beta_{3} r_{t}+\beta_{4}$ tot $_{t}+\mu_{t}^{\prime}$

Regression \#3

$Y_{t}=\delta_{1}+\delta_{2} k a_{t}+\delta_{3}$ reer $_{t}+\delta_{4} r_{t}+\delta_{5} t_{0} \hat{t}_{t}+\mu{ }^{\prime}{ }_{t}$

\begin{tabular}{|c|c|c|c|c|c|c|c|}
\hline & \multicolumn{7}{|c|}{ Table 1a. Rank Correlations } \\
\hline $\begin{array}{c}\text { M2/Reserves } \\
\text { Change }\end{array}$ & $\begin{array}{c}\text { Change } \\
\text { STD/Reserves }\end{array}$ & $\begin{array}{c}\text { Budget Deficit } \\
\text { (\% to GDP) }\end{array}$ & $\begin{array}{c}\text { CAB } \\
\text { (\% to GDP) }\end{array}$ & $\begin{array}{l}\text { Change in } \\
\text { Public } \\
\text { Expenditures } \\
\text { (\% to GDP) }\end{array}$ & $\begin{array}{l}\text { Change in } \\
\text { Domestic } \\
\text { Credit } \\
\text { (\% to GDP) }\end{array}$ & $\begin{array}{l}\text { Domes } \\
\text { Credit } \\
\text { (\% to G G }\end{array}$ \\
\hline 1997 & 0.24 & 0.24 & -0.12 & 0.14 & 0.26 & -0.12 & 0.1 \\
\hline 1998 & -0.21 & -0.52 & -0.50 & -0.24 & 0.00 & -0.67 & 0.1 \\
\hline 1999 & 0.14 & 0.24 & 0.01 & 0.64 & 0.00 & 0.55 & -0. \\
\hline & & & & & & & \\
\hline
\end{tabular}

Note: Used the rankings of the difference between observed minus forecasted and the rankings of the variables in at $\mathrm{t}-1$

\begin{tabular}{|c|c|c|c|c|c|c|c|}
\hline & \multicolumn{7}{|c|}{ Table 1b. Rank Correlations } \\
\hline & $\begin{array}{c}\text { Change } \\
\text { M2/Reserves }\end{array}$ & $\begin{array}{c}\text { Change } \\
\text { STD/Reserves }\end{array}$ & $\begin{array}{c}\text { Budget } \\
\text { Deficit } \\
\text { (\% to GDP) }\end{array}$ & $\begin{array}{c}\text { CAB } \\
\text { (\% to GDP) }\end{array}$ & $\begin{array}{l}\text { Change Public } \\
\text { Expenditures } \\
\text { (\% to GDP) }\end{array}$ & $\begin{array}{l}\text { Change in } \\
\text { Domestic } \\
\text { Credit } \\
\text { (\% to GDP) }\end{array}$ & $\begin{array}{l}\text { Domestic } \\
\text { Credit } \\
\text { (\%) to }\end{array}$ \\
\hline 1997 & -0.14 & -0.14 & 0.32 & 0.71 & -0.11 & -0.43 & -0.36 \\
\hline 1998 & -0.82 & -0.29 & -0.32 & 0.88 & 0.32 & -0.50 & -0.29 \\
\hline 1999 & -0.29 & 0.04 & 0.23 & 0.46 & 0.21 & 0.32 & -0.11 \\
\hline
\end{tabular}

Note: Venezuela not included. Used the rankings of the difference between observed minus forecasted and the rankings of the variables in levels at $\mathrm{t}-1$

\begin{tabular}{|l|c|c|c|c|c|c|c|}
\hline & \multicolumn{7}{|c|}{ Table 2a. Residual Rank Correlations } \\
\hline & $\begin{array}{l}\text { Change in } \\
\text { M2/Reserves }\end{array}$ & $\begin{array}{c}\text { Change in } \\
\text { STD/Reserves }\end{array}$ & $\begin{array}{l}\text { Budget Deficit } \\
\text { (\% to GDP) }\end{array}$ & $\begin{array}{l}\text { CAB } \\
\text { (\% to GDP) }\end{array}$ & $\begin{array}{l}\text { Change } \\
\text { Public } \\
\text { Expenditures } \\
\text { (\% to GDP) }\end{array}$ & $\begin{array}{l}\text { Change in } \\
\text { Domestic } \\
\text { Credit } \\
\text { (\% to GDP) }\end{array}$ & $\begin{array}{l}\text { Domestic } \\
\text { Credit } \\
\text { (\% to GDP }\end{array}$ \\
\hline $\begin{array}{l}1997 \\
\text { Eq.1 }\end{array}$ & -0.17 & -0.52 & 0.31 & 0.76 & -0.19 & -0.10 & -0.22 \\
\hline $\begin{array}{l}\mathbf{1 9 9 8} \\
\text { Eq.1 }\end{array}$ & 0.81 & 0.19 & -0.19 & -0.62 & -0.02 & -0.05 & 0.65 \\
\hline \begin{tabular}{l}
\hline 1997 \\
Eq.2
\end{tabular} & 0.10 & 0.05 & -0.48 & 0.12 & -0.19 & -0.24 & -0.02 \\
\hline $\mathbf{1 9 9 8}$ & -0.19 & -0.36 & -0.14 & -0.52 & -0.05 & 0.14 & 0.33 \\
\hline Eq.2 & & & & & & & \\
\hline $\begin{array}{l}1997 \\
\text { Eq.3 }\end{array}$ & 0.17 & 0.17 & -0.31 & -0.17 & -0.36 & 0.07 & -0.07 \\
\hline $\begin{array}{l}1998 \\
\text { Eq.3 }\end{array}$ & -0.21 & -0.38 & -0.24 & -0.24 & -0.02 & -0.05 & 0.14 \\
\hline
\end{tabular}




\begin{tabular}{|c|c|c|c|c|c|c|c|}
\hline & & & Table 2b. Res & idual Rank C & Correlations & & \\
\hline & $\begin{array}{c}\text { Change in } \\
\text { M2/Reserves }\end{array}$ & $\begin{array}{c}\text { Change in } \\
\text { STD/Reserves }\end{array}$ & $\begin{array}{c}\text { Budget } \\
\text { Deficit } \\
\text { (\% to GDP) }\end{array}$ & $\begin{array}{c}\text { CAB } \\
\text { (\% to GDP) }\end{array}$ & $\begin{array}{l}\text { Change Public } \\
\text { Expenditures } \\
\text { (\% to GDP) }\end{array}$ & $\begin{array}{l}\text { Change in } \\
\text { Domestic } \\
\text { Credit } \\
\text { (\% to GDP) }\end{array}$ & $\begin{array}{l}\text { Domestic } \\
\text { Credit } \\
\text { (\% to GDP) }\end{array}$ \\
\hline $\begin{array}{l}1997 \\
E q .1\end{array}$ & 0.14 & -0.29 & 0.00 & 0.64 & $0 . \overline{18}$ & 0.36 & 0.36 \\
\hline $\begin{array}{l}1998 \\
\text { Eq.1 }\end{array}$ & 0.79 & -0.21 & 0.21 & -0.43 & 0.07 & 0.00 & 0.68 \\
\hline $\begin{array}{l}1997 \\
\text { Eq.2 }\end{array}$ & -0.29 & -0.07 & -0.25 & 0.68 & -0.04 & 0.29 & -0.54 \\
\hline $\begin{array}{l}1998 \\
\text { Eq.2 }\end{array}$ & -0.43 & $-0 . \overline{39}$ & -0.11 & -0.29 & 0.07 & 0.07 & 0.00 \\
\hline $\begin{array}{l}1997 \\
\text { Eq.3 }\end{array}$ & -0.25 & 0.04 & 0.00 & 0.25 & -0.07 & 0.61 & -0.39 \\
\hline $\begin{array}{l}1998 \\
\text { Eq.3 }\end{array}$ & -0.46 & -0.29 & 0.00 & 0.14 & -0.29 & 0.04 & -0.11 \\
\hline
\end{tabular}

Note Venezuela not included.

Independent Variables: Definitions and sources.

EMBI: Emerging Market Bond Index (J.P. Morgan, Inc.)

REER: Real Effective Exchange Rate

The source was the IFS database, IMF.

r: Real interest rate (ex-post).

$x=\left(\left(1+i_{\text {nom }} / 100\right) /(1+\pi / 100)-1\right)^{*} 100$

where

$\mathrm{i}_{\text {nom }}=$ nominal interest rate

$\pi=$ inflation.

Money Market Rates were used in the cases of Argentina, Brazil, and Mexico. Deposit rates in the case of Chile, and discount rates in the cases of Colombia, Ecuador, Peru, and Venezuela. The source was IMF, IFS database.

Terms of Trade: Index, 1990 $=100$. Source Inter-American Development Bank Statistics and Quantitative Analysis Unit.

Dependent Variables: Definitions and sources.

-M2: Money plus quasimoney (IMF,IFS: lines 34 and 35)

-Reserves: International Reserves minus gold (IMF, IFS: line 1I.d)

-Short Term Debt: Liabilities to banks due within a year (Joint BIS, IMF, OECD, World Bank Statistics. 
-Budget Deficir (\%to GDP): Non-financial public sector balance (Domestic National Sources and World Bank staff estimates)

Current Account Balance (\% to GDP): Source: Domestic national sources and World Bank staff estimates.

Change in Public Expenditures: Public Expenditures are in percentages to GDP. Non-financial public sector in the cases of Argentina, Chile, Colombia, Ecuador, Mexico, and Venezuela. Central government in the cases of Brazil and Peru. In the cases of Argentina (1980-82) and Venezuela (1980-83), changes in central government expenditures were used as proxies for the years because of the lack of data on nonfinancial public sector expenditures during those years. For Brazil (1994-98), National Treasury Performance Summary was used due to lack of data on central government expenditures during that period of time.

Domestic Credit: Private domestic credit. The source was iDB Statistical and Quantirative Analysis Unit. Domestic Credit data was used from the IMF IFS whenever data was missing from the IDB database. 


\section{Appendix 7 \\ Model Selection Issues- Spreads or Capital Flows?}

This appendix presents details of the two alternative model selection procedures, the nested hypothesis approach and the non-nested tests. The first approach follows Gourieroux and Monfort( 1997), while the second one is based mainly on Pesaran and Pesaran (1997) and Pesaran and Weeks (1999) The first approach, based on a general to specific modeling strategy, seeks to determine the validity of a set of parametric restrictions by which one model (the restricted one including only spreads) can be derived from a more general one. This testing strategy verifies the informational value of one variable (capital flows), conditional on the other one (spreads) being included. Tables below show different statistics for the amplified VAR (VAR-A) and the restricted VAR including spreads only and capital flows only. In every case we are unable to reject the restriction that the capital flows should be excluded, given that the spreads were included ${ }^{30}$. However, given that our interest was focused on output, we performed some tests on the output equation only, but still in the nested hypothesis framework. That is, given that spreads were included, we performed a Wald Test to verify the restriction that the capital flows coefficients were zero: in Brazil, Colombia and Mexico we reject the statistical significance of the restriction, implying that in these countries the capital flows proxy las additional information not contained in the spreads ${ }^{31}$.

However, repeating the same exercise to test the informational value of spreads, conditional on the capital flows being included, similar results emerge in the sense that the restricted model is selected, but this time including capital flows. The single equation Wald Test on the restriction that the spreads coefficients are equal to zero is rejecte $\downarrow$ for all the cases, except for Ecuador, Peru and Venezuela. This implies that in the major countries of the region, spreads are informative for output growth even after capital flows have been accounted for.

The second approach we used to verify potential problems in our model selection consisted of the Nonnested hypothesis testing (Pesaran and Weeks, 1999). Based on several tests (Pesaran \& Pesaran, 1997) we examine the hypothesis that we are dealing with "competing" models and one has to be chosen over the other. Tables below summarize the results for each country, considering that Model 1 includes the spreads variable and Model 2 includes the capital flows variable. Some ambiguity emerges because the tests point in different direction and there's no rule as to which test is more powerful, except for some small-sample properties of some of them. Based on these considerations, we conclude that in Colombia, Mexico, Peru and Ecuador, the model with capital flows seems to better fit the data; Chile is a borderline case.

\section{A) Nested Hypothesis Testing}

This section shows the VAR system statistics (maximised loglikelihood and Schwarz) and single (output) equation Wald Tests to test the restrictions on the coefficients on the output equation. All theVARs were estimated with identical number of lags (12), except in Argentina where the amplified model was run with a shorter lag length (6) due to data restrictions.

\footnotetext{
${ }^{30}$ Note that the Loglikelihood function (LLF) of the restricted model is always superior to that of the unrestricted model. Additionally, the likelihood ratio statistic, computed as twice the difference between the unrestricted and restricted LLF (Gourieroux and Monfont, 1997) is generally a negative number leading to the inability to reject the restriction. The Schwarz criterion is also minimized in the restricted version always.

${ }^{31}$ These three countries account for $65 \%$ of the aggregate GDP of the sample countries. Probably this is why in the regional Panel estimation of the single output equation the flows variable turned out to be significant.
} 


\begin{tabular}{|c|c|c|c|}
\hline \multicolumn{5}{|c|}{$\begin{array}{c}\text { VAR statistics for the Amplified VAR (VAR-A) and the Restricted Versions: only spreads (VAR-RS) and } \\
\text { only capital flows (VAR-RK) }\end{array}$} \\
\hline & VAR-A & VAR-RS & VAR-RK \\
& (Includes SPR and KFL) & (Restriction: KFLO=0) & (Restriction: SPR=0) \\
\hline ARG-Log Likelihood & -514.4 & -265.8 & -371.1 \\
Schwarz & 37.7 & 23.0 & 26.7 \\
\hline BRA Log Likelihood & -777.1 & -438.5 & -77.6 \\
Schwarz & 42.0 & 26.8 & 18 \\
\hline CHL Log Likelihood & -381.0 & -189.9 & -231.0 \\
Schwarz & 32.5 & 20.8 & 21.8 \\
\hline COL Log Likelihood & -459.0 & -361.0 & -416 \\
Schwarz & 34.4 & 24.9 & 26.3 \\
\hline ECU Log Likelihood & -416.1 & -244.0 & -168.5 \\
Schwarz & 33.3 & 22.1 & 20.3 \\
\hline MEX Log Likelihood & -137.9 & 196.4 & -45.9 \\
Schwarz & 26.6 & 11.5 & 17.3 \\
\hline PER Log Likelihood & -621.8 & -426.3 & -468.6 \\
Schwarz & 38.3 & 26.5 & 27.5 \\
\hline VEN Log Likelihood & -902.4 & -622.2 & -641.6 \\
Schwarz & 45.1 & 31.2 & 31.7 \\
\hline
\end{tabular}

\begin{tabular}{|l|c|c|c|c|}
\hline \multicolumn{5}{|c|}{ Wald Test Statistics for Hypothesis Testing in the Output Equation of the VAR } \\
\hline & \multicolumn{2}{|c|}{ Hypothesis: KFL coefficients $=0$} & \multicolumn{2}{c|}{ Hypothesis: SPR coefficients=0 } \\
\hline & Statistic (p-value) & Decision & Statistic (p-value) & Decision \\
\hline ARG & $8.6(.38)$ & Unable to reject & $15.3(.05)$ & Reject \\
\hline BRA & $28.0(.01)$ & Reject & $31.7(.01)$ & Reject \\
\hline CHL & $17.2(.14)$ & Unable to reject & $25.3(.01)$ & Reject \\
\hline COL & $39.0(.00)$ & Reject & $30.5(.01)$ & Reject \\
\hline ECU & $12.7(.39)$ & Unable to reject & $8.9(.71)$ & Unable to reject \\
\hline MEX & $20.4(.06)$ & Reject & $34.2(.00)$ & Reject \\
\hline PER & $17.3(.14)$ & Unable to reject & $14.5(.27)$ & Unable to reject \\
\hline VEN & $3.5(.99)$ & Unable to reject & $1.8(1.0)$ & Unable to reject \\
\hline
\end{tabular}

B) Non-nested hypothesis tests

These tests are summarized in Pesaran \& Pesaran (1997) and thoroughly discussed in Pesaran and Weeks (1999). Here we will only list the tests and the original authors, referring the reader to the above referenced literature for more details.

N Test- Cox test derived in Pesaran (1974)

NT-test- derived in Godfrey and Pesaran (1983)

W-test Wald type test proposed in Godfrey and Pesaran (1983)

J-test- Proposed by Davidson and McKinnon (1981)

JA-test- Due to Fisher and McAleer (1981)

Encompassing test-Mizon and Richard (1986) 


\begin{tabular}{|c|c|c|}
\hline & $\mathrm{M} 1$ against $\mathrm{M} 2$ & M2 aganst M1 \\
\hline N-Test & $-3.34(.001)$ & $-10.83(000)$ \\
\hline NT-test & $.087(.931)$ & $-1.75(079)$ \\
\hline W-test & $.087(.931)$ & $-1.62(.105)$ \\
\hline J Test & $1.94(.052)$ & $3.405(000)$ \\
\hline JA test & $.171(.864)$ & $.205(0.84)$ \\
\hline Encompassing & $.805(.555)$ & $2.21(078)$ \\
\hline Schwarz test of M1 vs. M2 & \multicolumn{2}{|c|}{5.68 favors $\mathrm{MI}$} \\
\hline \multicolumn{3}{|c|}{$\begin{array}{l}\text { Tests for the Non- Nested Hypothesis of the Model with Spreads (Model 1) against the Model with Capital } \\
\text { Flows (Model 2)- Brazil }\end{array}$} \\
\hline & M1 against $\mathrm{M} 2$ & M2 against $M$ \\
\hline $\mathrm{N}$ - Test & $-6.75(.000)$ & $-10.49(.000)$ \\
\hline NT-test & $-.085(.932)$ & $-.738(.460)$ \\
\hline W-test & $-.084(.933)$ & $-.690(.490)$ \\
\hline J Test & $3.147(.002)$ & $401(.000)$ \\
\hline JA test & $-.269(.788)$ & $.831(.406)$ \\
\hline Encompassing & $2.33(.094)$ & $2.64(.067)$ \\
\hline Schwarz test of M1 vs. M2 & \multicolumn{2}{|c|}{3.86 favors $\bar{M}$} \\
\hline
\end{tabular}

Tests for the Non- Nested Mypothesis of the Model with Spreads (Model 1) against the Mode with Capital Flows (Model 2)- Chile

\begin{tabular}{|l|l|l|}
\hline & \multicolumn{1}{|c|}{ M1 against M2 } & \multicolumn{1}{c|}{$\mathrm{M} 2$ against M1 } \\
\hline N- Test & $.465(.642)$ & $-13.77(000)$ \\
\hline NT-test & $1.503(.133)$ & $-.031(.975)$ \\
\hline W-test & $1.777(.076)$ & $-.031(.975)$ \\
\hline J Test & $1.836(.066)$ & $5.05(.000)$ \\
\hline JA test & $-3.65(.000)$ & $.056(.955)$ \\
\hline Encompassing & $1.43(289)$ & $2.105(.124)$ \\
\hline Schwarz test of M1 vs. M2 & 10.79 favors M1 & \\
\hline
\end{tabular}

Tests for the Non- Nested Hypothesis of the Model with Spreads (Model 1) against the Modei with Capital Flows (Model 2)- Colombiri

\begin{tabular}{|l|l|l|}
\hline & \multicolumn{1}{|c|}{ M1 against M2 } & \multicolumn{1}{c|}{ M2 against M1 } \\
\hline N- Test & $-11.11(.000)$ & $-5.29(.000)$ \\
\hline NT-test & $-1.26(.208)$ & $-.244(.807)$ \\
\hline W-test & $-1.11(.266)$ & $-.238(.812)$ \\
\hline J Test & $6.51(.000)$ & $4.50(.000)$ \\
\hline JA test & $.163(.871)$ & $-.938(.348)$ \\
\hline Encompassing & $3.25(.035)$ & $2.54(.074)$ \\
\hline Schwarz test of M1 vs. M2 & -7.92 favors M2 & \\
\hline
\end{tabular}


Tests for the Non- Nested Hypothesis of the Model with Spreads (Model 1) against the Model with Capital Flows (Model 2)- Ecuador

\begin{tabular}{|l|l|l|}
\hline & \multicolumn{1}{|c|}{ M1 against M2 } & \multicolumn{1}{c|}{ M2 against M1 } \\
\hline N- Test & $-11.33(.000)$ & $-8.48(.000)$ \\
\hline NT-test & $-.677(.498)$ & $-.218(.827)$ \\
\hline W-test & $-.631(.528)$ & $-.214(.830)$ \\
\hline J Test & $4.09(.000)$ & $3.31(.001)$ \\
\hline JA test & $.662(.508)$ & $.986(.324)$ \\
\hline Encompassing & $1.06(.472)$ & $.739(.695)$ \\
\hline Schwarz test of M1 vs. M2 & -7.64 favors M2 & \\
\hline
\end{tabular}

Tests for the Non- Nested Hypothesis of the Model with Spreads (Model 1) against the Model with Capital Flows (Model 2)- Mexico

\begin{tabular}{|l|l|l|}
\hline & \multicolumn{1}{|c|}{ M1 against M2 } & \multicolumn{1}{c|}{ M2 against M1 } \\
\hline N- Test & $-14.41(.000)$ & $-1.02(.31)$ \\
\hline NT-test & $-1.95(.051)$ & $.716(.474)$ \\
\hline W-test & $-1.62(.106)$ & $.773(.44)$ \\
\hline J Test & $5.67(.000)$ & $1.793(.073)$ \\
\hline JA test & $2.88(.004)$ & $-1.42(.155)$ \\
\hline Encompassing & $2.85(.053)$ & $1.69(.205)$ \\
\hline Schwarz test of M1 vs. M2 & -15.62 favors M2 & \\
\hline
\end{tabular}

Tests for the Non- Nested Hypothesis of the Model with Spreads (Model 1) against the Model with Capital Flows (Model 2)- Peru

\begin{tabular}{|l|l|l|}
\hline & \multicolumn{1}{|c|}{ M1 against M2 } & \multicolumn{1}{c|}{ M2 against M1 } \\
\hline N- Test & $-16.80(.000)$ & $-5.81(.000)$ \\
\hline NT-test & $-.657(.511)$ & $.109(.913)$ \\
\hline W-test & $-.621(.535)$ & $.111(.912)$ \\
\hline J Test & $4.796(.000)$ & $3.64(.000)$ \\
\hline JA test & $-.034(.973)$ & $-1.203(.229)$ \\
\hline Encompassing & $1.44(.286)$ & $1.209(.387)$ \\
\hline Schwarz test of M1 vs. M2 & -4.44 favors M2 & \\
\hline
\end{tabular}

Tests for the Non- Nested Hypothesis of the Model with Spreads (Model 1) against the Model with Capital Flows (Mode1 2)- Venezuela

\begin{tabular}{|l|l|l|}
\hline & \multicolumn{1}{|c|}{ M1 against M2 } & \multicolumn{1}{c|}{ M2 against M1 } \\
\hline $\mathrm{N}-$ Test & $-7.21(.000)$ & $-3.59(.000)$ \\
\hline $\mathrm{N}$ T-test & $.53(.596)$ & $1.00(.315)$ \\
\hline W-test & $.567(.571)$ & $1.11(.263)$ \\
\hline J Test & $2.47(.014)$ & $1.61(.545)$ \\
\hline JA test & $.698(.485)$ & $.604(.545)$ \\
\hline Encompassing & $.296(.975)$ & $.152(.998)$ \\
\hline Schwarz test of M1 vs. M2 & -5.67 favors M2 & \\
\hline
\end{tabular}





\section{Policy Research Working Paper Series}

Title
WPS2314 Technological Leadership and Foreign Investors' Choice of Entry Mode

\section{Author}

WPS2317 Trade Negotiations in the Presence of Keiko Kubota Network Externalities

WPS2318 Regulatory Reform, Competition, and Innovation: A Case Study of the Mexican Road Freign Industry

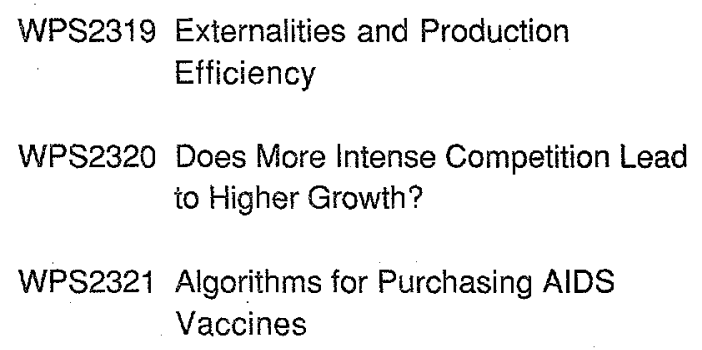

WPS2320 Does More Intense Competition Lead to Higher Growth?

WPS2321 Algorithms for Purchasing AIDS Vaccines
WPS2322 Self-Targeted Subsidies: The Distributional Impact of the Egyptian Food Subsidy System
WPS2323 Globalization and Firms' Financing Choices: Evidence from Emerging Economies

WPS2324 Give Growth and Macroeconomic Stability in Russia a Chance: Harden Budgets by Eliminating Nonpayments

WPS2325 Banking Systems Around the Globe: Do Regulation and Ownership Affect Performance and Stability?

WPS2326 How Urban Concentration Affects Economic Growth

WPS2327 How the Republic of Korea's Financial Structure Affects the Volatility of Four Asset Prices
Beata K. Smarzynska

Alejandro Jadresic

Emanuela Galasso

Martin Ravallion

\section{Date}

Contact for paper

L. Tabada 36896

April 2000

M. Salehi 37157

April 2000

P. Sader 33902

April 2000

L. Tabada 36896

April 2000

H. Sladovich

Aydin Hayri

37698

Pablo Ibarra

Gunnar S. Eskeland

April 2000

H. Sladovich 37698

April 2000

H. Sladovich Aydin Hayri

David Bishai

Maria K. Lin

C. W. B. Kiyonga

Richard H. Adams, Jr. April 2000

M. Coleridge-Taylor

Sergio Schmukier

Esteban Vesperoni

Brian Pinto

Vladimir Drebentsov

Alexander Morozov

James R. Barth

Gerard Caprio, Jr.

Ross Levine

Vernon Henderson

Hong G. Min

Jong goo Park
April 2000 33704

April 2000

E. Khine 37471

April 2000

37698

P. Sader 33902

H. Makarenko 87832

April 2000

A. Yaptenco 31823

April 2000

R. Yazigi 37176

April 2000

P. Rathan-Raj 33705 
Policy Research Working Paper Series

Title

WPS2328 Social Transfers and Social Assistance: An Empirical Analysis

Using Latvian Household Survey Data

WPS2329 Improving Russia's Policy on Foreign Direct Investment

WPS2330 Reducing Structural Dominance and Entry Barriers in Russian Industry

WPS2331 Competition, Corporate Governance, Harry G. Broadman and Regulation in Central Asia: Uzbekistan's Structural Reform Challenges

WPS2332 Financial Intermediary Distress in the Republic of Korea: Small Is Beautiful?
Author

Branko Milanovic

Joel Bergsman

Harry G. Broadman

Vladimir Drebentsov

Harry G. Broadman

Paola Bongini Giovanni Ferri Tae Soo Kang
Date

May 2000

S. Craig 33160

May 2000

S. Craig 33160

Contact

for paper

P. Sader 33902

S. Craig 33160

May 2000

K. Labrie 31001 